Universidade de São Paulo

Faculdade de Ciências Farmacêuticas de Ribeirão Preto

\title{
Avaliação do efeito da isoflavona sobre o epitélio cérvico-vaginal e sintomas da menopausa
}

Edna Talarico Rodrigues 


\section{Avaliação do efeito da isoflavona sobre o epitélio cérvico-vaginal e sintomas da menopausa}

Dissertação apresentada ao Programa de PósGraduação em Biociências Aplicadas à Farmácia, como requisito parcial à obtenção de Título de Mestre em Biociências Aplicadas à Farmácia, Área de Concentração: Biociências Aplicadas á Farmácia.

Orientada: Edna Talarico Rodrigues

Orientadora: Prof. Dra. Maria Regina Torqueti Toloi 
Rodrigues, Edna Talarico

Avaliação do efeito da isoflavona sobre o epitélio cérvico-vaginal e sintomas da menopausa. Ribeirão Preto, 2006.

121 p.: il. , $30 \mathrm{~cm}$.

Dissertação, apresentada à Faculdade de Ciências Farmacêuticas de Ribeirão Preto/USP - Área de Concentração: Biociências Aplicadas á Farmácia.

Orientadora: Dra ${ }^{\mathrm{a}}$. Maria Regina Torqueti Toloi.

1. Menopausa. 2.Isoflavona. 3.Citologia cérvico-vaginal. 4. Sintomas da menopausa. 
Este trabalho foi realizado no Laboratório de Citologia Clínica da Faculdade de Ciências Farmacêuticas de Ribeirão Preto/USP e contou com apoio financeiro da FAPESP. CAPES e Pró-reitoria de pós-graduação da USP. 


\section{FOLHA DE APROVAÇÃO}

Autora: Edna Talarico Rodrigues

Título: Avaliação do efeito da isoflavona sobre o epitélio cérvico-vaginal e sintomas da menopausa

Dissertação de Mestrado apresentada ao Programa de Pós-Graduação em Ciências Farmacêuticas, para a obtenção do título de Mestre em Biociências Aplicadas à Farmácia, Área de Concentração Biociências Aplicadas à Farmácia.

Prof. Dr.

Instituição

Prof. Dr.

Instituição

Prof. Dr.

Instituição

Trabalho defendido e aprovado pela Comissão Julgadora em /2007. 


\section{DEDICATÓRIA}

"Existem pessoas em nossas vidas que nos deixam felizes pelo simples fato de terem cruzado o nosso caminho. Algumas percorrem ao nosso lado, vendo muitas luas passarem, mas outras apenas vemos entre um passo e outro. A todas elas chamamos de amigo. Há muitos tipos de amigos. Talvez cada folha de uma árvore caracterize um deles. Os primeiros que nascem do broto é o amigo pai e a amiga mãe. Mostram o que é ter vida".

Depois vem o amigo irmão, com quem dividimos o nosso espaço para que ele floresça como nós. Passamos a conhecer toda a família de folhas, a qual respeitamos e desejamos o bem. O destino ainda nos apresenta outros amigos, os quais não sabíamos que iam cruzar o nosso caminho. Muitos desse são designados amigos do peito, do coração. São sinceros, são verdadeiros. Sabem quando não estamos bem, sabem o que nos faz feliz...

Mas também há aqueles amigos por um tempo, talvez umas férias ou mesmo um dia ou uma hora. Esses costumam colocar muitos sorrisos na face, durante o tempo que estamos por perto.

Falando em perto, não podemos nos esquecer dos amigos distantes, que ficam nas pontas dos galhos mas que quando o vento sopra, aparecem novamente entre uma folha e outra.

O tempo passa, o verão se vai, o outono se aproxima, e perdemos algumas de nossas folhas. Algumas nascem num outro verão e outras permanecem por muitas estações. O que nos deixa mais felizes é quando as folhas que caíram continuam por perto, continuam alimentando as nossas raízes com alegria. Lembranças de momentos maravilhosos enquanto cruzavam o nosso caminho. Desejo a você, folha da minha árvore, paz, amor, saúde, sucesso, prosperidade... Hoje e sempre...

Simplesmente porque cada pessoa que passa em nossa vida é única. Sempre deixa um pouco de si e leva um pouco de nós. Há os que levaram muito, mas não há os que não deixaram nada. Esta é a maior responsabilidade de nossa vida e a prova evidente de que duas almas não se encontram por acaso.

Obrigado pela oportunidade de te conhecer....."

(Família Mobílio de Lima - 1.10.2006-página da Internet)

Ao Bruno, que partiu sem avisar, que não nos deu a chance de passar a limpo tanto que ficou mal resolvido, tantos sonhos que faltou viver, tantas palavras que não foram ditas, tantos planos deixados para depois, tantos desafios para superarmos juntos...pela pouca noção e controle que temos do irrisório e minguado "tempo", quando imaginamos que compartilhamos um amor, que ele é eterno e infinito, mesmo que não perdure... Qualquer maneira de amar vale a pena.... Um forte abraço.

Onde quer que você esteja, levarei comigo, com carinho, tua cálida lembrança!!! 


\section{AGRADECIMENTOS}

Embora uma dissertação seja, pela sua finalidade acadêmica, um trabalho individual, há contributos de natureza diversa, que não podem e nem devem deixar de ser realçados. A realização desta dissertação contou com a colaboração, consciente ou inconsciente, de um conjunto amplo de familiares, colegas, e todos especialmente, amigos, aos quais agradeço sinceramente.

Agradeço, em primeiro lugar, a Deus, que dispensa comentários e esteve ao meu lado em todos os momentos não me deixando fraquejar.

A minha mãe Iracema e a meu pai Edgard, que sempre confiaram em meus sonhos, mesmo nos mais loucos, e me ensinaram a acreditar que é possível realizá-los, além de me mostrarem que trabalho duro, perseverança e honestidade são as ferramentas ideais para atingirmos nossas metas.

Aos meus filhos, Giuliano e Giovanna, pela compreensão e ternura sempre manifestadas apesar do 'débito' de atenção; e pela excitação e orgulho com que sempre reagiram aos resultados académicos da 'mãe/colega'. Espero que o entusiasmo, seriedade e empenho que ponho no trabalho lhes possa servir de estímulo para fazerem sempre 'mais e melhor'.

Às voluntárias que participaram deste estudo, sem elas ele ainda seria um projeto, no papel. A elas eu devo, além dos resultados, a experiência de suas vidas, suas dores, inseguranças, soluções para seus problemas e a certeza de uma troca tremendamente enriquecedora.

A Prof. Dra. Maria Regina Torqueti Toloi que logo me abriu além da porta do laboratório também a do seu coração de "mãe", do que me encaminharia para o estágio em citologia e para tema tratado nesta dissertação. Pela disponibilidade revelada ao longo deste nosso tempo juntas, pelos esforços empenhados, pelas críticas e sugestões relevantes feitas durante a orientação. 
Ao Dr. Sílvio Antônio Franceschini, pelo auxílio e acompanhamento das pacientes, além da disponibilidade e respostas 'à velocidade da luz', sempre acompanhadas de comentários estimulantes e sensatos.

À Prof Regina Célia Cândido pelo acolhimento e apoio sempre oferecido.

A Marlise, que guiou meus passos durante esta caminhada.

À Karina pelo carinho com que me ajudou a vencer o desafio de digitar esta dissertação. À Elaine, à Priscila, à Giovanna, à Patrícia, também pela ajuda neste caminho.

Aos amigos da pós-graduação Michele, Helder, Daniel, Juliana, Lílian, Alex, Carla, Rafael, Natalia, Renata, Joseane e especialmente a Dannyelle, minha parceira neste projeto de pesquisa.

À Maria Emília, da Bacteriologia e todos os funcionários do Laboratório de Análises Clínicas (LAC) da FCFRP-USP.

Aos vigias do prédio sempre solidários e atenciosos.

Aos residentes e médicos do Posto de Saúde Escola Cuiabá que atenderam carinhosamente nossas voluntárias.

Aos médicos, funcionários, estagiários dos Serviços de Saúde e qualidade de vida, que cuidaram da minha saúde, para que eu pudesse chegar viva até aqui.

À Marivone, Joana, Sebastiana, Océlia, Cristina, Lenita, Leila, Sílvia, Cecília, equipe do arquivo e da secretaria, do Posto de Saúde Escola Cuiabá pela grande colaboração no estudo.

"É muito difícil agradecer a todos sem esquecer, inevitavelmente, de alguém, mas aos que esqueci, especialmente os que vão continuar no anonimato, meu pedido de perdão e meus agradecimentos sinceros!" 


\section{RESUMO}

A menopausa é conseqüência da falência ovariana, caracterizada pela queda na produção de estrógenos, podendo causar na mulher vários sintomas e condições patológicas como vaginite atrófica, osteoporose e doençsa cardiovasculares. A terapia estroprogestiva é largamente prescrita na pós-menopausa, no entanto existem freqüentes efeitos colaterais e contra-indicações, inclusive possibilidade de aumento do câncer de mama. Devido a toda esta polêmica as terapias alternativas para combaterem os sintomas da menopausa estão largamente sendo exploradas, neste contexto cita-se os fitohormônios. A isoflavona é um deles obtido de várias plantas e mais usualmente da soja, que possui na sua molécula uma estrutura fenólica que se liga aos receptores de estrogênio e exerce um efeito estrogênico. Neste estudo enfocando a isoflavona, extraída da soja Glycine max, para o tratamento dos sintomas da menopausa, avaliou-se o efeito desse composto sobre a maturação do epitélio cérvico-vaginal e microbiota vaginal. Para isto propô-se um estudo randomizado, duplo cego, placebo controlado do qual participaram 49 voluntárias. Um grupo de 23 mulheres recebeu 1 cápsula/dia de $40 \mathrm{mg}$ de caseína de leite, constituindo o grupo placebo e o outro grupo de 26 mulheres tratadas com 1 cápsula/dia de $40 \mathrm{mg}$ de isoflavona. Amostras de urina e secreção vaginal para colpocitograma, colpocitograma com coleta úmida, bacterioscopia foram colhidas antes do início e ao término do tratamento. Foram determinados índice de maturação (I.M.) e valor de maturação (V.M.) pela técnica da citologia hormonal. O estudo da microbiota foi avaliado por exame direto a fresco e bacterioscopia de Gram. As mulheres participantes do estudo forneceram dados através de entrevistas mensais, antes do início e após o término do estudo, respondendo a questionários sobre queixas, sintomas, história da vida sexual, percepção da menopausa, estado de saúde e questões sócio demográficas. A avaliação destes dados aparece no índice de Kuppermann, nas maiores queixas e melhoras mais evidentes das mulheres tratadas com isoflavona. A avaliação do I.M. resultou no grupo tratado com isoflavona em redução significativa das células parabasais $(P=0,003)$ no colpocitograma tradicional, em aumento significativo das células superficiais cianofílicas $(P=0,006)$ e tendência de aumento das células superficiais eosinofílicas $(P=0,18)$. No colpocitograma obtido por coleta úmida houve diminuição significativa das células parabasais $(P=0,004)$, aumento significativo na porcentagem de células superficiais cianofílicas $(P=0,008)$ e tendência de aumento das células superficiais eosinofílicas $(P=0,18)$. No urocitograma houve redução significativa de células parabasais $(P=0,008)$, aumento significativo na porcentagem de células superficiais cianofílicas $(P=0,013)$ e aumento das células superficiais eosinofílicas $(P=0,002)$. No grupo placebo não se observou variação significativa nos índices acima mencionados. $O$ V.M. no grupo tratado com isoflavona apresentou aumento significativo $(P=0,007)$ no colpocitograma tradicional, colpocitograma, obtido por coleta úmida $(P=0,004)$; e no urocitograma $(P=0,0008)$. No grupo placebo houve diminuição significativa $(P=0,02)$ para este índice. Após o tratamento pela isoflavona houve aumento significativo de bacilos de Döederlein ( $P=0,005)$, diminuição significativa de $19,3 \%$ nos casos de vaginose bacteriana (índice de Nugent) e diminuição de outros agentes microbiológicos patogênicos. Houve diminuição dos sintomas da menopausa após o tratamento com isoflavona, também se observou diminuição das queixas após o tratamento com placebo. 


\section{ABSTRACT}

The lack of estrogens characterizes postmenopausal condition and is associated with pathological conditions and symptoms, including atrophic vaginites, osteoporosis and cardiovascular disease. Hormone replacement therapy is recommended for postmenopausal women but there are contraindications and side effects. There are many alternative therapy researches in order to alleviate these symptoms. Soy isoflavone has hormonal effects in postmenopausal women, by binding a common phenolic structure to estrogens receptors. The aim of this study focusing isoflavone, extracted from soy beans Glycine max, was to evaluate the effects of isofavone on vaginal cytology, vaginal maturation index (M.I.), maturation value (M.V.), vaginal microbiota and menopausal symptoms. This study involved 49 postmenopausal women, a randomized double blind placebo controlled. The first group of 23 women was treated with $40 \mathrm{mg} /$ day capsule of placebo (caseyne) and the second group of 26 women was treated with $40 \mathrm{mg} /$ day capsule of isoflavone. Urine and vaginal samples for 3 slides: colpocytogram, wet sample colpocytogram, Gram-stained smears was taken at baseline and after treatment in order to determine M.I., M.V., vaginal microbiological findings and colpocytologic findings. Study participants answered an in-person interview with questions in order to determine menopausal symptoms, complains, menopause perception, sexual life, general health to determine, for instance the Kuppermann menopausal index (KMI) at baseline, every month and after six-months of treatment. The M.I. from traditional colpocytogram reduced significantly the parabasal cells $(P=0,003)$, increased significantly the percentage of Superficial Cianophilic cells $(P=0,006)$, there was a tendence of increasing the Superficial Eosinofilic cells $(P=0,18)$. From wet sample colpocytogram, similar results were obtained: reduced significantly the parabasal cells $(P=0,004)$, increased significantly the percentage of Superficial Cianophilic cells $(P=0,008)$ there was a tendence of increasing the Superficial Eosinofilic cells $(P=0,18)$.. In urocytogram, the results obtained were: reduced significantly the parabasal cells $(P=0,008)$, increased significantly the percentage of Superficial Cianophilic cells $(P=0,013)$, increase of Superficial Eosinofilic cells $(P=0,002)$. For placebo group there were no significative changes. The Maturation Value, M.V. increased significtively $(P=0,007)$ in traditional colpocytogram; in wet sample colpocytogram $(P=0,004)$ and in urocytogram $(P=0,0008)$, comparing with placebo was observed significant decrease $(P=0,02)$ for M.V. After treatment with isoflavone there was significative increase of Döederlein bacillus $(P=0,005)$, decrease of $19,3 \%$ in cases of bacterial vaginosis (Nugent score) and decrease of others pathogenic microbial agents. The symptoms decreased significatively in woman treated with placebo and decreased significatively in women treated with isoflavone. 


\section{LISTA DE FIGURAS}

FIGURA 1 Representação esquemática do controle hormonal do sistema reprodutivo feminino

FIGURA 2 Representação esquemática do controle hormonal do ciclo menstrual.

FIGURA 3 Estrutura dos principais hormônios ovarianos - 17ß-estradiol (A) e progesterona (B).

FIGURA 4 Respresentação esquemática do epitélio pluriestratificado pavimentoso não ceratinizado da vagina e ectocérvice, na mulher em idade reprodutiva

FIGURA 5 Microbiota Vaginal bacteriana, em esfregaços corados pelo método de Gram: A e B flora vaginal normal, C e D flora vaginal intermediária e E e F, vaginose bacteriana.

FIGURA 6 Tipos celulares encontrados no epitélio plurestratificado pavimentoso não ceratizado de mulheres em menacme.

FIGURA 7 Representação esquemática da produção hormonal da pré e pós menopausa

FIGURA 8 Representação esquemática da mucosa vaginal da pré e pósmenopausa

FIGURA 9 Esfregaço vaginal do tipo atrófico, característico da menopausa e da pósmenopausa

FIGURA 10 Estrutura química dos metabólitos das isoflavona de soja, comparados com o $17 \beta$-estradiol.

FIGURA 11 Característica das pacientes.

FIGURA 12 Representação gráfica dos tipos celulares do I.M. extraídos do colpocitograma de mulheres antes e após o tratamento com 40 $\mathrm{mg} /$ dia de isoflavona e $40 \mathrm{mg} /$ dia de caseína, durante 24 semanas

FIGURA 13 Representação gráfica dos I.P., I.E. e Valor de V.M. extraídos do colpocitograma das mulheres antes e após o tratamento com 40 $\mathrm{mg} / \mathrm{dia}$ de isoflavona e $40 \mathrm{mg} / \mathrm{dia}$ de caseína, durante 24 semanas 
FIGURA 14 Representação gráfica dos tipos celulares do I.M. extraídos do colpocitograma obtido da secreção vaginal para exame direto a fresco (coleta úmida) das mulheres antes e após o tratamento com $40 \mathrm{mg} / \mathrm{dia}$ de isoflavona e $40 \mathrm{mg} / \mathrm{dia}$ de caseína, durante 24 semanas.

FIGURA 15 Representação gráfica do I.P., I.E. e V.M. extraídos do colpocitograma obtido por coleta úmida das mulheres antes e após o tratamento com $40 \mathrm{mg} / \mathrm{dia}$ de isoflavona e $40 \mathrm{mg} / \mathrm{dia}$ de caseína, durante 24 semanas

FIGURA 16 Representação gráfica dos tipos celulares do I.M extraídos do Urocitograma das mulheres antes e após o tratamento com 40 $\mathrm{mg} / \mathrm{dia}$ de isoflavona e $40 \mathrm{mg} / \mathrm{dia}$ de caseína, durante 24 semanas

FIGURA 17 Representação gráfica do I.P., I.E. e V.M. do extraídos do urocitograma das mulheres antes e após o tratamento com 40 $\mathrm{mg} / \mathrm{dia}$ de isoflavona e $40 \mathrm{mg} / \mathrm{dia}$ de caseína, durante 24 semanas.

FIGURA 18 Representação gráfica da bacterioscopia da secreção vaginal das mulheres antes e após o tratamento com $40 \mathrm{mg} / \mathrm{dia}$ de isoflavona e $40 \mathrm{mg} / \mathrm{dia}$ de caseína, durante 24 semanas.

FIGURA 19 Representação gráfica das queixas clínicas das mulheres antes e após o tratamento com $40 \mathrm{mg} / \mathrm{dia}$ de isoflavona e $40 \mathrm{mg} / \mathrm{dia}$ de caseína, durante 24 semanas 


\section{LISTA DE TABELAS}

TABELA I Características das voluntárias.

TABELA II Tipos celulares do I.M. com dados extraídos do colpocitograma das mulheres antes e após o tratamento com $40 \mathrm{mg} / \mathrm{dia}$ de isoflavona e $40 \mathrm{mg} /$ dia de caseína, durante 24 semanas.

TABELA III Avaliação do I.P., I.E. e V.M. com dados extraídos do colpocitograma das mulheres antes e após o tratamento com 40 $\mathrm{mg} / \mathrm{dia}$ de isoflavona e $40 \mathrm{mg} / \mathrm{dia}$ de caseína, durante 24 semanas.

TABELA IV Tipos celulares do I.M. com dados extraídos do colpocitograma obtidos da secreção vaginal por exame direto a fresco (coleta úmida) das mulheres antes e após o tratamento com $40 \mathrm{mg} / \mathrm{dia}$ de isoflavona e $40 \mathrm{mg} /$ dia de caseína, durante 24 semanas.......

TABELA V Avaliação I.P., I.E. e V.M. com dados extraídos do colpocitograma obtidos da secreção vaginal por exame direto a fresco (coleta úmida) das mulheres antes e após o tratamento com $40 \mathrm{mg} / \mathrm{dia}$ de isoflavona e $40 \mathrm{mg} /$ dia de caseína, durante 24 semanas.

TABELA VI Tipos celulares do I.M. com dados extraídos do urocitograma das mulheres antes e após o tratamento com $40 \mathrm{mg} / \mathrm{dia}$ de isoflavona e $40 \mathrm{mg} /$ dia de caseína, durante 24 semanas.

TABELA VII Avaliação do I.P., I.E. e do V.M. com dados extraídos do urocitograma das mulheres antes e após o tratamento com 40 $\mathrm{mg} / \mathrm{dia}$ de isoflavona e $40 \mathrm{mg} / \mathrm{dia}$ de caseína, durante 24 semanas.

TABELA VIII Bacterioscopia da secreção vaginal das mulheres antes e após o tratamento com $40 \mathrm{mg} / \mathrm{dia}$ de isoflavona e $40 \mathrm{mg} / \mathrm{dia}$ de caseína, durante 24 semanas.

TABELA IX Soma dos Agentes Microbiológicos das mulheres antes e após o tratamento com $40 \mathrm{mg} / \mathrm{dia}$ de isoflavona e $40 \mathrm{mg} / \mathrm{dia}$ de caseína, durante 24 semanas.

TABELA X Índice de Nugent das mulheres antes e após o tratamento com $40 \mathrm{mg} / \mathrm{dia}$ de isoflavona e $40 \mathrm{mg} / \mathrm{dia}$ de caseína, durante 24 semanas. 
TABELA XI Colpocitologia das mulheres antes e após o tratamento com 40 $\mathrm{mg} / \mathrm{dia}$ de isoflavona e $40 \mathrm{mg} / \mathrm{dia}$ de caseína, durante 24 semanas

TABELA XII Soma das queixas clínicas antes e após o tratamento com isoflavona e uso de placebo (40mg/dia), no período de 24 semanas.

TABELA XIII Dez maiores queixas nas mulheres entrevistadas, antes do início do tratamento, nos grupos placebo e tratado com isoflavona

TABELA XIV Porcentagens de melhoras com isoflavona e placebo, quando comparada à soma das queixas antes e após o tratamento de 24 semanas

TABELA XV Determinação do índice de Kuppermann antes e após o tratamento com isoflavona e uso de placebo (40mg/dia), no período de 24 semanas.

TABELA XVI Metabólitos urinários antes e após 24 semanas de tratamento nos grupos placebo e tratado 


\section{ABREVIATURAS, SÍMBOLOS E SIMPLIFICAÇÕES}

AGUS - Atypical Glandular Cells of Undetermined Significance = Atipias Glandulares de significado indeterminado

AIS - Adenocarcinoma "in situ"

ASCUS - Atypical Cells of Undetermined Significance = Células do Epitélio Escamoso com Atipias de Significado Indeterminado

CAIS - Carcinoma "in situ"

DGGE - Denaturing Gradient Gel Eletrophoreses = electroforese em gel de gradiente desnaturante

DST - Doença Sexualmente Transmissível

EEC - Estrógeno Eqüino Conjugado

EGF - Epidermal Growth Factor = Fator de Crescimento Epitelial

ERE - Elemento de Resposta Estrogênica

FSH - Follicle-Stimulating Hormone = Hormônio Folículo Estimulante

g - - Gramas

GnRH - Gonadotropin-Releasing Hormone = Hormônio Liberador de Gonadotrofina

HDL - High-Density Lipoprotein = Lipoproteína de alta densidade

HIV - Human Immunodeficency vírus = Vírus da Imunodeficiência Humana

HPV - Human Papillomavirus = Papiloma vírus humano

HSIL - High Grade Squamous Intraepitelial Lesion = Lesão intraepitelial escamosa de alto grau

I.E. - Índice de Eosinofilia

I.M. - Índice de Maturação

IMC - Índice de Massa Corporal

I.P. - Índice de Picnose

JEC - Junção Escamo Colunar

$\mathrm{Kg} \quad$ - Kilogramas

LDL - Low-Density Lipoprotein = Lipoproteína de baixa densidade 
LH - Luteinizing Hormone = Hormônio Luteinizante

LSIL - Low Grade Squamous Intraepitelial Lesion = Lesão intraepitelial escamosa de baixo grau

$\mathrm{Mg} \quad$ - Miligramas

M - Metros

$\mathrm{M}^{2} \quad$ - Metros quadrados

$\mu \mathrm{g} \quad$ - Microgramas

$\mathrm{NCl} \quad$ - National Cancer Instituite = Instituto Naional do câncer

O-DMA - O-des-metil-angolesina

PCR - Polymerase Chain Reaction = Reação em cadeia da polimerase

SCC - Squamous Cell Carcinoma = Carcinoma de células escamosas

SHBG - Sex Hormone Binding Globulin = Globulina de ligação de hormônios sexuais

TAF - Transcriptional Activation Function = Função de ativação transcricional

TBS - The Bethesda System = Sistema Bethesda

TRH - Terapia de Reposição Hormonal

UI - Unidade Internacional

VLDL - Very Low Density Lipoprotein = Lipoproteína de densidade muito baixa

V.M. - Valor de Maturação 


\section{SUMÁRIO}

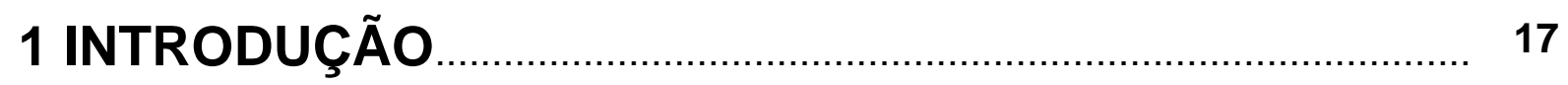

1.1 Fisiologia Hormonal ................................................................. 17

1.1.1 Ciclo menstrual ........................................................................... 18

1.1.2 Funções dos hormônios ovarianos................................................. 20

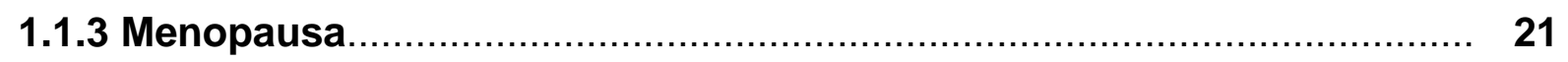

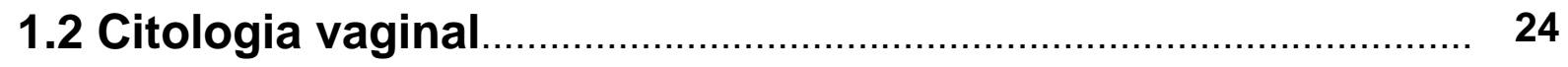

1.2.1 Microbiota Vaginal..................................................................... 25

1.2.2 Exame preventivo do câncer do colo uterino...................................... 28

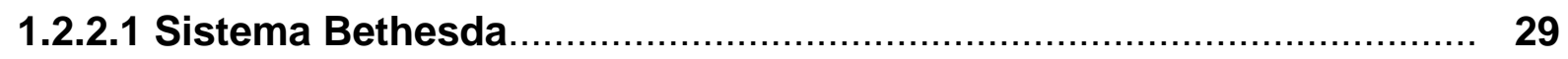

1.2.2.2 HPV e câncer cervical..................................................................... 30

1.2.3 Avaliação hormonal pela colpocitologia …………………………...... 33

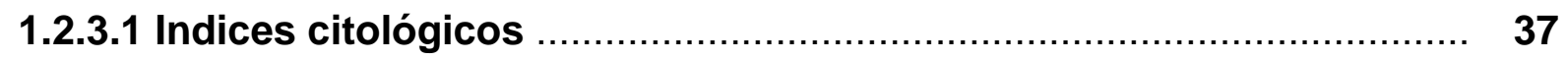

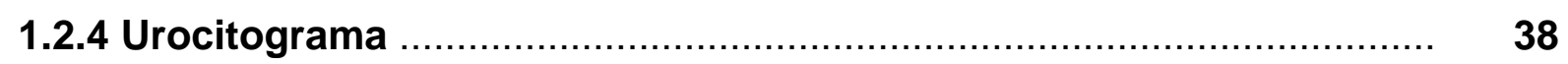

1.3 Avaliação dos sintomas da menopausa .................................... 39

1.4 Terapia de reposição hormonal...................................................... 41

1.4.1 Avaliação hormonal de terapia estroprogestiva pela colpocitologia.... 42

1.5 Fitoestrógenos .............................................................................. 46

1.5.1 Isoflavona e suas aplicações em menopausa..................................... 51

2 OBJETIVO

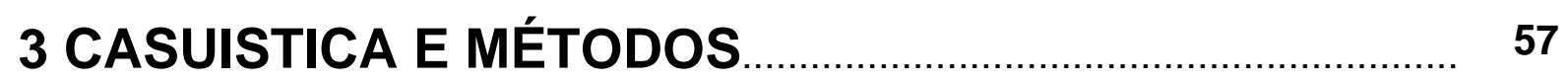

3.1 Protocolo clínico .......................................................................... 57

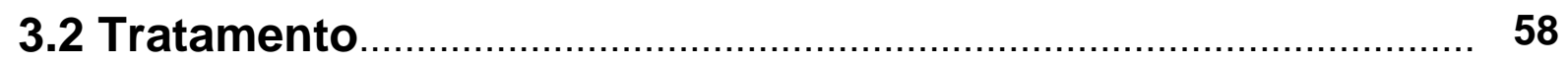

3.3 Exames constantes no prontuário médico................................. 58

3.4 Colheitas citológicas ................................................................... 59

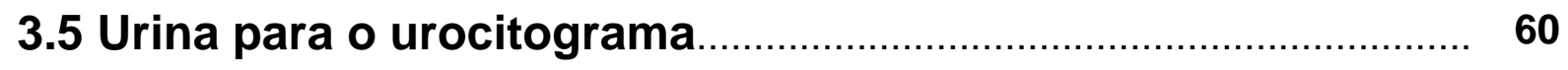

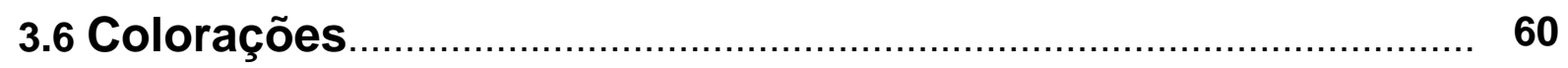

3.6.1 Coloração das lâminas para colpocitologia (shorr, modificado).

3.6.2 Coloração das lâminas da bacterioscopia (Gram 


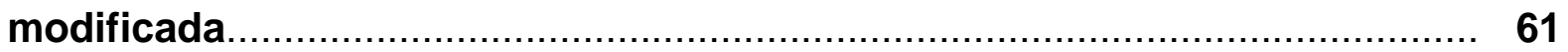

4 RESULTADOS

4.1 Maturação do epitélio vaginal .........................................................66

4.1.1 Colpocitograma - Índice de maturação............................................. 66

4.1.2 Colpocitograma - Índice de picnose, Índice de eosinofilia e valor de

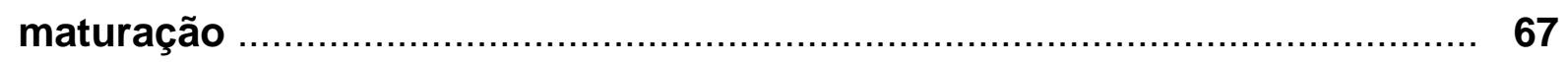

4.1.3 Colpocitograma (Coleta úmida) - Índice de maturação....................... 68

4.1.4 Colpocitograma - Coleta úmida - Índice de picnose, Índice de

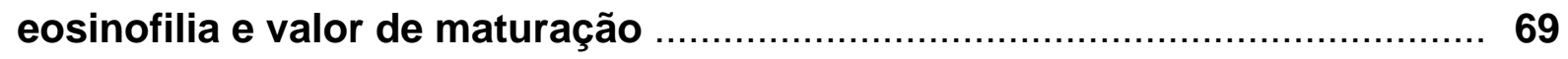

4.1.5 Urocitograma - Índice de maturação................................................ 70

4.1.6 Urocitograma - Índice de picnose, Índice de eosinofilia e valor de

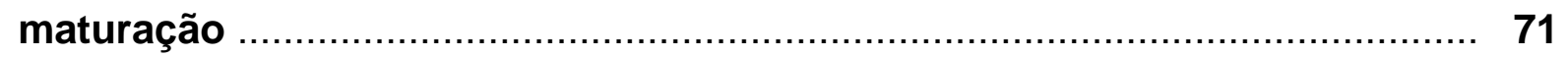

4.2 Microbiota Vaginal .................................................................. 72

4.3 Exames colpocitológicos ......................................................... 75

4.4 Sinais e sintomas da menopausa ............................................... 76

4.4.1 Queixas clínicas .................................................................... 76

4.4.2 Indice de Kuppermann ............................................................... 79

4.5 Metabólitos da Isoflavona .......................................................... 81

5 DISCUSSÃO

5.1 Maturação do epitélio vaginal...................................................... 84

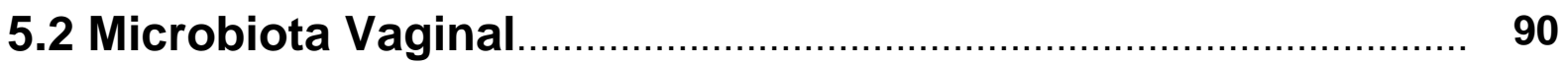

5.3 Exame Colpocitológico............................................................... 92

5.4 Sinais e sintomas da menopausa ............................................. 96

6 CONCLUSÃO

7 REFERÊNCIAS BIBLIOGRÁFICAS ..................................... 101

103 ANEXOS 


\section{INTRODUÇÃO}

A menopausa, causada pela falência ovariana, com conseqüente diminuição da produção hormonal, apresenta alterações que comprometem a qualidade de vida das mulheres na pós-menopausa. As modificações endocrinológicas promovidas pela menopausa exercem efeitos prejudiciais aos vasos sangüíneos aumentando a incidência de doenças cardiovasculares (BRITISH HEART FOUNDATION, 2000), perda óssea (ROSEN \& KESSINICH, 1997), diminuição da função cognitiva (SOLERTE et al., 1999), favorece o desenvolvimento da doença de Alzheimer (GIACOBINI, 1998), entre outros.

Com o objetivo de diminuir os sintomas indesejáveis associados à menopausa foram criadas as Terapias de Reposição Hormonal (TRH), usando hormônios exógenos. No entanto, o uso da TRH tem sido questionado por vários estudos, que evidenciam que TRH em mulheres com doenças cardiovasculares estabelecidas não são beneficiadas em relação a futuros eventos cardiovasculares (HULLEY et al., 1998; SIMON et al., 2006) nem progressão de lesões ateroscleróticas (HERRINGTON et al., 2000) e, além disso, existem polêmicas em relação à eficácia destes tratamentos como preventivos para doenças cardiovasculares (GENAZZANI et al., 2000; MOSCA et al., 2001). Outro problema relacionado ao uso da TRH apontado em grandes estudos é o aumento do risco do câncer de mama (EWERTZ et al., 2005; TAMIMI et al., 2006). Por estes motivos, são pesquisadas terapias alternativas e muitos grupos começaram a explorar a atividade de compostos naturais encontrados em certas plantas, em altas concentrações, conhecidos como fitoestrógenos.

\subsection{Fisiologia hormonal}

Durante a primeira década de vida, o sistema genital encontra-se em um estado juvenil. Em torno dos 10 anos de idade, iniciam-se as alterações reguladas pelos hormônios em ambos os sexos. A puberdade é o período em que as características sexuais secundárias começam a desenvolver-se e o potencial para a reprodução sexual é atingido. Nas mulheres, o ciclo reprodutivo normalmente ocorre uma vez por mês, a partir da primeira menstruação, chamada menarca, até a menopausa, que é a 
cessação permanente das menstruações. Desse modo, o sistema genital feminino tem um tempo limitado de fertilidade, entre a menarca e a menopausa, período este denominado menacme ou fase reprodutiva da mulher (TORTORA \& GRABOWSKI, 2006).

\subsubsection{Ciclo menstrual}

Os anos reprodutivos normais na mulher são caracterizados por alterações rítmicas mensais das taxas de secreção dos hormônios femininos e alterações correspondentes nos ovários e órgãos sexuais. Este padrão rítmico é chamado ciclo sexual feminino. O ovário consiste de folículos esféricos embebidos em um estroma, que por sua vez, é circundado por uma membrana contendo um gameta (oócito, ovo, óvulo). Inicialmente, existem aproximadamente 7 milhões de ovos, dos quais uma grande proporção morre antes do nascimento e durante a infância, sendo na puberdade diminuído para aproximadamente 400.000 óvulos (GUYTON \& HALL, 2002; PAGE et al., 2004; TORTORA \& GRABOWSKI, 2006).

Cada ciclo leva cerca de um mês e envolve a ovogênese e a preparação do útero para receber um óvulo fertilizado. Esses eventos são controlados pela secreção rítmica dos hormônios estrógenos e progesterona, que são produzidos pelos ovários e causa alterações nos órgãos efetores do sistema reprodutivo (vagina, muco cervical, endométrio e centro térmico hipotalâmico) (TORTORA \& GRABOWSKI, 2006).

O sistema hormonal feminino, tal como o masculino, é constituído por três hierarquias de hormônios. O hormônio liberador de gonadotrofinas $(\mathrm{GnRH})$, anteriormente chamado também de hormônio de liberação do hormônio luteinizante, é liberado pelo hipotálamo e estimula a hipófise anterior, que por sua vez, libera o hormônio folículo estimulante $(\mathrm{FSH})$ e o hormônio luteinizante $(\mathrm{LH})$, ambos secretados em resposta ao hormônio de liberação GnRH. O FSH e o LH atuam nos ovários, que liberam os hormônios estrogênio e progesterona, respectivamente (FIGURA 1) (GUYTON \& HALL, 2002). 


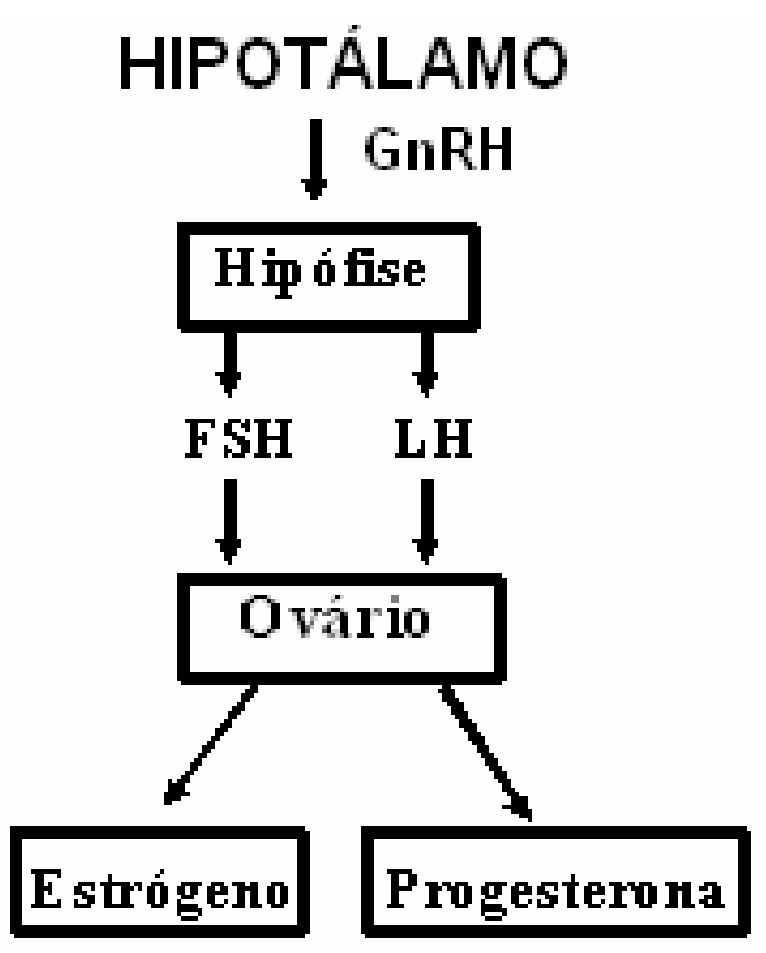

FIGURA 1 - Representação esquemática do controle hormonal do sistema reprodutivo feminino.

Didaticamente, e de acordo com as flutuações hormonais, o ciclo menstrual é dividido em fases. Uma divisão simplificada, adotada por Frankovich \& Lebrun (2000), considera duas fases: a folicular, compreendendo o período do sangramento até a ovulação (inclusive), e a lútea, que se inicia logo após, estendendo até o início de um novo sangramento. Em relação aos níveis hormonais, a fase folicular caracteriza-se pela presença do FSH e estrógeno, os quais levam ao crescimento do folículo ovariano e pela ação do LH promovendo liberação do óvulo maduro e consequentemente, à ovulação. A fase lútea é caracterizada pela presença aumentada de progesterona e a presença em menor proporção de hormônio estrogênico. O decréscimo destes dois hormônios ocorre com a regressão do corpo lúteo (quando não ocorreu fertilização), gerando a degeneração do endométrio que fisiologicamente representa a menstruação ou sangramento mensal (FIGURA 2) (SAMPAIO, 2002). 


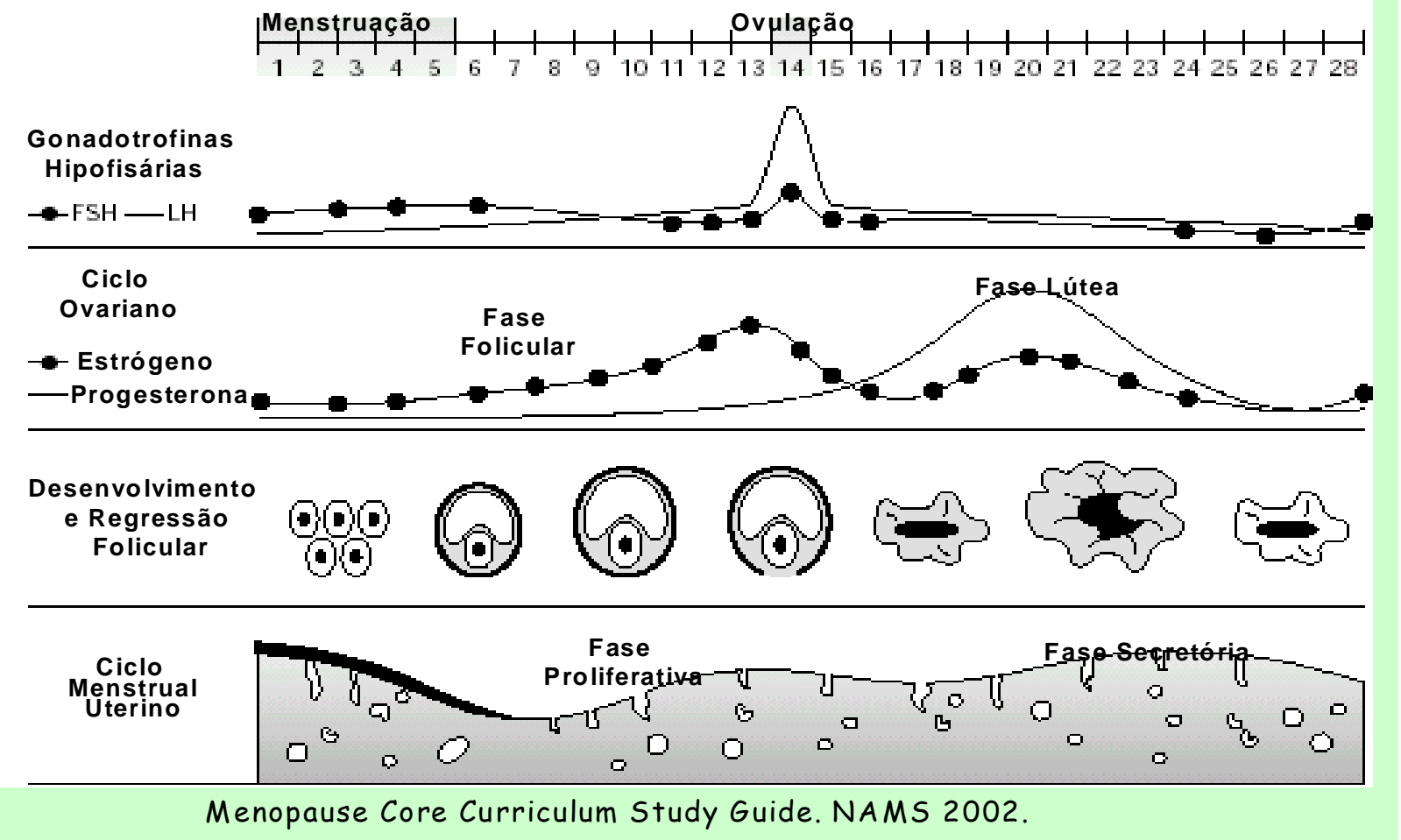

FIGURA 2 - Representação esquemática do controle hormonal do ciclo menstrual.

\subsubsection{Funções dos hormônios ovarianos}

Os dois tipos de hormônios sexuais ovarianos estrogênio e a progesterona, na mulher normal não-grávida, são secretados em quantidades maiores apenas pelos ovários, apesar de quantidades diminutas de estrógeno também serem secretadas pelo córtex da adrenal. $\mathrm{Na}$ gravidez, grandes quantidades de progesterona também são secretadas pela placenta. Apenas três estrogênios estão presentes em quantidades significativas no plasma feminino humano: $\beta$-estradiol, estrona e estriol, sendo o principal secretado pelo ovário o $\beta$-estradiol (FIGURA 3A). A função principal dos estrogênios é causar a proliferação celular e o crescimento dos tecidos dos órgãos sexuais e de outros tecidos relacionados com a reprodução (GUYTON \& HALL, 2002).

Por outro lado, a mais importante das progestinas é a progesterona (FIGURA 3B). No entanto, pequenas quantidades de outra progestina, a 17- $\alpha$-hidroxiprogesterona, também são secretadas juntamente com a progesterona pelos ovários e têm essencialmente os mesmos efeitos desta última. Na mulher normal não-grávida, a 
progesterona é secretada em quantidades significativas apenas durante a segunda metade de cada ciclo ovariano, quando é secretado pelo corpo lúteo, sendo sua principal função promover alterações secretoras no endométrio uterino durante a segunda metade do ciclo sexual, preparando assim o útero para a implantação do ovo fertilizado (GUYTON \& HALL, 2002).

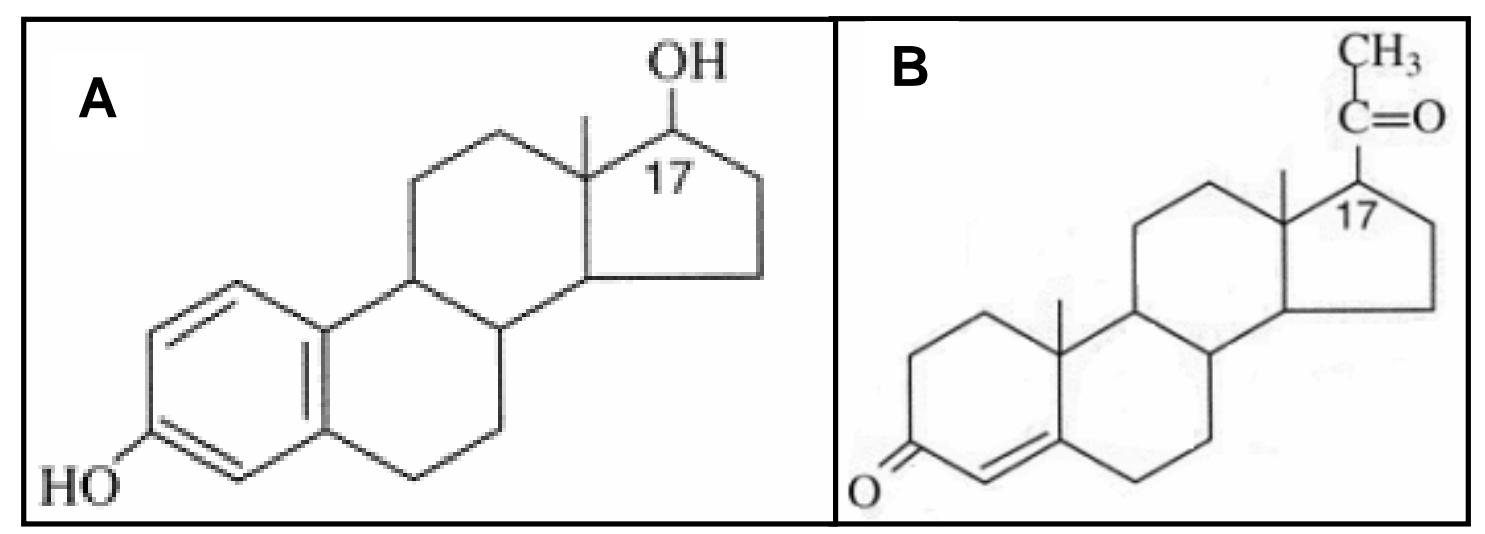

FIGURA 3 - Estrutura dos principais hormônios ovarianos - 17ß-estradiol (A) e progesterona $(\mathrm{B})$.

\subsubsection{Menopausa}

O climatério representa a transição entre a fase reprodutiva e a não reprodutiva, ou seja, da menacme até a interrupção dos ciclos menstruais, com conseqüências sistêmicas e potencialmente patológicas. É um fenômeno fisiológico decorrente do esgotamento dos folículos ovarianos, que ocorre em todas as mulheres de meia idade, seguido da diminuição progressiva da secreção de estrogênio, culminando com a interrupção definitiva da menstruação, denominada menopausa e o surgimento dos sintomas característicos (BOSSEMEYER, 1999).

Os principais sinais e sintomas associados a este período são vasomotores, no qual ocorrem ondas de calor, sudorese, insônia, palpitações; psicológicos, com mudanças de humor, ansiedade, depressão, perda de memória, da concentração e irritabilidade; urogenitais, o que leva a ressecamento da vagina, perda da libido, dispareunia, incontinência urinária e disúria (BARNABEl et al., 2002). 
Várias alterações que ocorrem na menopausa são decorrentes da diminuição da produção de estrógeno, ou hipoestrogenismo fisiológico, sendo as principais as vasomotoras e urogenitais. Por outro lado, os sintomas de natureza somática como a irritabilidade, a maior labilidade emocional, alterações da libido, perda cognitiva, distúrbios do sono, dores articulares/mialgias estão fortemente associados a fatores psico-sociais, estilo de vida e, principalmente, com a percepção da mulher do que representa a menopausa para a sua vida (OLOFSSON \& COLLINS, 2000).

A sintomatologia climatérica não é igual em todas as mulheres. A maior prevalência de irritabilidade, melancolia ou tristeza entre as mulheres merece atenção e é fundamental a diferenciação da verdadeira natureza dos sintomas relatados durante o climatério, em especial os relacionados à depressão. A maior prevalência de estados depressivos no climatério estaria associada ao medo de envelhecer, sentimentos de inutilidade e até carência afetiva, uma vez que esta fase da vida coincide com o crescimento e independência dos filhos, viuvez e aposentadoria, eventos que são difíceis para a mulher. Isto pode ser comprovado, quando se observa que as mulheres com uma relação estável, realizadas profissionalmente e com atitudes positivas em relação ao envelhecimento tendem a apresentar menos sintomas depressivos. Outra queixa comum, a insônia pode estar relacionada à ocorrência de sintomas vasomotores e a estados de maior irritabilidade (AVIS et al., 2001).

A aproximação da menopausa causa muitas dúvidas nas mulheres, o que pode gerar ansiedade e apreensão. Corroborando com isto, um estudo demonstrou que as mulheres de meia idade submetidas a intervenções educativas expressam menos crenças negativas sobre a menopausa, com conseqüente redução dos níveis de ansiedade e menor sintomatologia climatérica. Mais da metade das entrevistadas confirmou atividade sexual no último ano em relação ao estudo, sendo que inicialmente a maior freqüência da atividade sexual associou-se a menor sintomatologia climatérica. As dificuldades na esfera sexual seriam menores entre as mulheres que vivenciam positivamente o climatério, percebendo nesta fase redução das obrigações profissionais e com os filhos, uma oportunidade para um maior exercício afetivo-sexual. Entre as mulheres que associam a menopausa à velhice, a sexualidade foi gravemente comprometida. Clinicamente, o hipoestrogenismo 
climatérico é responsável pela atrofia urogenital, o que favorece a ocorrência de dispareunia. Paralelamente, o envelhecimento cutâneo por redução do colágeno e a tendência de acúmulo de gordura afetam a auto-imagem, contribuindo para menor auto-estima e até declínio do desejo sexual. Os próprios sintomas vasomotores podem interferir na atividade sexual da mulher. O medo de uma gestação indesejada, o constrangimento pelo desejo sexual e eventuais dificuldades no relacionamento com o parceiro são fatores que igualmente podem interferir na satisfação sexual feminina no climatério (de LORENZI et al., 2005).

Além da questão educativa, o estilo de vida também interfere nos sintomas relatados durante a menopausa. Estudos indicam que as mulheres climatéricas que praticam regularmente exercícios físicos tendem a ter melhor humor, menor perda de memória e menos sintomas somáticos. O exercício físico estimula a secreção de endorfinas hipotalâmicas, substâncias estas envolvidas na termorregulação hipotalâmica, reduzindo os sintomas vasomotores; promove o fortalecimento muscular, a manutenção da mobilidade articular e da capacidade respiratória, além de menor acúmulo de gordura. A atividade física contribui ainda para a melhora da imagem corporal, aumentando a auto-estima feminina. O exercício físico regular tem sido recomendado na prevenção e tratamento dos processos de osteoartrite, comuns no processo de envelhecimento, podendo ser causa de artralgias, mialgias e até limitações dos movimentos que são queixas com elevada prevalência nesta fase da vida. Nas sociedades orientais, nas quais a menopausa é fator de valorização feminina, uma vez que o envelhecimento está associado à sabedoria e experiência, os sintomas climatéricos tendem a ser menos intensos ou mesmo ausentes. No entanto, nas culturas ocidentais, em que a juventude feminina e a beleza são excessivamente valorizadas, a menopausa é freqüentemente percebida de forma negativa, sendo associada ao envelhecimento e a maior proximidade da morte, a sintomatologia climatérica é freqüentemente mais intensa (THOMPSON et al., 2003; McMILLAN \& MARCK, 2004).

Considerando o sobrepeso e obesidade, tomando como referência o grupo com peso adequado, as mulheres na faixa etária de 50 a 59 anos têm três vezes maior chance de estar com sobrepeso e sete vezes maior chance de serem obesas que as mulheres com idade até 29 anos. Na visão dos profissionais de saúde que trabalham 
com mulheres, estes resultados tornam-se importantes, já que são as faixas de idade que coincidem com o climatério e pós-menopausa, períodos em que as mulheres passam a ter maior risco para doença cardiovascular (FERNANDES et at., 2005).

\subsection{Citologia Vaginal}

A citologia vaginal é avaliada laboratorialmente através do exame colpocitológico ou também esfregaço de Papanicolaou, como é conhecido ainda nos dias de hoje (PAPANICOLAU \& TRANT, 1941). A colpocitologia ou citologia tríplice consiste na colheita de células descamadas da superfície externa do colo uterino também chamado ectocérvice, internamente ao canal uterino, o endocérvice, e da parede vaginal, no seu terço posterior. Considerando a cavidade vaginal e o colo uterino (ecto e endocérvice) pode-se distinguir três mucosas: 1) mucosa escamosa; 2) mucosa glandular. 3) mucosa de transformação. Não há limite nítido entre a mucosa que reveste a vagina e a mucosa escamosa do ectocérvice. A mucosa escamosa das mulheres em fase reprodutiva é formada pelo epitélio escamoso pluriestratificado não ceratinizado e pela lâmina própria, de natureza conjuntiva. As camadas do epitélio da profundidade para a superfície são: camada germinativa ou basal, camada parabasal, camada intermediária e camada superficial (FIGURA 4).

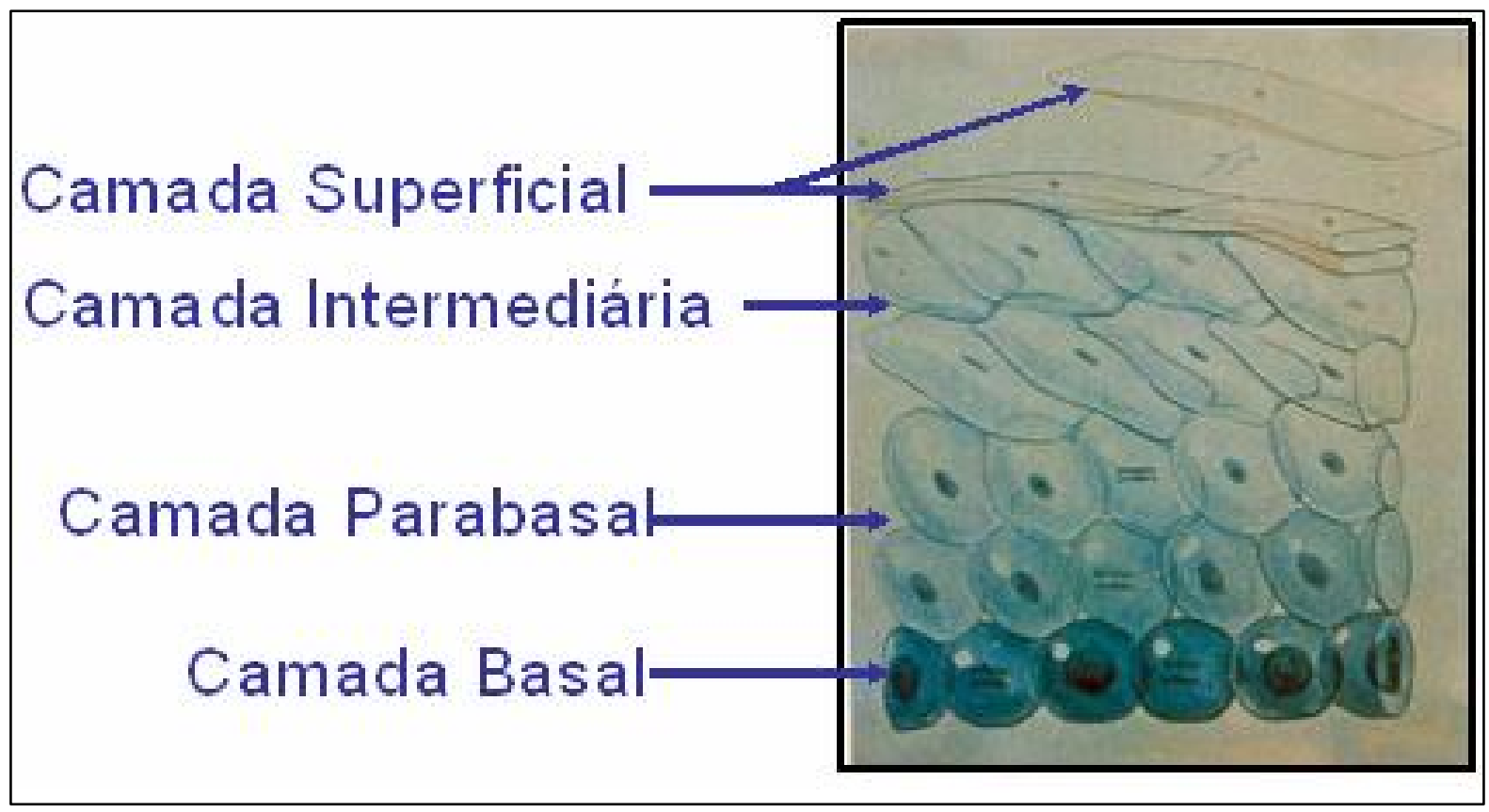

FIGURA 4 - Respresentação esquemática do epitélio pluriestratificado pavimentoso não ceratinizado da vagina e ectocérvice, na mulher em idade reprodutiva. 
O epitélio escamoso vaginal varia consideravelmente em espessura dependendo da idade da mulher. Sendo fino, nas meninas pré-púberes e nas mulheres pósmenopausadas. A mucosa glandular é representada pelo epitélio cilíndrico mucíparo que reveste o canal endocervical. Este epitélio secreta um muco que é deslocado na direção do orifício do colo uterino, visando eliminar impurezas e restos celulares (McKEE, 1997).

A mucosa de transformação, também chamada terceira mucosa faz a junção entre os epitélios escamoso e cilíndrico glandular e recebe o nome de junção escamo colunar (JEC). Anatomicamente, esta região é extremamente importante por ser o ponto vulnerável nos processos inflamatórios e por ser também uma região de grande impacto durante o coito, nas mulheres com vida sexual ativa. Desta forma, o exame colpocitológico composto por células descamadas dos compartimentos vaginais, ecto e endocervical tem como aplicações clínicas a pesquisa de patógenos que podem acometer a cavidade vaginal; o diagnóstico preventivo do câncer de colo uterino através da análise morfológica das células da JEC e dos dois epitélios envolvidos (colunar e escamoso) e avaliação hormonal da paciente através de análise da maturação celular das células vaginais (AYALLA et al., 1985).

\subsubsection{Microbiota vaginal}

A microbiota vaginal normal da mulher na fase reprodutiva é constituída predominantemente por lactobacillus L.iners, L.acidophillus, L. fermentum, $L$. plantarum, L. brevis, L. jensenii, L. casei, L. delbrueckii, L. vaginalis, L. salivarius também conhecidos como bacilos de Döederlein (ANUKAM et al., 2006).

A coloração de Gram é um método barato que facilita a identificação de morfotipos bacterianos, como o Lactobacilos sp, Gardnerella vaginalis, Bacteróides, cocos Gram positivos, bacilos Gram negativos ou Gram variáveis curvos, Mobyluncus $s p$, podendo ampliar o estudo da microbiota vaginal. Contando-se os morfotipos bacterianos em imersão obtem-se índice de Nugent ( 0 a 3 vagina normal, 4 a 6 colonização intermediária e 7 a 10 vaginose bacteriana), podendo inclusive 
acompanhar a evolução do tratamento da paciente portadora de vaginose bacteriana (FIGURA 5) (NUGENT et al., 1991).

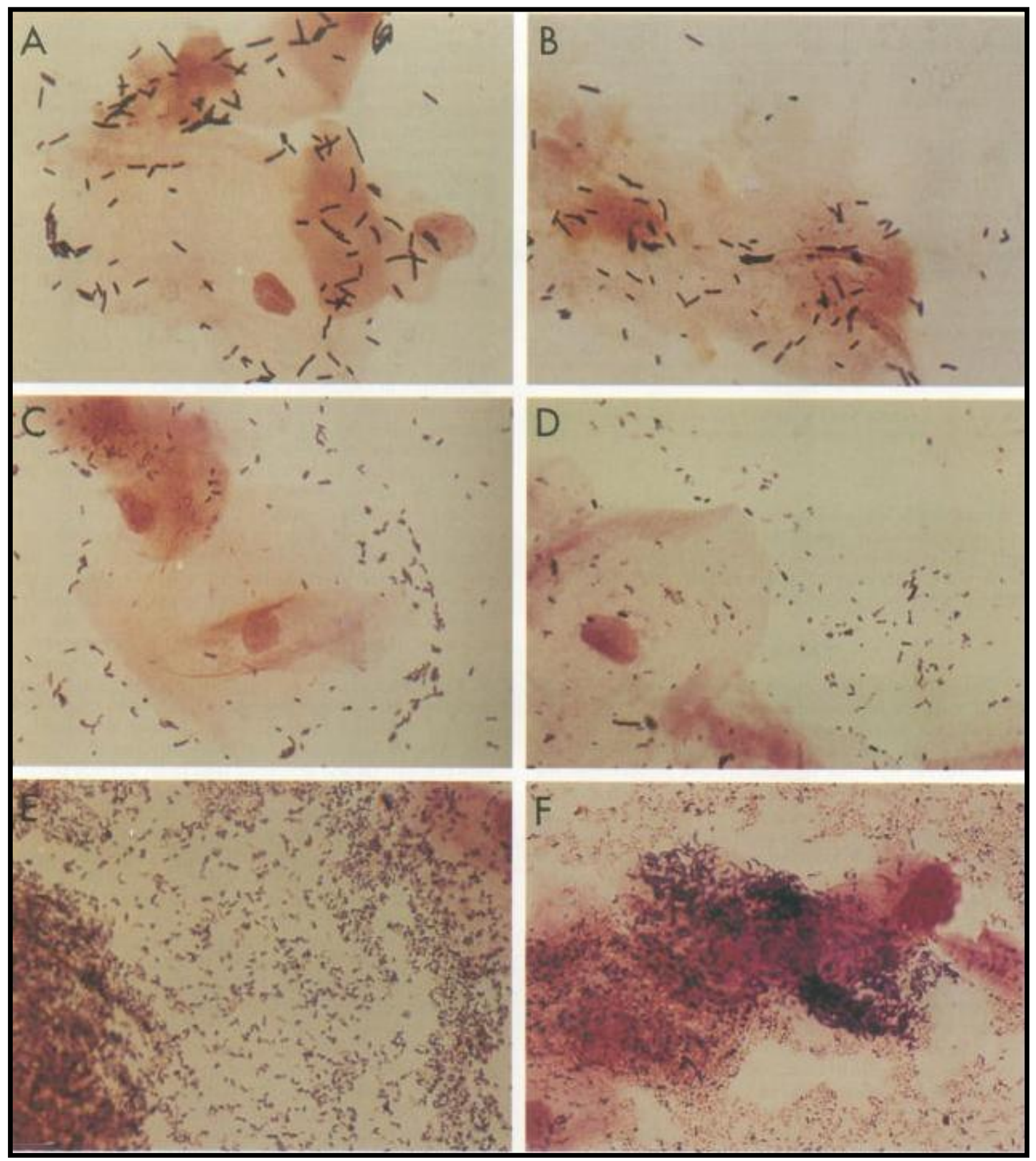

FIGURA 5 - Microbiota Vaginal bacteriana, em esfregaços corados pelo método de Gram: A e B flora vaginal normal, C e D flora vaginal intermediária e E e F, vaginose bacteriana (NUGENT et al., 1991). 
A técnica do exame direto a fresco ajuda a determinar os morfotipos dos bacilos de Döederlein, das formas das outras bactérias presentes, com melhor eficiência que a técnica de Gram. Isto se torna relevante quando há algum interesse na contagem das bactérias, pois a fixação e a coloração como é necessário no exame colpocitológico facilitam sua degeneração. Também as células no exame a fresco estão melhores conservadas que na coleta tríplice, coradas pelas técnicas de Gram, Papanicolaou ou Shorr (DONDERS et al., 2000).

Durante um estudo para monitorar a microflora vaginal bacteriana em 20 mulheres na menopausa, usando índice de Nugent (esfregaços vaginais, corados pela técnica de Gram), com confirmação pelas técnicas da reação da polimerase em cadeia $(P C R=$ polymerase chain reaction $)$ e em eletroforese em gel de gradiente desnaturante (DGGE = denaturing gradient gel electrophoresis), foram detectadas bactérias responsáveis pela vaginose bacteriana em $70 \%$ das mulheres monitoradas (BURTON \& REID, 2002).

Dentre os organismos associados a modificações inflamatórias mais freqüentes do esfregaço vaginal podem ser citadas Cândida sp, Torulopsis glabrata, Actnomicetos dentre os fungos, Trichomonas vaginalis, Amebas dentre os protozoários; cocos Chlamydia trachomatis e Gardnerella vaginalis, cocobacilos; Bacilos de Döederlein, outros bacilos dentre as bactérias; Herpes simplex, Papilomavírus humano (HPVHuman Papillomavirus) como os vírus mais comumente encontrados; ovos de parasitos intestinais, ácaros e piolho (TAKAHASHI, 2000; McKEE, 1997).

As mulheres com história ou portadoras de Doenças Sexualmente Transmissíveis (DST) apresentam prevalência cinco vezes maior de lesões precursoras do câncer cérvico-vaginal. A tricomoníase vaginal e outras DST's podem permanecer assintomáticas na mulher, principalmente na menopausa, assim como nos homens. As DST's são os principais fatores facilitadores da transmissão sexual do vírus da imunodeficiência humana (HIV - Human Immunodeficiency Vírus) (MANUAL DE CONTROLE DAS DST-MS-1999).

A presença de estrogênio influencia a composição da microflora vaginal por estimular a deposição de glicogênio no epitélio vaginal. O glicogênio se transforma em glicose 
e, em seguida, se converte em ácido lático pelo metabolismo celular na mulher em idade reprodutiva. Na menopausa a redução do estrogênio e, conseqüentemente, da deposição de glicogênio no epitélio vaginal causa alteração da flora e do pH vaginal, favorecendo a invasão da cavidade vaginal por patógenos (HILLIER \& LAU, 1997).

\subsubsection{Exame Preventivo do Câncer do Colo Uterino}

O colo do útero é revestido, de forma ordenada, por várias camadas de células epiteliais, pavimentosas que, ao sofrerem transformações, podem evoluir para uma lesão cancerosa do colo uterino, que é uma doença cuja evolução é lenta, apresentando fases pré-invasivas e, portanto, benignas. O período de evolução de uma lesão cervical inicial para a forma invasiva e, por conseguinte, maligna é de aproximadamente 20 anos. Este período relativamente longo permite que ações preventivas sejam eficientes e alterem o quadro epidemiológico da doença. Estas ações se fazem por meio da educação popular, detecção e diagnósticos precoces, tratamento das lesões cervicais precursoras. Agindo precocemente, pode-se alterar a história natural da doença, proporcionando a diminuição de sua morbidade e mortalidade. $\mathrm{O}$ rastreamento ou screening permite o diagnóstico precoce do câncer de colo uterino, das lesões de colo em suas fases iniciais antes de se tornarem lesões invasivas através de um método de detecção conhecido como colpocitologia oncótica ou exame de Papanicolaou (MANUAL TECNICO DE PREVENÇÃO DO CÂNCER DO COLO DO ÚTERO-MS, 2002).

É muito importante implementar os programas de prevenção do câncer de colo do útero, aliando a citologia oncótica a técnicas convencionais e modernas, como exames de biologia molecular, para o acompanhamento das pacientes com lesões suspeitas de malignidade ou malignas. Estima-se que $40 \%$ das mulheres brasileiras nunca tiveram acesso ao exame citopatológico (MANUAL TÉCNICO DE PREVENÇÃO DO CÂNCER DO COLO DO ÚTERO - MS - 2002).

As mulheres mais jovens têm um número maior de lesões epiteliais de baixo grau (LSIL), ao passo que as mulheres dos 50 aos 60 anos têm maior proporção de câncer invasivo, provavelmente relacionado com a imunidade deste período (LAWSON et al., 1998). Existe orientação para um espaçamento maior entre as 
coletas e até interrupção da citologia cérvico-vaginal após os 60 anos, porém em uma revisão de doze estudos realizados entre 1995 e 2001 demonstrou que uma, ou até duas mulheres em 1000, com história de exames colpocitológicos normais evoluíram de lesões de alto grau para câncer endocervical. Em mulheres que realizaram o primeiro exame colpocitológico entre os 50 e 64 anos encontrou-se casos de câncer em 2,3 de 1000 e, em mulheres cuja primeira coleta foi feita acima dos 65 anos, ocorreu 1,7 casos de câncer num total de 1000 (CURRAN \& STIGLEMAN, 2004).

\subsubsection{Sistema Bethesda}

Em dezembro de 1988, o $\mathrm{NCl}$ (National Cancer Institute), com o objetivo de padronizar os relatórios de resultados de citologia cérvico-vaginal, promoveu um encontro de especialistas na cidade de Bethesda, Estados Unidos. As normas propostas neste evento e nos encontros posteriores são conhecidas como Sistema Bethesda, (TBS-The Bethesda System). O Sistema Bethesda é a forma mais moderna de se relatar laudos colpocitológicos e é usado nas pesquisas, pois usa uma nomenclatura mundialmente conhecida (THE BETHESDA SYSTEM, 1993).

Os resultados da citologia oncótica são categorizados em três tipos:

1) Esfregaços dentro dos limites da normalidade.

2) Esfregaços com alterações benignas, quer incluam modificações reativas e infecções.

3) Esfregaços com anormalidades celulares:

\section{No epitélio escamoso}

- $\quad$ Atypical Cells of Undetermined Significance (ASCUS) - células do epitélio escamoso com atipias de significado indeterminado.

- Low Grade Squamous Intraepitelial Lesion (LSIL) - lesão de baixo grau do epitélio escamoso (inclui infecção pelo HPV), sem grandes alterações celulares.

- $\quad$ High Grade Squamous Intraepitelial Lesion (HSIL) - Lesão de alto grau do epitélio escamoso. 
- Squamous Cell Carcinoma (SCC) - Carcinoma de células do epitélio escamoso. Quando o carcinoma não é invasivo, pode ser classificado com Carcinoma "in situ" (CAIS).

\section{No epitélio glandular}

A presença de células endometriais, mesmo normais, em mulheres na menopausa, sem reposição hormonal, merece melhor investigação.

- Atypical Glandular Cells of Undetermined Significance (AGUS) - atipias glandulares de significado indeterminado.

- Adenocarcinoma - Indica um tumor, provavelmente invasivo. 0 adenomacarcinoma não invasivo é o Adenocarcinoma "in situ" (AIS). (THE BETHESDA SYSTEM, 1993).

Uma amostra satisfatória para avaliação deve ter identificação da paciente, informações clínicas relevantes, número adequado de células epiteliais escamosas bem preservadas, e em pacientes com a cérvix íntegra, um número de células endocervicais (zona de transformação). Com relação às células endocervicais devese ter pelo menos 2 aglomerados destas células bem conservadas e/ou células escamosas metaplásicas com pelo menos 5 células; este critério, segundo Bethesda, deve ser válido tanto para mulheres em pré como em pós-menopausa, exceto em situações de extrema atrofia onde não se pode distinguir as células endocervicais das parabasais.

A qualidade dos esfregaços pode estar limitada por grande quantidade de hemácias, de leucócitos, áreas espessas, fixação inadequada, dessecamento ou qualquer contaminante que impeça a interpretação de 50 a $75 \%$ do esfregaço. Se ocorrer limitação que comprometa mais que $75 \%$ da interpretação do esfregaço, a amostra será considerada insatisfatória. Lâminas quebradas que não possam ser reparadas adequadamente são consideradas insatisfatórias.

\subsubsection{HPV e Câncer Cervical}

Existem evidências de que a presença e persistência de infecção pelo HPV oncogênico são as principais causas do câncer cervical e estão envolvidas em outros 
tipos de câncer (ânus, vulva, vagina, orofaringe) (ZUR HAUSEN, 2000; NCl, 2001). A infecção pelo HPV oncogênico eleva a possibilidade de infecção persistente, da integração viral e representa um prognóstico de progressão neoplásica mais significante que a carga viral de HPV. As mulheres com maior carga viral, associado principalmente a vírus oncogênicos, o risco de neoplasia é maior (BURK, 1999).

Os HPVs são classificados de acordo com seu potencial de malignidade em grupos de baixo e alto risco. Ambos os tipos podem levar a um crescimento celular anormal, mas geralmente, apenas aqueles classificados como sendo de alto risco levam ao surgimento de carcinoma. Os tipos virais classificados no grupo de baixo risco (tipos $6,11,26,42,43,44,54,70$ e 73) são normalmente associados a lesões benignas exofíticas como condiloma acuminado, verrugas genitais comuns, condilomas planos, ou seja, lesões de baixo grau. Os tipos virais mais frequentemente encontrados em carcinomas cervicais de células escamosas, classificados de alto risco são tipos 16, $18,31,33,35,39,45,50,51,52,53,56,58,59,64,68$ e 69 (MILDE-LANGOSCH et al., 2000).

Visando melhorar o diagnóstico para HPV envolvido na etiologia do câncer cervical, pela citologia cérvico-vaginal e biologia molecular, por captura híbrida, foi gerado um consenso no Canadá, adaptando tecnologia, educação e novos focos de pesquisa (STUART et al., 2004). Deste consenso foi estabelecido que pacientes com alterações citopáticas compatíveis com HPV devem ser submetidas a testes confirmatórios de biologia molecular para determinar os sorotipos e carga viral visando prevenção e tratamento de lesões malignas e pré-malignas. A citologia tríplice, nestes casos é de baixa resolução, dando-se preferência aos exames de biologia molecular (HPV - MS, 2003).

A inspeção visual do colo uterino pode ser feita de diferentes modos: a) com ácido acético a sensibilidade se torna diretamente proporcional ao tamanho e gravidade das lesões e inversamente proporcional às alterações epiteliais decorrentes do envelhecimento fisiológico da mulher, as quais tornam a interpretação dos testes de inspeção visual bem mais difícil, b) pela captação do iodo, denominado teste de Schiller, torna-se menos intenso com o avançar da idade, em virtude da menor espessura do epitélio da ectocérvice (que fica restrito às suas camadas mais 
profundas), devido à diminuição da zona de transformação e à localização endocervical da JEC. Examinando 1997 mulheres na China encontrou-se aumento de especificidade e sensibilidade quando combinaram colposcopia para dirigir biopsias após inspeção visual com acido acético e iodo, exame colpocitológico de camada delgada e método molecular pela captura híbrida, para mulheres com resultado de ASCUS e displasia de moderada a grave (BELISON et al., 2002).

O êxito no rastreamento do câncer de colo uterino e das lesões precursoras dependerá, além de outros fatores, da acuidade diagnóstica do exame colpocitológico, ou seja, da sua precisão em diagnosticar corretamente os casos verdadeiros de lesões cervicais neoplásicas e pré-neoplásicas (sensibilidade) e aqueles casos que não apresentam qualquer tipo de alteração epitelial (especificidade). O exame de Papanicolaou é considerado um método altamente confiável para detectar as lesões cervicais e a sensibilidade deste teste, ou seja, a proporção de casos verdadeiros positivos detectados já foi descrita como sendo próxima de 99,8\%. Além de sua acuidade diagnóstica, o exame de Papanicolaou é considerado um método de baixo custo, simples e de fácil execução. Estas características o tornam amplamente usado em programas de controle do câncer cérvico uterino (PINHO \& MATTOS, 2002).

A colpocitologia oncótica, embora seja o exame de rastreamento do câncer cervical mais difundido e aceito em todo o mundo, apresenta imperfeições evidentes. Uma de suas maiores limitações é a elevada taxa de resultados falso-negativos, com todas as implicações médicas, financeiras e legais dela decorrentes. A maioria de suas falhas resulta de erros na obtenção do esfregaço e apenas um terço, de erros na leitura das lâminas. Cordeiro et al. (2005) encontraram um grande número de mulheres com cervicite em atividade em sua amostragem populacional, de 893 mulheres, provavelmente relacionado com o elevado número de exames de colpocitologia falsamente negativos encontrados. Neste estudo a maioria dos resultados anormais da colpocitologia e do estudo histopatológico foi de infecções pelo vírus HPV e lesão de baixo grau. Esta pode ter sido uma das razões da baixa sensibilidade estimada para colpocitologia que, não obstante, situou-se ainda dentro da faixa de 11 a $99 \%$. 


\subsubsection{Avaliação hormonal pela colpocitologia}

Durante os anos de reprodução o epitélio pluriestratificado pavimentoso não ceratinizado é espesso, mas tal espessura pode variar se a paciente estiver utilizando algum tipo de contracepção hormonal, visto ser um epitélio hormôniodependente. O epitélio escamoso é constituído por células lábeis, que se multiplicam, amadurecem e descamam. Por outro lado, as células da camada basal não se descamam, apenas se dividem e as células intermediárias e as superficiais são células maduras que não apresentam atividade reprodutiva. $\mathrm{O}$ amadurecimento do epitélio escamoso é conduzido pela ação dos hormônios esteróides. O estrógeno é o hormônio que produz o amadurecimento total deste epitélio, descamando a camada superficial. A progesterona produz amadurecimento parcial deste epitélio, até a camada intermediária. A testosterona promove o amadurecimento das células das camadas basais, sem atingir a camada de células intermediárias. A Figura 6 representa os tipos celulares que constituem o epitélio pluriestratificado pavimentoso não ceratinizado da mulher em menacme (WIED \& BIBBO, 1991). 


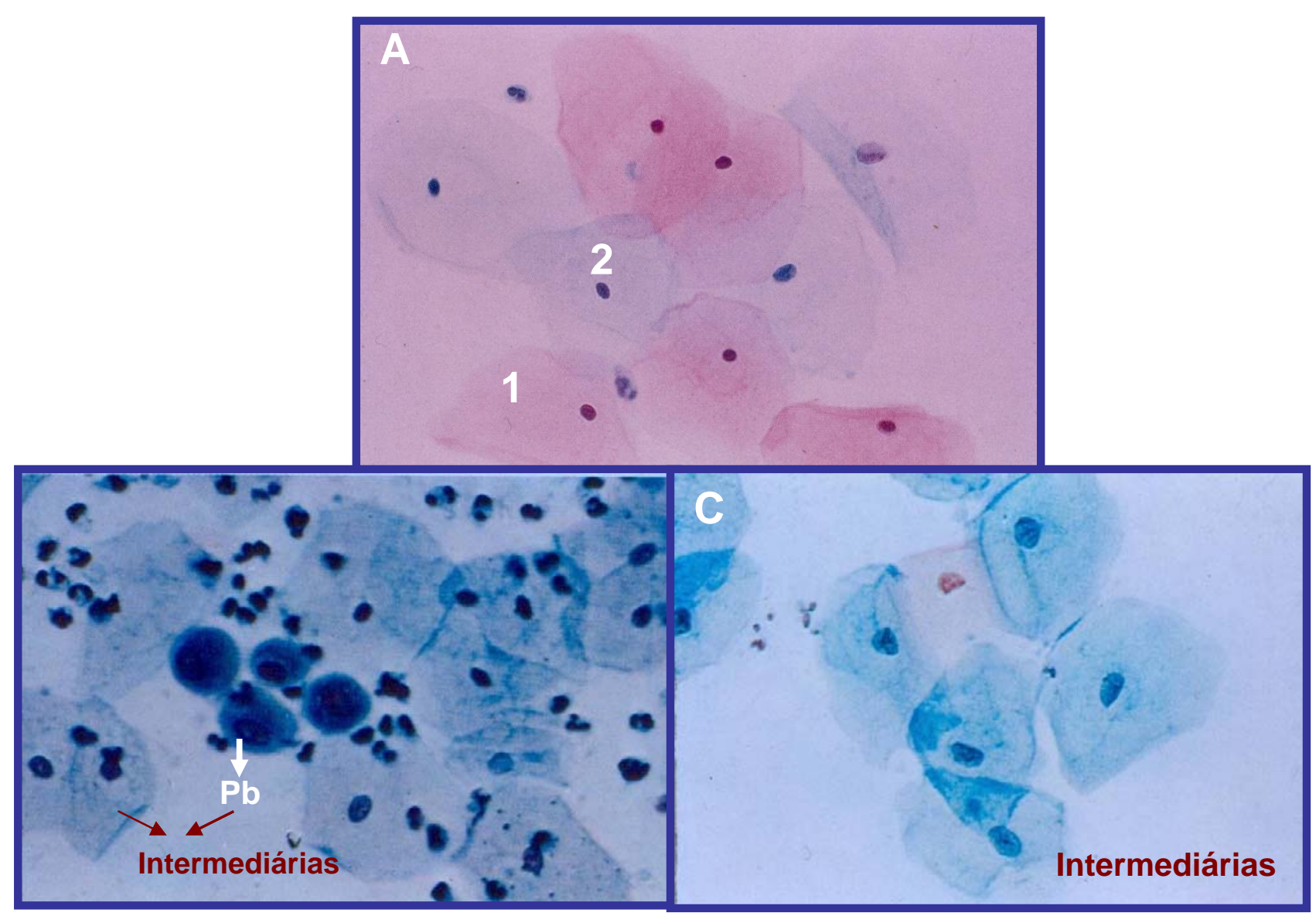

FIGURA 6 - Tipos celulares encontrados no epitélio plurestratificado pavimentoso não ceratizado de mulheres em menacme. células superficiais eosinofílias (A1), Células superficiais cianofílias (A2), células intermediárias e células parabasais $(\mathrm{Pb})$ (B) e células intermediárias (C).

Com a aproximação da menopausa, são poucos os folículos ovarianos que amadurecem e a secreção de estrógenos apresenta diminuição gradativa. Os hormônios estrógeno e progesterona são insuficientes para produzir o amadurecimento do epitélio escamoso (FIGURA 7). Na mulher na menopausa o epitélio pluriestratificado pavimentoso não ceratinizado, pela falta dos hormônios ovarianos, apresenta sinais de atrofia (FIGURA 8) (WIED \& BIBBO, 1990).

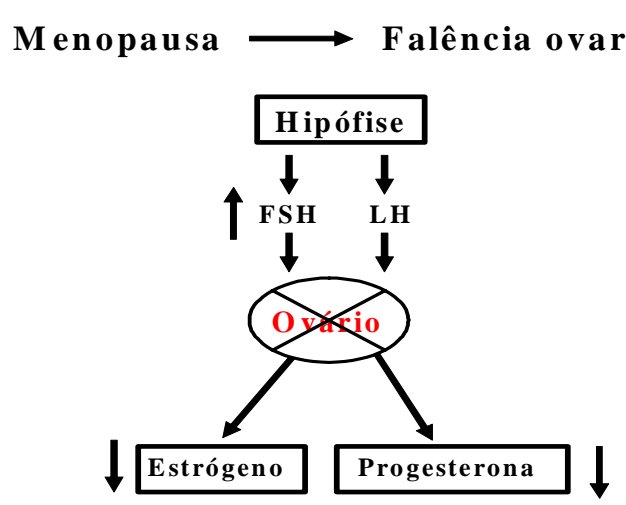

FIGURA 7 - Representação esquemática da produção hormonal da pré e pós menopausa. 


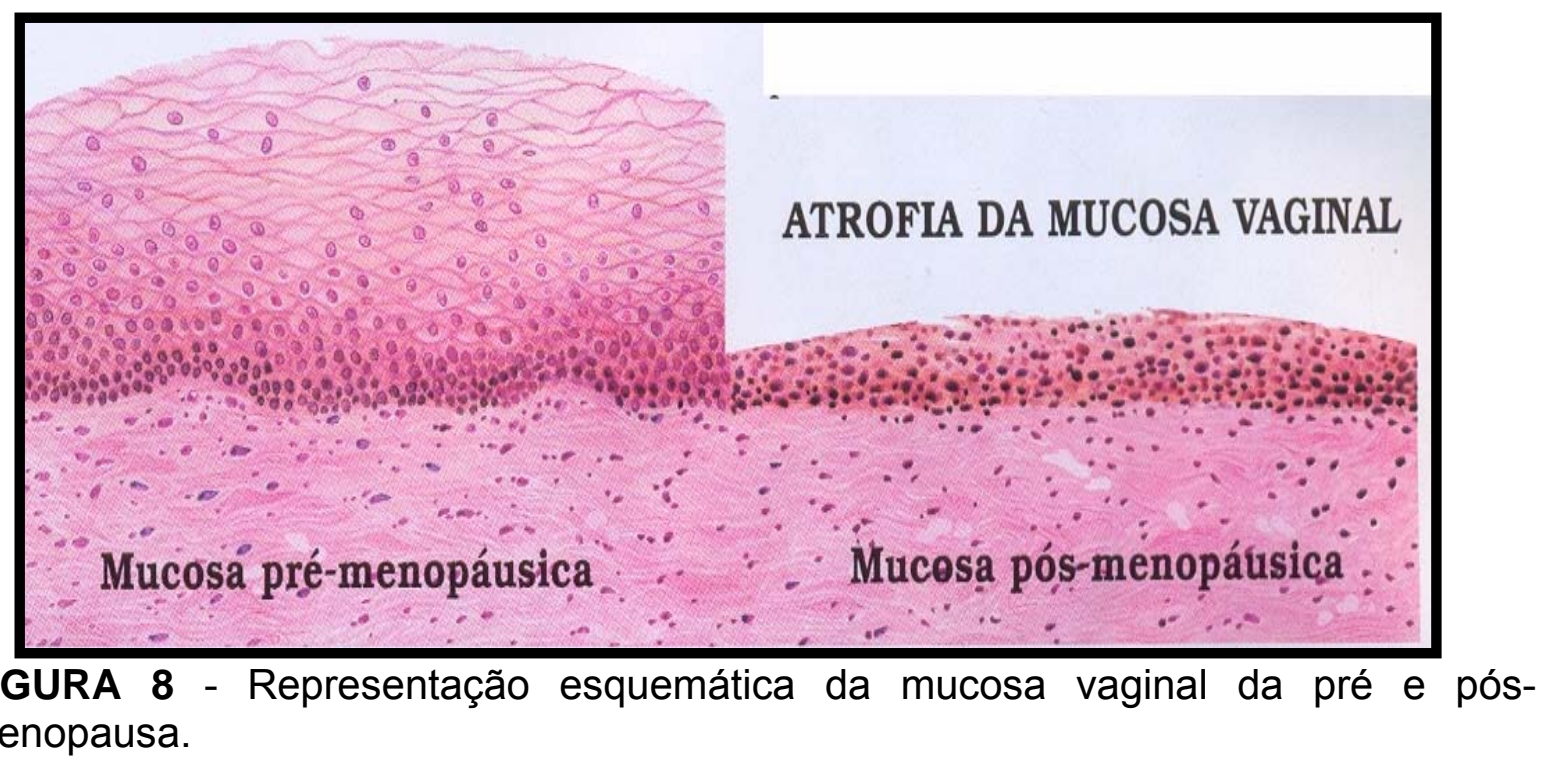

O esfregaço vaginal de mulheres na menopausa pode apresentar os seguintes padrões:

a) estrogênico: existe a possibilidade da persistência de esfregaços típicos de atividade estrogênica mesmo em mulheres sem ciclo menstrual, por ação de hormônios da córtex da glândula adrenal, ou de hormônios androgênicos.

b) misto: quando ocorre vaginite atrófica, as mudanças degenerativas no epitélio podem levar a um aumento da eosinofilia, sendo encontrados todos os tipos celulares, a saber:

1) hipotrófico: apresenta acentuada predominância de células intermediárias com grandes núcleos são células mais profundas; usualmente ovais e algumas outras com núcleos pequenos ou médios. As células intermediárias poderão surgir em grupos densos e grandes, conhecidos como grupamentos ou aglomerados da menopausa. Podem ocorrer células naviculares com depósito de glicogênio. Neste esfregaço podem ainda encontrar células superficiais. $O$ muco não é muito abundante, os leucócitos são pouco freqüentes e os Bacilos de Döederlein estão presentes em quantidades variáveis. Algumas condições podem aumentar o número de Bacilos de Döederlein nesta fase: diabetes, tratamento com corticóides ou digitálicos.

2) atrofia precoce: $50 \%$ ou mais das células são da camada parabasal que poderão ser vistas em grupamentos grandes ou pequenos; o restante das células são intermediarias. Podem ser identificadas raras células superficiais e raríssimas células superficiais eosinofílicas. 
3) atrofia tardia: próximo de $100 \%$ das células parabasais. O núcleo das células intermediárias são maiores que nos esfregaços não atróficos, pois são células intermediárias profundas e são comuns as figuras de cariorrexe e cariopicnose, assim como células metaplásicas bastante alongadas. O muco pode ser denso e abundante, podendo ser confundido com fungos, quando se dispõe em filamentos. Os leucócitos aumentam em número e podem apresentar-se degenerados. Os histiócitos podem ser freqüentes e muitas vezes multinucleados. Os Bacilos de Döederlein são raros e até ausentes (CARVALHO, 1993; HUSAIN \& BUTLER, 1992).

A atrofia vaginal, causada pela deficiência de estrógeno é uma condição comum e bem reconhecida na menopausa. Além da avaliação clínica dos sintomas e da inspeção do epitélio vaginal, é necessário um método objetivo que permita o diagnóstico e o acompanhamento de tratamento. O método inicialmente desenvolvido para avaliação do efeito estrogênico no epitélio vaginal foi a análise citomorfológica (NILSSON et al., 1995).

O esfregaço completamente atrófico apresenta células parabasais pequenas com grandes núcleos, numerosos leucócitos, alguns eritrócitos e sinais de necrose; com este aspecto é possível afirmar que não existe ação estrogênica, androgênica ou progesterônica, típico do esfregaço atrófico (FIGURA 9) (PUNDEL et al., 1968).

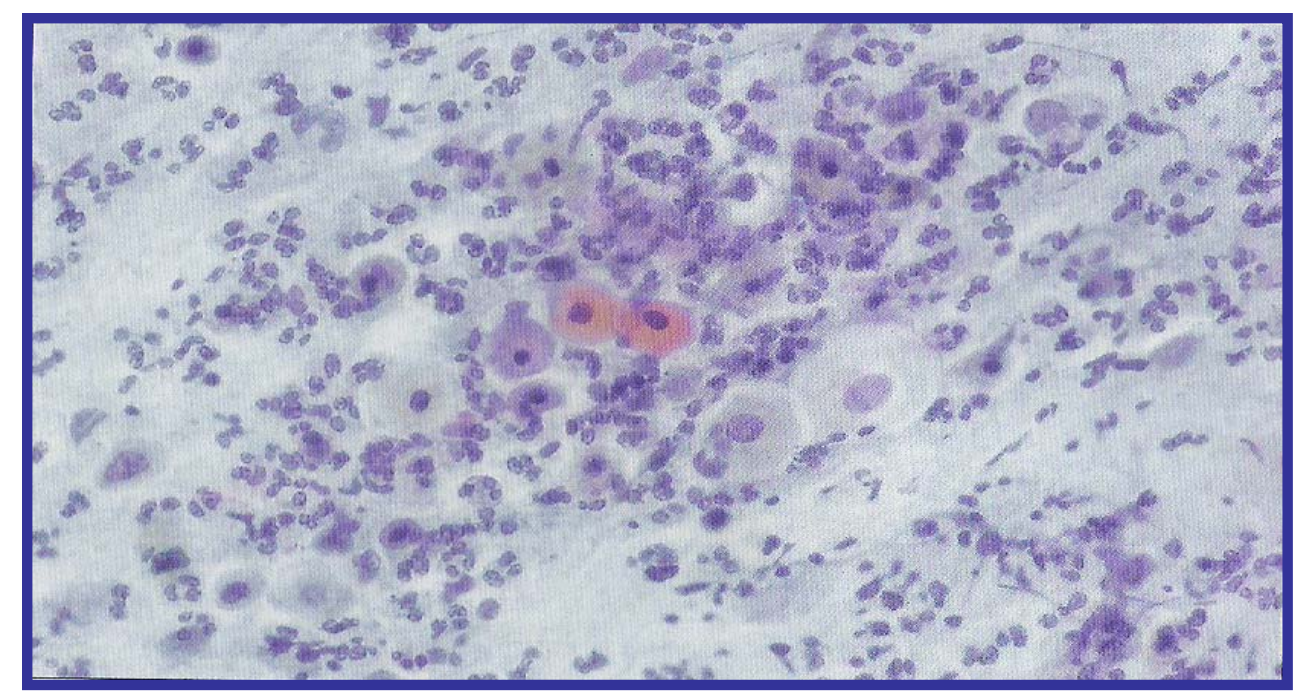

FIGURA 9 - Esfregaço vaginal do tipo atrófico, característico da pós-menopausa. 


\subsubsection{1 Índices citológicos}

Através das células descamadas do terço posterior da vagina de mulheres que não apresentam nenhum quadro de infecção vaginal, é possível avaliar a maturação do epitélio escamoso. Para tal, usa-se a determinação do índice de maturação (I.M.) ou também denominado índice de Frost, que expressa a porcentagem relativa das células parabasais, intermediárias, células superficiais cianofílicas e células superficiais eosinofílicas. Outros índices também são de grande valia na avaliação hormonal através da citologia vaginal. O índice de picnose (I.P.) representa a porcentagem das células superficiais cianofílicas somadas às eosinofílicas e o índice de eosinofilia (I.E.) expressa unicamente a porcentagem de células superficiais eosinofílicas, representando, assim, a maturação máxima do epitélio escamoso pluriestratificado não ceratinizado (AYALLA et al., 1985).

O valor de maturação (V.M.) de Meisels representa a maturação do epitélio vaginal através de um número, obtido seguinte soma [( $1 \mathrm{x}$ número de células superficiais $)+$ (0,5 x número de células intermediárias)]. Este valor também fornece uma boa avaliação hormonal da paciente (MEISELS, 1967).

Hustin \& Van Den Eynde, (1977) apresenta uma outra forma de expressar o valor de maturação que é $(V . M)=.(0,2 \times$ células parabasais $)+(0,6 \times$ células intermediárias $)$ $+(1,0 \times$ células superficiais), aplicado para porcentagem das células contadas após a contagem de 400 células por lâmina. O autor justifica esta modificação no V.M. de Meisels por considerar importante na avaliação hormonal a inclusão de células parabasais, que facilitam o acompanhamento da atrofia ou efeito da estimulação de hormônio androgênico endógeno e avaliação do efeito de substâncias estrogênicas. Assim, um V.M. de Hustin superior a 60 indica um efeito estrogênico verdadeiro e abaixo de 60 é de predominância de células intermediárias com mais ou menos células parabasais, sendo os valores mais baixos representativos de atrofia ou estimulação androgênica endógena (HUSTIN \& VAN DEN EYNDE, 1977; WOOD et al., 2006).

O uso dos índices de avaliação hormonal é útil para medir os efeitos proliferativos de substâncias administradas para corrigir distorções hormonais da paciente. 
Substâncias estrogênicas podem levar o I.P. até $80 \%$ e as substâncias androgênicas podem levar o I.P. de 5 a 20\%. Avaliar o estado hormonal da paciente através destes índices é útil também para determinar as melhores vias de administração hormonal e apresentações farmacêuticas mais eficazes. Também demonstram o início e a duração dos efeitos hormonais, realçando diferenças individuais das pacientes. Os índices fornecem valores relativos e nunca valores absolutos. Enfim, pode-se fazer o acompanhamento do tratamento hormonal comparando-se os índices de avaliação hormonal em tempos determinados (BOSCHANN, 1968).

$\mathrm{Na}$ avaliação da atividade estrogênica é satisfatório o uso do I.P. e nas alterações da gravidez é usada a combinação do I.P. com o I.E. A proliferação do epitélio vaginal e diferenciação na camada superficial podem ser observadas em casos de prolapso uterino. Em mulheres castradas com flora vaginal cocóide os I.E. e I.P. estão mais elevados. Exposição à altas doses de estrogênio (tumores ovarianos secretores de estrogênio) podem levar a não resposta do epitélio vaginal a novas aplicações do estrogênio, o mesmo acontecendo com exposição à radiação. O tratamento com digitálicos parecem induzir efeitos estrogênicos. Portanto diferentes estímulos hormonais podem levar a padrões de esfregaços vaginais semelhantes (FERIM, 1968).

\subsubsection{Urocitograma}

O urocitograma é uma técnica útil em casos no qual o colpocitograma é contra indicado, devido a metrorragia, infecções vaginais ou em citologia de mulheres grávidas próximas ao parto (CODECIDO, 1961).

Algumas células descamadas do corpo, como as do trígono uretral, da mucosa bucal, nasal e da conjuntiva ocular respondem de forma satisfatória às variações dos hormônios sexuais de modo semelhante ao epitélio pluriestratificado pavimentoso não ceratinizado, da ectocérvice e vagina (AYALA et al., 1985). Assim, a análise dessas células descamadas fornecem dados sobre a situação hormonal da mulher, sendo possível investigar questões hormonais sem, necessariamente, analisar os epitélios vaginais. 
Comparando colpocitograma e urocitograma, após administração de estriol injetável (1 ou $2 \mathrm{mg} / \mathrm{dia}$ ) houve resposta significativa, com relação ao I.P. e ao I.E., sendo este último menor no urocitograma (LENCIONI et al., 1963).

A técnica do urocitograma é uma alternativa para determinação de citologia hormonal muito útil nas pacientes menopausadas com atrofia do epitélio vaginal, na qual a coleta convencional do esfregaço vaginal é desconfortável. A representatividade celular é satisfatória e equivalente na urina quando comparada à secreção vaginal. É pouco usado devido a facilidade dos métodos de dosagens hormonais por quimioluminescência e radioisótopos, porém a vantagem do urocitograma é a possibilidade da citologia hormonal seriada em todo o ciclo menstrual (LENCIONI et al., 1963).

\subsection{Avaliação dos sintomas da menopausa}

Devido às dificuldades de mensurar os sinais e sintomas da menopausa, os efeitos qualitativos e subjetivos têm sido quantificados por vários autores possibilitando a investigação destes dados, das mulheres nesta fase de suas vidas, usando ferramentas da estatística não paramétrica (TRIOLA, 1999).

Testando 20 grupos de mulheres menopausadas medicadas com substâncias estrogênicas e um grupo tratado com placebo, foi determinado o índice de Kuppermann que leva em conta onze queixas bastante comuns na menopausa. As queixas investigadas pelo índice são ondas de calor, parestesia, dormência, formigamento, insônia, nervosismo, melancolia, vertigem, preguiça ou fadiga, artralgia ou mialgia, cefaléia e palpitação. Os achados subjetivos são convertidos em valor numérico baseado na gravidade relatada pela paciente, sendo zero quando ausente, 1 quando é leve, 2 para as queixas moderadas e 3 para quando a paciente relata a queixa como acentuada, a soma dos números funciona como índice que mede a gravidade do sintoma da menopausa. Existe uma valorização principalmente das ondas de calor, parestesia, insônia e nervosismo (KUPPERMANN et al., 1953). 
Supondo que os sintomas psicodinâmicos poderiam melhorar com psicoterapia e sedação com barbituratos, um grupo de pesquisadores avaliou o efeito de substâncias estrogênicas e não estrogênicas, incluindo etinilestradiol, estrogênio eqüino conjugado, Vitamina $E$, fenobarbital e um grupo placebo. A melhora dos sintomas da menopausa foi de aproximadamente $93 \%$ com etinilestradiol, $91 \%$ no grupo tratado com estrogênio eqüino conjugado, $43 \%$ nas mulheres que receberam fenobarbital, $26 \%$ com vitamina E e $33 \%$ no grupo placebo. A partir deste estudo estabeleceu-se então o índice de Blatt-Kuppermann ou, simplesmente, índice de Kuppermann, como é conhecido até hoje (BLATT et al., 1953).

O índice de Kuppernann não investiga sintomas como ressecamento vaginal ou sintomas ligados à sexualidade como a diminuição da libido e dispareunia, também não leva em conta nenhum dado psico-sócio-cultural. Além disso, uma outra crítica do uso deste índice é a valorização de queixas que não tem o mesmo peso para todas as mulheres e nem em todas as populações femininas. Com os avanços da matemática e bioestatística poder-se-ia validar a escala e adequá-la aos padrões atuais, com uma justificativa estatística satisfatória (ALDER, 1998).

Um questionário com 28 sintomas e que inclui os sintomas da lista do índice de Kuppermannn, dividido em 12 queixas somáticas, 5 psicossomáticas e 11 queixas psicológicas foi aplicado a 460 mulheres de idades entre 13 e 64 anos, distribuídas em 5 faixas etárias. As adolescentes tiveram mais queixas psicológicas e as mulheres na menopausa apresentaram mais queixas somáticas e psicossomáticas, tendo como causa as modificações biológicas e o stress psico-social na adolescência e na menopausa (NEUGARTEN \& KRAINES, 1965).

Outro questionário enfocando a melhora do relacionamento sexual enfocando: satisfação com a freqüência, prazer, excitação, orgasmo, ressecamento vaginal e dispareunia, denominado McCoy's Sex Scale questionnarie, foi aplicado em 315 mulheres, comparando os efeitos da tibolona e acetato de estradiol-noretisterona, após 24 e 48 semanas de tratamento. Neste estudo o uso da tibolona melhorou a satisfação, a freqüência e o prazer nas relações sexuais, além de provocar menor número de casos de sangramento (NATHORST-BÖÖS \& HAMMAR, 1997). 


\subsection{Terapia de Reposição Hormonal (TRH)}

Vários sintomas da menopausa podem ser solucionados com o uso da TRH que consiste na administração de estrógeno isolado ou em associação com progestágenos. Há vários tipos de esquemas terapêuticos para a TRH. Para mulheres histerectomizadas, geralmente usa-se o estrógeno isolado de forma contínua ou cíclica e nas mulheres com útero intacto usa-se a associação de estrógeno e progestágeno. $\mathrm{Na} \mathrm{TRH}$ os estrógenos naturais, tais como estrógeno eqüino conjugado (EEC), 17 $\beta$-estradiol, valerato de estradiol são os mais usados porque tem menor ocorrência de efeitos colaterais (CHRISTIANSEN, 2001).

O estrógeno pode ser administrado por várias vias. A via oral diminui a biodisponibilidade do hormônio, uma vez que ocorre efeito de primeira passagem no fígado, necessitando aumento da dose. A via transdérmica parece ser a mais segura, no entanto, pode causar irritação da pele; a via vaginal tem ação local, sendo efetiva contra o ressecamento vaginal e a via intranasal parece ser uma opção simples e de fácil administração (AL-AZZAWI, 2001).

O estrógeno além de atuar no trato reprodutivo, atua no cérebro aumentando o fluxo sangüíneo e melhorando a capacidade cognitiva; na pele e mucosas aumentando a quantidade de colágeno, diminuindo assim os sintomas urogenitais e o ressecamento vaginal; no tecido vasomotor produzindo óxido nítrico e atuando sobre os canais de cálcio, promovendo vasodilatação (GENAZZANI \& GAMBACCIANI, 2001).

Uma vez que o uso de estrógeno isolado durante a menopausa pode causar hiperplasia endometrial, os progestágenos são administrados em associação com o estrógeno, para prevenir este efeito. A ação dos progestágenos inclui proliferação e diferenciação endometrial, implantação do ovo, ovulação, crescimento e diferenciação das glândulas mamárias. Assim, os progestágenos em associação com os estrógenos, seja em formulações contraceptivas ou na terapia de reposição hormonal, atuam sinergicamente para produzir os menores efeitos colaterais à paciente. Os progestágenos mais usados são os derivados da 17ßhidroprogesterona (acetato de ciproterona, acetato de medroxiprogesterona), 
derivados da 19-norprogesterona (trimegestone) e derivados da 19-nortestosterona (noretisterona, noretinodrel) (SCHINDLER , 2003).

Apesar dos benefícios que a TRH podem proporcionar, a terapia estroprogestiva está envolvida no aumento do risco de eventos tromboembólicos, câncer de mama e de endométrio, sendo estes últimos as principais causas de não adesão e descontinuidade do tratamento (WHI, 2002). Existe ainda a contra-indicação de terapia estroprogestiva para pacientes com história familiar de câncer hormônio dependente, de doenças hepáticas, cardiovasculares e tromboembólicas confirmadas (NAMS, 2004).

Existem alternativas não hormonais como cremes vaginais à base de polycarbophil que é um bioadesivo insolúvel em água. Esse adesivo retém água e consegue hidratar a mucosa vaginal, lubrificando-a e diminuindo a dispareunia (dor, irritação). Além disso, restaura o $\mathrm{pH}$ vaginal para os valores anteriores da menopausa, aumentando a área celular (quando medidas pela citomorfometria) apesar de não chegar a alterar os I.M.s (VAN der LAAK et al., 2002).

\subsubsection{Avaliação Hormonal de Terapia Estroprogestiva pela Colpocitologia}

Hustin \& Van Den Eynde (1977) investigaram o V.M. do epitélio vaginal de 263 mulheres menopausadas ou histerectomizadas após tratamento com diferentes esquemas terapêuticos, sendo eles etinilestradiol (114 pacientes, com a dose $25 \mu \mathrm{g}$, 1 a 3 vezes por semana); valerato de estradiol (39 pacientes, com a dose de $2 \mathrm{mg}$ em dias alternados, ou a cada 3 dias); dienestrol (20 pacientes, com a dose de 2,5 mg em dias alternados), estriol (28 pacientes, com doses baixas de $250 \mu \mathrm{g}$ diárias e doses altas de $2 \mathrm{mg}$ em dias alternados); benzoato de estradiaol (16 pacientes, com a dose de $10 \mathrm{mg}$, via intramuscular mensalmente); valerato de estradiol (4 mg + enantiato de testosterona na dose de $65 \mathrm{mg}$ em 24 pacientes, via intramuscular mensalmente) e dietil-estilbestrol (22 pacientes, na dose de $100 \mathrm{mg}$, em "pellets" subcutâneos). Após 15 dias o V.M. foi $68,5 \pm 9,5$ para o grupo tratado com etinilestradiol; 69,6 \pm 10,7 no grupo tratado com valerato de estradiol; 64,0 $\pm 3,9$ nas pacientes tratadas com dienestrol; 25,0 \pm 5,0 naquelas tratadas com $2 \mathrm{mg}$ de estriol 
e 64,4 $\pm 6,1$ para a dose maior de $2-6 \mathrm{mg}$ do mesmo. As mulheres tratadas com dietilestilbestrol subcutâneo tiveram o V.M. de 75,8 $\pm 8,5$, as que receberam benzoato de estradiol intramuscular $67,7 \pm 7,1$ e, por fim, o VM foi de $62,3 \pm 6,6$ após o tratamento com valerato de estradiol + enantiato de testosterona pela via intramuscular. Foi demonstrado um efeito estrogênico muito baixo nas doses baixas de estriol.

Ainda sobre o estudo acima, observou-se que o efeito do dietilestilbestrol subcutâneo permaneceu alto até dezoito meses após o término do tratamento, sendo o V.M. médio de 26,3 para o estriol em doses baixas ou em doses altas e para os outros medicamentos a diminuição foi mais lenta, após 15 dias de encerramento do tratamento, ainda mantinha um V.M. relativamente alto. A dose de etinilestradiol, valerato de estradiol e dimestrol que aumentou a maturação vaginal é próxima da dose que provocou estimulação endometrial o que não ocorre com o estriol que age na maturação vaginal na dose de 33-66 $\mu \mathrm{g} / \mathrm{kg}$ de peso/semana e a dose de estimulação endometrial é de $166 \mu \mathrm{g} / \mathrm{kg} / \mathrm{semana}$ (HUSTIN \& VAN DEN EYNDE, 1977).

O efeito de hormônios combinados (valerato de estradiol 2 mg e levonorgestrel 0,15 mg) por seis meses foi avaliado em 36 mulheres em pré e pós-menopausa, sobre os sintomas vaginais, $\mathrm{pH}$, citologia e I.M. Observou-se diminuição do $\mathrm{pH}$, aumento do índice de cariopicnose, aumento do I.M., melhoria na morfologia das células vaginais e dos sintomas (MANONAl et al., 2004).

Em outro estudo envolvendo 1028 mulheres de diferentes etnias, em 11 países asiáticos, tratadas por 24 semanas com 3 concentrações de estrógeno eqüino conjugado/acetato de medroxiprogesterona $(0,625 / 2,5 ; 0,45 / 1,5$ e 0,3/1,5 mg, respectivamente), foram avaliados os efeitos na menopausa, através de um questionário enfocando 18 sintomas e a atrofia vaginal avaliada pelo IM. Os sintomas vasomotores diminuíram nos grupos étnicos de forma semelhante nas 3 doses e todas as doses estimularam a maturação do epitélio vaginal não havendo diferença estatisticamente significativa entre os grupos, mas o valor das células 
superficiais variou $28,2 \%$ na dose de $0,3 / 1,5 \mathrm{mg} ; 30,7 \%$ na dose $0,45 / 1,5 \mathrm{mg}$, e $32 \%$ na dose 0,625/2,5 mg (TAN et al., 2005).

Além disso, foi testado em mulheres menopausadas com sintomas vasomotores (de moderados a graves) o uso de anel intravaginal contendo estradiol por 13 semanas. Os anéis liberavam $50 \mathrm{mg} / \mathrm{dia}$ do hormônio num grupo de 113 mulheres e 100 $\mathrm{mg} /$ dia em outro grupo com 112 participantes. O grupo placebo foi composto por 108 mulheres usando anel intravaginal sem o medicamento. A avaliação da eficácia, tolerabilidade e aceitação foi feita pelo uso de questionários às pacientes para avaliar sintomas urogenitais e um outro sobre a aceitação do uso do anel. Para a inclusão das pacientes no estudo, foram feitos exames físicos, teste imunológico para gravidez, medidas dos sinais vitais e do peso, exames hematológicos e bioquímicos no sangue, mamografia, atrofia vaginal, biópsia uterina para mulheres com útero intacto e coleta do colpocitograma, para determinação do V.M. de Hustin. Os sintomas vasomotores regrediram significativamente nos 02 grupos tratados e houve uma tendência à melhora nos sintomas urogenitais das pacientes medicadas. Para a atrofia vaginal, encontrou-se melhora significativa no I.M. comparando com placebo (SPEROFF, 2003).

Sankar et al. (2003) avaliaram o efeito da reposição hormonal feita através de anel intravaginal contendo $2 \mathrm{mg}$ de $17 \beta$-estradiol, programado para liberar 6,5 a 9,5 $\mu \mathrm{g} / \mathrm{dia}$. Com este tratamento, observou-se alívio dos sintomas subjetivos e objetivos da deficiência de estrógenos, redução no pH vaginal em torno de 5,5 nas mulheres menopausadas e não se observou aumento de proliferação endometrial.

Outro estudo avaliou o efeito semelhante ao efeito do estrogênio provocado pelo tamoxifeno, medicamento usado como terapia adjuvante em mulheres com câncer de mama. Paral tal, o tamoxifeno foi administrado em 43 mulheres $(20 \mathrm{mg} / \mathrm{dia})$ e 10 mulheres (40 mg/dia) por período de 6 a 95 meses (em média 32 meses) e comparado com grupo controle. As pacientes que participaram deste estudo, apresentavam câncer de mama e estavam na pós-menopausa, o grupo controle foi constituído por mulheres com câncer de mama, também na pós-menopausa, que não receberam tratamento com tamoxifeno. No grupo tratado $11 \%$ dos esfregaços 
apresentaram atrofia, $65 \%$ efeito estrogênico moderado e $24 \%$ com forte efeito estrogênico. No grupo que não recebeu o medicamento (controle) observou-se 51\% de atrofia, $42 \%$ efeito estrogênico moderado e $7 \%$ com forte efeito estrogênico (LAHTI et al.,1994).

Yildirim et al. (2004), trabalhando com um grupo de 60 mulheres menopausadas, testaram em 30 delas vitamina D (1,25 diidroxicolecalciferol) na concentração 500 $\mu \mathrm{g} /$ dia e 30 mulheres não receberam medicamento. Os sintomas de atrofia vaginal foram determinados por questionário de cinco queixas (ressecamento vaginal, irritação, prurido, disúria e dispareunia), exame físico e I.M. Com relação aos sintomas não houve grande diferença entre os 02 grupos. Porém, no grupo tratado com vitamina $D$ foi observado um significativo aumento das células superficiais 35,3 $\pm 2,5 \%$ e no grupo placebo $5,4 \pm 7,5 \%$, aumento das células intermediárias $45,7 \pm$ $7,2 \%$ no grupo que recebeu a vitamina $D$ e no grupo placebo $30,6 \pm 8,5 \%$. Comparando as células parabasais e basais houve diminuição no grupo tratado de $21,0 \pm 1,5 \%$ e no grupo placebo de $64,0 \pm 5,4 \%$. Provavelmente a ligação da vitamina $D$ a receptores no epitélio escamoso da vagina atuou no crescimento e diferenciação do epitélio vaginal.

O efeito de creme vaginal à base de polycarbophil também foi avaliado e, após o tratamento, encontrou-se diminuição da dispareunia (dor, irritação), restauração do $\mathrm{pH}$ vaginal para valores anteriores da menopausa, aumento da área celular após 12 semanas de tratamento de $3248 \pm 1371$ antes para $3586 \pm 1418$ após, determinado pela citomorfometria. Os resultados do V.M. pela análise citomorfométrica foi de 44,7 $\pm 24,3$ antes para 45,6 $\pm 22,4$ após o tratamento e através da análise manual obtevese $32,5 \pm 18,9$ antes e 34,9 $\pm 16,5$ após o tratamento. A porcentagem de células parabasais variou pela análise citomorfométrica de $36,8 \pm 32,5$ para 34,1 $\pm 29,5$ e da análise manual obteve-se variação, antes do tratamento, de 35,5 \pm 37,5 para 31,0 \pm 32,2 após o tratamento. As células intermediárias variaram, pela análise citomorfométrica, de 36,9 $\pm 27,2$ antes do tratamento para 40,5 $\pm 22,3$ após o tratamento. Através da análise manual obteve-se variação de 64,1 \pm 37,2 antes do tratamento para $68,2 \pm 31,7$ após o tratamento. A porcentagem de células 
superficiais variou de $26,3 \pm 22,1$ para $25,4 \pm 19,4$ pela análise citomorfométrica e de 0,4 $\pm 18,9$ antes do tratamento para 34,9 \pm 15,5 após o tratamento (VAN der LAAK et al., 2002).

Apesar da existência de diversos estudos demonstrando os benefícios da terapia estroprogestiva na melhora da maturação epitelial e dos sintomas da menopausa, principalmente, fogachos, suores noturnos, perda da libido, incontinência urinária e dispareunia, devido ao aumento dos níveis hormonais, existe, por outro lado, grandes estudos mostrando aumento do risco de câncer de mama, eventos tromboembólicos, bem como a existência de diferentes efeitos colaterais neste tipo de terapia (WHI, 2002). Tais estudos têm contribuído para a busca de terapias que possam melhorar os sintomas da menopausa sem causar risco à vida das pacientes.

O ensaio clínico controlado utilizando estrógeno associado a progestágeno para a prevenção secundária de doenças coronarianas em mulheres na pós-menopausa (HERS - Heart and Estrogen/Progestin Replacement Study) avaliou mulheres na pós-menopausa com útero íntegro e com estabelecida doença coronariana, as quais foram tratadas com $0.625 \mathrm{mg}$ de estrógeno eqüino conjugado (EEC) associado 2.5 $\mathrm{mg}$ de acetato de medroxiprogesterona (AMP) ambos diariamente e comparada com um grupo placebo, por um período de 4.1 anos. Os resultados mostraram que o grupo tratado com TRH não apresentou redução nas doenças coronarianas e houve um aumento dos eventos tromboembólicos e doenças vesiculares (HURLEY et al., 1998).

\subsection{Fitoestrógenos}

$\mathrm{Na}$ busca de terapias alternativas para combater os sintomas indesejáveis da menopausa e menores efeitos colaterais investiga-se a reposição hormonal com fitoestrógenos. Os fitoestrógenos são compostos não-esteroidais, que recebem esta denominação por se ligarem a receptores de estrógeno e serem compostos naturalmente encontrados em alguns vegetais (KUIPER et al., 1998). A isoflavona pode ser extraída da soja (Glycine max), cimifuga racemosa (planta de origem americana) e red clover (planta européia) (ALVES \& SILVA, 2003) 
Os fitoestrógenos encontrados na soja têm sido largamente estudados porque são ricos em isoflavonas. As isoflavonas possuem as mesmas propriedades dos estrógenos endógenos e assim competem com os mesmos pela ligação com os seus receptores, mimetizando o efeito dos estrógenos sobre as células. As isoflavonas podem ser consideradas agonistas dos estrógenos no sistema cardiovascular, nos ossos e no cérebro (CLARKSON et al., 2001).

As isoflavonas estão contidas nos alimentos na forma glicosilada, predominantemente como genisteína (4,5,7-triidroxiisoflavona) e daidzeína (4,7diidroxiisoflavona), e em menor quantidade, como gliciteína, formometina e biocanina A (FIGURA 10) (MURPHY et al., 1999).

Após a ingestão das isoflavonas, a daidzeína e a genisteína são metabolizadas no trato gastrintestinal. Biocanina A e formononetina são precursores metilados da genisteína e daidzeína, respectivamente; e no intestino são convertidas por bactérias em suas respectivas agliconas. A absorção das várias isoflavonas varia entre indivíduos devido às diferenças na microbiota intestinal (BECK et al., 2005).

A daidzeína pode ser transformada em diidrodaidzeína e então em O-des-metilangolensina (O-DMA) e equol; este não é metabolizado igualmente em humanos, e a capacidade individual de transformar isoflavonas em equol pode ser uma explicação para a variedade de resultados dos benefícios da dieta rica em isoflavona, do qual os produtores de equol podem ser mais beneficiados do que os não-produtores. Segundo Setchell et al. (2002) 30-50\% da população excretam equol na urina após o consumo de soja. A genisteína é metabolizada em diidrogenisteína e em 6-hidroxi-O-DMA e p-etilfenol (composto inerte).

O grau do metabolismo da isoflavona é variável entre indivíduos e é influenciado por outros componentes da dieta, por exemplo, altas quantidades de carboidratos promovem aumento na formação de equol. Esses novos compostos produzidos pelo metabolismo podem ter diferentes efeitos biológicos e maior atividade estrogênica que as isoflavonas originais (OSOSKI \& KENNELLY, 2003; BECK et al., 2005). 


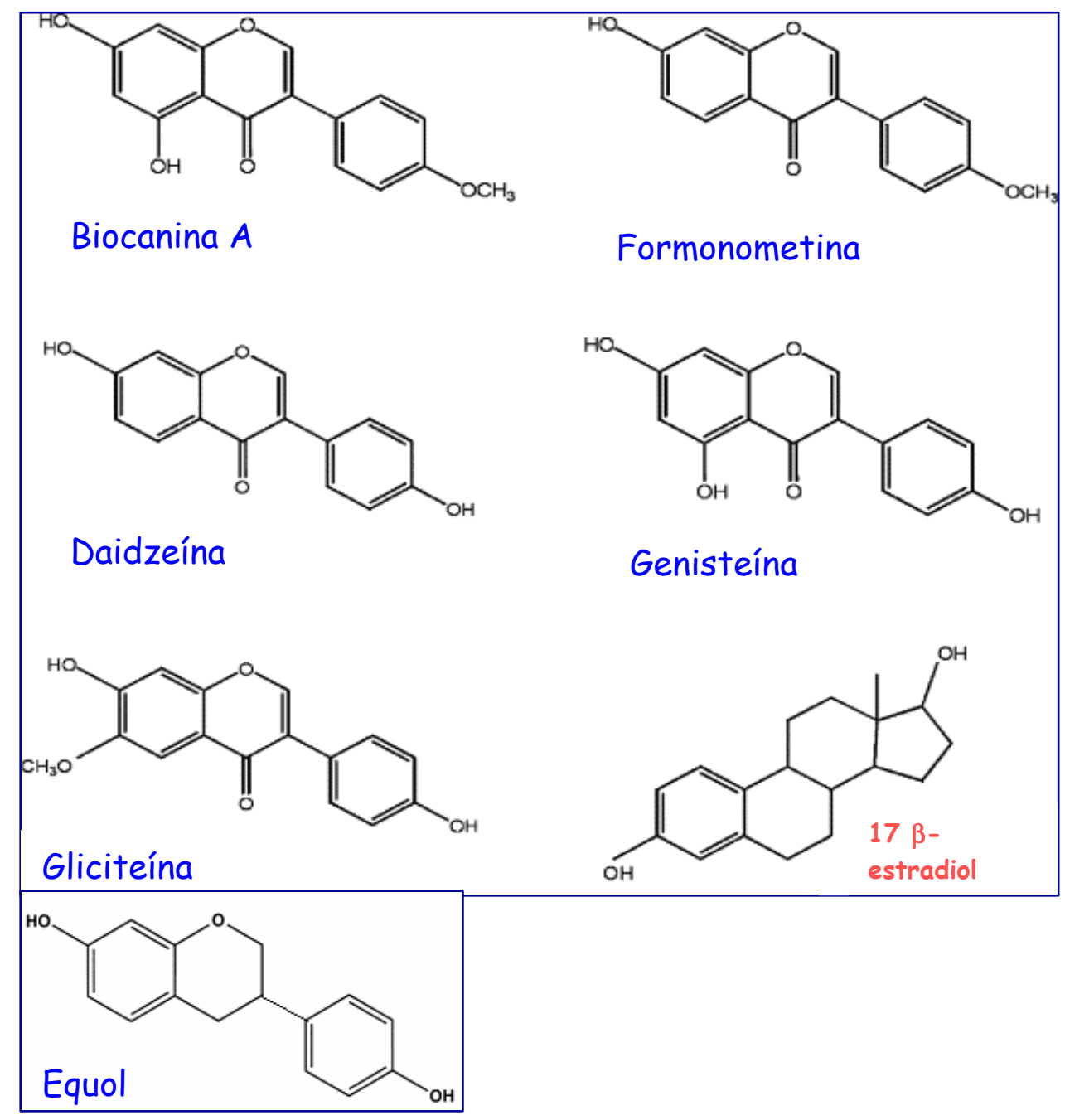

FIGURA 10 - Estrutura química dos metabólitos das isoflavona de soja, comparados com o 17ß-betaestradiol.

De forma geral, os metabólitos da isoflavona são absorvidos pelo trato gastrintestinal após uma desconjugação pela flora bacteriana, com conseqüente formação de fenóis heterocíclicos de estrutura similar ao estrogênio, o que lhes confere biodisponibilidade. Na parede intestinal e no fígado, estes compostos sofrem um processo de conjugação a proteínas, em sua maior parte, sendo enviados para a corrente sangüínea e seus sítios de atuação. Uma pequena parte é excretada pela vesícula biliar, podendo sofrer nova desconjugação e reabsorção ou serem excretados pelas fezes. O maior volume dessas substâncias é retirado do organismo por via urinária. A flora bacteriana hígida é necessária para a metabolização e conjugação das isoflavonas permitindo melhor absorção pela mucosa intestinal (ALVES \& SILVA, 2003). 
A biodisponibilidade das isoflavonas é um importante fator para a avaliação dos suplementos de fitoestrógenos. Estudos de diferentes preparações para TRH resultaram em discrepâncias entre o conteúdo de substâncias ativas determinadas por análises químicas e biológicas. O principal problema é a baixa qualidade de muitos produtos disponíveis no comércio, sendo necessário criar padrões de qualidade para tais produtos (BECK et al., 2005).

As isoflavonas exercem efeitos estrogênicos e antiestrogênicos no metabolismo, dependendo de muitos fatores, incluindo sua concentração, a concentração de estrógenos endógenos, características individuais e a fase da menopausa (BARNES, 2004; THAM et al., 1998).

Os fitoestrógenos têm também efeitos sobre diferentes enzimas envolvidas no metabolismo dos hormônios esteroidais. A aromatase, enzima que converte androstenediona em estrona e testosterona em estradiol é inibida pelos fitoestrógenos, com isso a produção endógena de estrógeno está diminuída, podendo ser responsável pelo efeito protetor contra o câncer de mama em populações com dieta rica em isoflavonas (BECK et al., 2005). As isoflavonas exercem seus efeitos inibitórios sobre muitas enzimas-chave do metabolismo esteroidal e assim diminuem o nível dos hormônios ativos nos respectivos tecidos. Muitos tipos de cânceres nos órgãos reprodutivos são dependentes de hormônios e pela diminuição dos níveis dos hormônios ativos o crescimento celular é evitado, sendo essa a base para explicar os efeitos benéficos de prevenção de câncer numa dieta rica em isoflavonas (WONG \& KEUNG, 1999).

Após a menopausa a densidade óssea freqüentemente está reduzida devido à deficiência dos hormônios ovarianos e, portanto, muitas pacientes sofrem de osteoporose. Rassi et al. (2002) investigaram os efeitos da daidzeína e do $17 \beta$ estradiol sobre o desenvolvimento e a atividade dos osteoclastos in vitro. Daidzeína inibe diferenciação de osteoclastos, da mesma forma que o $17 \beta$-estradiol, devido a um aumento na apoptose dos seus progenitores mediados pelos receptores de estrogênio. Outros estudos relataram uma estimulação dos osteoblastos pelos fitoestrógenos maior que a inibição dos osteoclastos e assim o mecanismo de ação das isoflavonas diferem dos estrógenos (WARREN et al., 2002). 
Os fitoestrógenos e, também, os estrógenos acoplam a receptores específicos presentes nos núcleos das células. A resposta tecidual pode ser estimuladora ou repressora, dependendo de diversos fatores presentes em cada célula, como o tipo de receptor ( $\alpha$ ou $\beta$ ), a prevalência de cada um nos diversos tecidos, da sua dimerização (homodímeros ou heterodímeros), do elemento de resposta estrogênica (ERE) e promotores vizinhos como TAF-1 e TAF-2 (MACHADO, 2003). TAF- 1 e TAF-2 (transcriptional activation functions 1 e 2) foram caracterizados como sendo independentes e importantes para a ação dos fitoestrógenos e dos estrógenos. $\mathrm{O}$ TAF-1 está localizado dentro da região $\mathrm{N}$-terminal A/B do receptor e é constitutivo, o TAF-2, por outro lado, tem sua atividade induzida por hormônios e está presente no domínio de ligação do hormônio (BERRY et al., 1990).

Embora a estimulação dos receptores $\beta$-estrogênicos, pelos metabólitos da isoflavona, seja muito menor que a obtida pelo estrogênio humano ou pelos estrogênios sintéticos, o uso prolongado e a ocupação gradativa e mantida dos receptores induzem um equilíbrio e um nível de estimulação mais baixo. O uso da isoflavona não tem resposta satisfatória na redução da atrofia vaginal (ALVES \& SILVA, 2003).

A isoflavona da soja promove a competição pelos receptores hormonais associada à inibição da aromatase e aumento das proteínas carreadoras de hormônios sexuais. Sua atuação seria semelhante ao tamoxifeno, exercendo uma ligação estável aos receptores $\beta$, porém com uma fraca estimulação já que não ocorre hiperplasia endometrial ou mamária. Sabe-se que a genisteína é um inibidor específico da tirosinoquinase nos receptores do fator de crescimento epidermal (EGF- Epidermal Growth Factor), topoisomerase II e histinaquinase que estão associadas à produção de tecido tumoral, à expressão de oncogenes e à angiogênese. In vitro, observa-se ainda inibição da aromatase, pela isoflavona (ou genisteína) (o que reduziria a transformação de androstenediona em estrona) e estimulação da síntese de globulina carreadora dos hormônios sexuais (reduzindo, assim, a quantidade de estrogênio endógeno disponível para ação biológica). Os efeitos da isoflavona e seus metabólitos demonstrados in vivo sugerem seu uso na prevenção de neoplasias. Para a devida ação farmacológica, os preparados de soja deverão 
apresentar um mínimo de $1,5 \%$ de isoflavonas e as doses preconizadas variam entre 40 a 160 mg por dia. Sua principal utilização é a reposição hormonal em mulheres que apresentem efeitos colaterais a TRH convencional que impossibilitem a continuidade do tratamento ou em pacientes de alto risco para neoplasia mamária e endometrial. A ipriflavona é um produto sintético, com estrutura semelhante às isoflavonas naturais, que parece exercer uma forte ação preventiva contra a perda de massa óssea sem os efeitos colaterais de outros produtos (ALVES \& SILVA, 2003).

\subsubsection{Isoflavonas e suas aplicações em menopausa}

Vários estudos apontam os efeitos benéficos das isoflavonas no perfil lipídico, na hemostasia, na melhora dos sintomas da menopausa de mulheres em pré e pósmenopausa, em mulheres com contra-indicação para TRH estroprogestiva, uma vez que estas são as maiores preocupações das mulheres nesta fase da vida.

Num grupo de 80 mulheres menopausadas, 40 delas medicadas com $100 \mathrm{mg} / \mathrm{dia}$ de isoflavona de soja e 40 usando placebo por 6 meses, foi aplicado questionário para determinar o índice de Kuppermann. Neste trabalho observou-se significativa melhora dos sintomas vasomotores. No grupo placebo observou-se uma tendência ao aumento da soma dos sintomas: antes do tratamento $40,3 \pm 1,2$, para $41,6 \pm 1,1$, após o tratamento. No grupo tratado observou-se diminuição significativa na soma dos sintomas: antes do tratamento de $44,6 \pm 1$, para $24,9 \pm 1,71$, após o tratamento. (HAN et al., 2002).

Além disso, Baird et al. (1995) pesquisaram os efeitos de uma dieta contendo aproximadamente $165 \mathrm{mg} / \mathrm{dia}$ de isoflavona. Sessenta e seis mulheres constituíram o grupo tratado e 25 mulheres o grupo controle, que consumiu dieta normal; ambos os grupos foram acompanhados por quatro semanas. Não houve variação significativa nos valores de FSH, LH, SHBG (globulina de ligação dos hormômios sexuais) e estradiol, antes e após o consumo de dieta rica em soja ou dieta comum. Nas mulheres que usaram isoflavona em $68 \%$ das citologias não houve alteração, em $19 \%$ houve um acréscimo e em $13 \%$ houve decréscimo na porcentagem de 
células superficiais contadas. No grupo controle, em $71 \%$ não houve alteração, houve decréscimo em $21 \%$ e um acréscimo em $8 \%$ na porcentagem das células superficiais. Observou-se significância $(P=0,06)$, na proporção de aumento $(19 \%$ e $8 \%$ ), comparado com o decréscimo (13\% e 21\%) das células superficiais nas mulheres que usaram isoflavona. A mudança no valor das células intermediárias e parabasais não revelou significância. O V.M., que o autor relata como porcentagem de células superficiais somadas à metade da porcentagem de células intermediárias, apresentou pequena variação. Para o grupo controle, houve uma variação de 16,1 \pm 18,8 , antes do tratamento, para 14,2 $\pm 18,4$, depois do tratamento. O grupo que consumiu isoflavona apresentou aumento de $14,6 \pm 18,7$, antes do tratamento, para $17,4 \pm 22,2$ após o tratamento.

Em um estudo envolvendo 146 mulheres pós-menopausadas, investigou-se o efeito de 2 cápsulas diárias contendo cada uma $17,5 \mathrm{mg}$ de extrato de soja $(5 \%$ de daidzeína, $3 \%$ de gliciteína e $1,5 \%$ de genisteína), durante 4 meses sobre os sintomas do climatério. Para tal, usou-se um questionário sobre sintomas, sendo as respostas graduadas 0 (ausentes) a 100\% (fortes). Investigou-se número de ondas de calor/dia, perturbações do sono, ansiedade, depressão, ressecamento vaginal, diminuição da libido e dores ósseas. Apenas $5,48 \%$ das mulheres não responderam ao tratamento, $80,82 \%$ das mulheres tiveram $62,3 \%$ de diminuição das ondas de calor de 82,73 $\pm 17,14$ (antes) para 36,33 $\pm 27,71$ (depois); perturbações do sono de $61,46 \pm 32,61$ (antes) para 32,66 \pm 30,92 (após); ansiedade de 59,53 \pm 27,81 (antes) para 33,00 \pm 29,72 (após); depressão de 49,86 \pm 30,67 (antes) para 28,83 \pm 27,89 (após); o ressecamento vaginal de 52,48 \pm 33,86 (antes) para 31,83 \pm 29, 09 (após); diminuição da libido de 57,77 \pm 33,56 (antes) para 43,17 \pm 34,50 (após); dores ósseas de 54,42 \pm 35,37 (antes) para 36,17 \pm 34,21 (após) (ALBERT et al., 2002).

Outro estudo contou com a participação de 18 mulheres, foram testados 3 períodos de dieta, com 93 dias cada período e intervalo de 23 dias entre os períodos. A dieta baseava-se em um suplemento alimentar à base de concentrado protéico de soja, contendo quantidades crescentes de isoflavona. A dieta controle continha baixa concentração de isoflavona $(0,11 \pm 0,01 \mathrm{mg} / \mathrm{kg}$ de peso, equivalendo a $7,1 \pm 1,1$ 
$\mathrm{mg} / \mathrm{dia})$, enquanto as outras duas continham baixa $(1,00 \pm 0,01 \mathrm{mg} / \mathrm{kg}$ de peso, equivalendo a $65 \pm 11 \mathrm{mg} / \mathrm{dia})$ e alta $(2,00 \pm 0,02 \mathrm{mg} / \mathrm{kg}$ de peso, equivalendo a 132 $\pm 22 \mathrm{mg} / \mathrm{dia}$ ) concentração de isoflavona. Amostras de sangue foram colhidas no início e no final de cada período de dieta e realizou-se dosagem de estrogênios, androgênios, gonadotrofinas, SHBG, prolactina, insulina, cortisol, hormônios tireoideanos e citologia vaginal. Antes do início e no final do tratamento foram feitas biópsias endometriais. O valor de maturação, avaliado antes do início do tratamento foi $38,4 \pm 4,9$. Ao consumir dieta controle muito pobre de isoflavona o valor de maturação foi $41,3 \pm 4,0$ e na dieta pobre o valor de maturação foi de $36,4 \pm 4,8$; enquanto na dieta rica o valor de maturação obtido foi de $35,0 \pm 4,6$. Não houveram diferenças significativas nos resultados de biópsias de endométrio e nem no valor de maturação, antes e depois do tratamento e algumas variações pouco significativas dos outros parâmetros medidos antes e depois das 3 dietas. Na dieta rica em isoflavona houve um aumento significativo de SHBG (DUNCAN et al., 1999).

Em adição, Xu et al. (2000), usando as mesmas pacientes do estudo anterior, investigaram 10 fitoestrógenos e 15 estrógenos endógenos e seus metabólitos na urina pelo método de espectrofotometria de massa, no início e no final de cada uma das 3 dietas. As amostras de urina foram coletadas 3 dias antes do início da dieta para determinação basal e 91-93 dias para cada período de dieta. Conforme esperado, houve aumento da excreção urinária de isoflavonóides após o consumo de 7, 65 ou 132 $\mathrm{mg} / \mathrm{dia}$ de isoflavona da soja de forma dose-dependente. Durante a dieta, a excreção de genisteina, daidzeina, O-DMA e equol variou de 2, 5, 10 e 120 vezes, respectivamente. $O$ equol apresentou a variabilidade, porque apenas 6 das 18 mulheres eliminaram quantidades significativa de equol, esse dado é consistente com outras observações que mostram que apenas 30 - 40\% de indivíduos produzem grandes quantidades de equol após consumo de soja. A variação observada entre as mulheres provavelmente está associada a diferenças na colonização da microflora intestinal, que é responsável pela produção das enzimas que metabolizam a isoflavona. No entanto, a observação mais importante deste estudo, foi que nos grupos tratados com isoflavona, houve decréscimo nos metabólitos do estrogênio com características potencialmente carcinogênicas e ocorreu aumento dos metabólitos hidroxilados, aos quais é conferido um fraco e benéfico efeito estrogênico. 
Uesugi et al. (2003) realizaram outro estudo, usando grupo de 22 mulheres pósmenopausadas, no qual 11 receberam duas doses diárias de $30,9 \mathrm{mg}$ de isoflavona/dia e 11 receberam dextrina na mesma dose, por 3 meses, como grupo placebo. A citologia hormonal foi coletada antes e após o tratamento. As alterações observadas no grupo tratado foram significativas, com diminuição no número de células parabasais de $58,2 \% \pm 12,4 \%$ para $24,1 \% \pm 8,7 \%$ e o aumento das células intermediárias de $25,0 \% \pm 10,7 \%$ para $63,7 \% \pm 10,7 \%$. No grupo placebo não houve alterações significativas.

Atualmente, existe grande interesse em terapias hormonais alternativas naturais, por isso, muitos grupos têm trabalhado com animais de laboratório investigando os efeitos das isoflavonas. Seu efeito estrogênico, em animais, demonstrou alterar a citologia vaginal, proliferar glândula mamária e aumentar peso uterino (WANG et al., 1995; SANTELL et al., 1997).

Durante dois meses, Tansey et al. (1998) alimentaram ratas de 40 dias, castradas, com 12 tipos de dieta, com 8 a 12 animais por cada grupo. A primeira dieta era enriquecida com baixo teor de isoflavona (11,6 mg/1800 calorias), a segunda continha alto teor de isoflavona $(117,8 \mathrm{mg} / 1800$ calorias), outro grupo recebeu tratamento com baixo teor de estrogênio equino conjugado (0,313/1800 calorias), 0 quarto grupo foi tratado com alto teor de estrogênio eqüino conjugado $(0,625 / 1800$ calorias) e a quinta dieta foi baseada em ração enriquecida com caseína (grupo placebo). Além disso, os grupos $6,7,8$, e 9 receberam isoflavona e estrógeno eqüino conjugado; os grupos 10 e 11 receberam caseína e estrógeno eqüino conjugado e o grupo 12 foi formado por ratas não castradas. As citologias foram colhidas na semana do início e na última semana do tratamento diariamente, por aspiração. Não foram evidenciados efeitos estrogênicos nos grupos tratados com caseína e isoflavona de soja, porém os animais tratados com estrogênio eqüino conjugado apresentaram efeitos estrogênicos na citologia vaginal.

Num outro estudo de Cline et al. (1996), um grupo de 40 macacas castradas a mais de um ano, 13 receberam caseína (placebo), 12 receberam 26,6 mg de genisteina /dia (equivalente a 99,7 mg/dia em mulheres) e 15 receberam estrógeno eqüino conjugado na dose de $166 \mu \mathrm{g} / \mathrm{dia}$ (equivalente a 0,625 mg/dia em mulheres) em suas 
dietas. Calculando-se o I.M. de Hustin [I.M. = 0,2 x \% células parabasais $+(0,6 \%$ de células intermediarias $)+(\%$ de células superficiais $)$ ]. Encontraram-se resultados não estatisticamente significativos na comparação entre os grupos.

Ratas wistar, divididas em 4 grupos, sendo o grupo placebo alimentado com ração normal e os outros grupos tratados, desde o desmame até o término do estudo, com ração contendo 0,$7 ; 1,2$ ou 2,4 \% de extrato de soja na ração. Determinou-se o dia da ovulação das ratas e alojaram-se machos e fêmeas, sendo considerado o primeiro dia da gestação quando se encontrou esperma na vagina das fêmeas. Sete dias após as fêmeas parirem, elas foram sacrificadas e as análises foram feitas. O grupo que recebeu maior concentração de extrato de soja na ração teve abertura vaginal e ovulação antes que o grupo controle. Este último apresentou ciclos mais longos, comprovando atividade estrogênica da ração enriquecida com extrato de soja (GALLO et al., 1999).

Outro estudo realizado em animais, usando, porém 25 macacas em pré-menopausa, investigou-se os efeitos de dieta rica em soja, recebendo dose diária aproximada 129 $\mathrm{mg} /$ dia de isoflavona. Um grupo de 25 macacas (placebo) recebeu caseína na mesma proporção. Avaliando-se o V.M. de Hustin [V.M. = (0,2x\% células parabasais) $+(0,6 \times \%$ células intermediárias $)=(\%$ de células superficiais $)$ ] entre os dois grupos, não se encontrou diferenças estatisticamente significativas (WOOD et al., 2006).

Vários estudos estão sendo conduzidos, em animais e mulheres na pós-menopausa, com o objetivo de caracterizar de forma clara os efeitos da isoflavona, um fitoestrógeno, nesta população. E evidente que a isoflavona proporciona várias melhoras na pósmenopausa, mas os estudos existentes ainda deixam dúvida sobre seus reais benefícios, as doses recomendadas e as possíveis contra-indicações. Essa caracterização é fundamental, pois fornecerá dados mais claros sobre os efeitos dos fitoestrógenos, no entanto, é difícil a condução de um estudo no qual a dose diária de isoflavona seja bem determinada, uma vez que vários alimentos presentes nas dietas convencionais apresentam essas substâncias e, também, porque várias das alterações que ocorrem durante a menopausa são subjetivas, dependendo do relato da percepção da paciente, como ondas de calor, ansiedade, fadiga mental e outros. 


\section{OBJETIVO}

O objetivo do presente estudo foi avaliar os efeitos das isoflavonas e do placebo caseína, em mulheres menopausadas, investigando os seguintes parâmetros:

1) Maturação epitelial: usando o Índice de Maturação (I.M.), Índice de Picnose (I.P.), índice de Eosinofilia (I.E.) e o Valor de Maturação (M.V.). Estes parâmetros foram avaliados nos esfregaços vaginais e no sedimento urinário (urocitograma).

2) Microbiota vaginal: determinação da presença de agentes microbiológicos em exame direto a fresco e esfregaços corados pela técnica de Gram.

3) Exame colpocitológico: análise das lâminas do esfregaço vaginal, contendo células do ectocérvice, endocérvice e parede vaginal, coradas pela técnica de Shorr, avaliando alterações sugestivas de malignidade, pré-malignidade inflamatórias ou infecciosas causadas por agentes patogênicos.

4) Determinação do índice de Kuppermann - através de um questionário padrão contendo 28 itens para avaliar os sintomas da menopausa.

Para atender aos objetivos acima foi proposto um estudo duplo cego randomizado, constituído por um grupo de mulheres tratadas com $40 \mathrm{mg} /$ dia de isoflavona e um grupo controle,recebendo caseína (placebo) na mesma concentração diária, por um período de 24 semanas. 


\section{CASUISTICA E MÉTODOS}

\subsection{Protocolo Clínico}

As voluntárias do presente estudo foram mulheres em pós-menopausa, que procuraram o ambulatório de climatério do Centro de Saúde Escola Cuiabá da Faculdade de Medicina da USP (CSE-FMRP-USP). Essas mulheres foram informadas, por escrito e verbalmente pela pesquisadora e médico ginecologista, sobre os objetivos e os possíveis riscos deste estudo. O ANEXO I apresenta o parecer do Comitê de Ética em Pesquisa do CSE-Cuiabá, onde ocorreu a seleção das pacientes. As voluntárias foram informadas sobre o direito de interromperem o estudo a qualquer momento, sem sofrerem danos ou represálias. Cada voluntária deu o seu consentimento por escrito (ANEXOII).

As pacientes selecionadas obedeceram aos seguintes critérios:

1. De inclusão: mamografia, exames ginecológicos recentes e normais; cessação da menstruação por mais de um ano; possuir pelo menos um dos ovários; índice de massa corporal (IMC) menor que 30; FSH maior que $40 \mathrm{UI} / \mathrm{L}$.

2. De exclusão: doença gastrintestinal, cardíaca ou osteoporose; fumante; vegetarianas; uso contínuo de medicamentos; tratamento hormonal durante os últimos 12 meses; suspeita de abuso de álcool ou uso de drogas; câncer em si ou em seus familiares.

Antes da coleta foi aplicado um questionário às pacientes voluntárias, conforme preconizado pelo Ministério da Saúde, constando de questões sobre a caracterização física das pacientes, sintomas gerais da menopausa, informações sobre reposição estroprogestiva anterior, medicamentos em uso, vida sexual, paridade, contracepção, procedimentos cirúrgicos ginecológicos e resultados de alterações de exames anteriores (ANEXO III). 


\subsection{Tratamentos}

As mulheres do Grupo Controle que constituíram o grupo placebo usaram diariamente, por via oral, cápsulas contendo 40 mg de caseína, tomada em dose única no mesmo horário do dia, por 24 semanas. As mulheres do Grupo Tratado usaram diariamente, por via oral, cápsulas de $40 \mathrm{mg}$ de isoflavona, tomada em dose única no mesmo horário do dia, por 24 semanas.

As voluntárias deste estudo, bem como o clínico responsável pela seleção das mesmas, não souberam da composição das cápsulas prescritas e consumidas, por tratar-se de um estudo randomizado duplo cego placebo controlado. As pacientes receberam gratuitamente tratamento por 24 semanas consecutivas.

\subsection{Exames constantes no prontuário médico}

A consulta ao prontuário médico das voluntárias forneceu resultados de exames que fazem parte da rotina de acompanhamento destas pacientes, dentro do Centro de Saúde Escola Cuiabá, tais como peso e altura, pressão sistólica, pressão diastólica e anos de menopausa.

Durante a consulta ginecológica, a paciente junto com a pós-graduanda preencheram a requisição da colpocitologia (ANEXO IV), onde consta a identificação da paciente (idade, data de nascimento, cor, estado civil, gestações, partos, abortos, data do ínicio da menopausa), motivo da consulta (adesão ao estudo), exames anteriores, exame ginecológico e impressão diagnostica, data de coleta, assinatura do médico requisitante.

Após a consulta e coleta do material para exames, as pacientes eram orientadas sobre a dispensação das cápsulas contendo isoflavona ou caseína. A entrega das cápsulas foi mensalmente sempre precedida por um questionário sobre as queixas clínicas (ANEXO V) O questionário era respondido mensalmente durante todo o tratamento, pois estes dados foram utilizados para construir o índice de Kupperman. 


\subsection{Colheitas citológicas}

Foram colhidas lâminas citológicas durante consulta, para

a) Exame Colpocitológico ou Citologia tríplice:

1. Células da parede vaginal (terço médio posterior), contendo células do epitélio escamoso pluriestratificado não ceratinizado onde foram estudadas as células para o cálculo da maturação celular;

2. Células do ectocérvice, contendo células intermediárias, superficiais e para basais para identificação da microbiota normal e patogênica e exame preventivo de câncer de colo do útero;

3. Células da endocérvice, do epitélio glandular para identificação da microbiota normal e patogênica e exame preventivo de câncer uterino.

Esta coleta foi feita em duplicata, sendo uma das lâminas processada conforme rotina do Posto de Saúde. A segunda lâmina foi fixada em álcool 85\%, corada pelo método de Shorr modificado e analisada no laboratório de Citologia Clínica da FCFRP/USP para obtenção dos resultados aqui apresentados.

b) Exame bacterioscópico: células da parede vaginal. Estas lâminas foram secas ao ar e posteriormente coradas pelo método de Gram.

c) Exame direto a fresco: células vaginais coletadas com swab e escova cervical, usada para coleta endocervical. Este material foi acondicionado em tubo de Falcon com tampa, contendo $0,5 \mathrm{ml}$ de soro fisiológico e foi analisado sem coloração, entre lâmina e lamínula.

As células vaginais coletas para o exame direto a fresco mantidas em soro fisiológico, como apresentado anteriormente foram submetidas ao seguinte procedimento:

a) Centrifugação do material restante do exame direto a fresco, por 10 minutos a 1000 rpm;

b) Sedimento do exame direto a fresco lavado com $10 \mathrm{ml}$ de solução de Ringer 
1:1 em solução salina com centrifugação a 1000 rpm por 10 minutos;

c) O sedimento do exame direto a fresco foi depositado em lâmina contendo uma camada de albumina de Mayer (obtida como descrito anteriomente), fixada em álcool 85\% e corada pelo método de Shorr modificado.

Nas células vaginais coletadas com swab e escova cervical para exame direto a fresco foi contado o número de leucócitos/hemácias, determinando o índice de maturação, presença de leveduras, bem como pesquisa para tricomoníase.

\subsection{Urina para o urocitograma}

As amostras de urina das pacientes deste estudo foram coletadas pela manhã, sendo a primeira urina do dia. Este material foi submetido a:

a) Centrifugação de $15 \mathrm{ml}$ de urina (em tubos de Falcon) a $1000 \mathrm{rpm}$ por 10 minutos;

b) Sedimento urinário lavado com $10 \mathrm{ml}$ de solução de Ringer 1:1 em solução salina com centrifugação a 1000 rpm por 10 minutos, por duas vezes;

c) O sedimento urinário foi depositado em lâmina contendo uma camada de albumina de Mayer, fixada em álcool 85\% e corada pelo método de Shorr modificado. A albumina de Mayer foi obtida pela mistura de partes iguais de glicerina e clara de ovos de galinha ( $v / v)$ e, finalmente, pelo acréscimo de cristal de timol. Em seguida passou-se uma fina camada da mistura citada em cada lâmina, constituindo assim um pre-coated. A lâmina tratada foi dessecada em estufa a $37^{\circ} \mathrm{C}$, por 24 horas (BEZERRA et al., 2003).

\subsection{Coloração}

\subsubsection{Coloração das lâminas para colpocitologia, pelo método de Shorr, modificado por BIBBO, 1991:}

Fixação em álcool 85\%

1. Lavagem das lâminas em água corrente presas em espiral metálica por 03 minutos. 
2. Corante hematoxolina - 2 a 3 minutos.

3. Lavagem em água corrente até total desprendimento do corante.

4. Corante segundo Shorr - 04 minutos.

5. Desidratação por passagens de dois minutos cada por:
a) álcool 95\%
b) álcool 95\%
c) álcool 95\%
d) álcool absoluto
e) álcool absoluto

6. Diafanização por passagens sucessivas de dois minutos cada por :
a) xilol/álcool
b) xilol
c) xilol

7. Montagem em Entellan.

As lâminas assim coradas foram examinadas em todos os seus campos. É onde se pesquisam as células malignas e pré malignas, segundo Bethesda, os agentes microbiológicos que podem estar presentes e os aspectos celulares inflamatórios.

\subsubsection{Coloração das lâminas de bacterioscopia pela técnica de Gram modificada:}

A lâmina de bacterioscopia após colheita foi flambada ao fogo (03 passadas rápidas com esfregaço do lado oposto ao fogo) e deixadas de volta no suporte para esfriar. Em seguida coradas.

1. Violeta de genciana - 10 gotas

2. 10 gotas de bicarbonato de sódio a 1\% depositado sobre a lâmina e desprezado após dois minutos.

3. Solução de lugol de Gram diluído 1:10, em água destilada, depositado 2 minutos sobre a lâmina, depois desprezar o liquido sobrenadante. 
4. Lavagem com álcool/acetona $50 \%$ até que o líquido resultante não apresente coloração.

5. Enxágüe em água

6. Safranina 1\% - 10 gotas - 1 minuto, desprezar liquido sobrenadante, lavar em água corrente.

Examinadas com lente de imersão após secagem. 


\section{RESULTADOS}

O presente estudo, com duração de 24 semanas, contou com a participação de 49 mulheres, 23 tratadas com $40 \mathrm{mg} / \mathrm{dia}$ de placebo (caseína), constituindo o grupo controle, e 26 mulheres medicadas com $40 \mathrm{mg} / \mathrm{dia}$ de isoflavona. Três mulheres do grupo controle descontinuaram o tratamento, uma por doença adquirida no transcorrer da pesquisa (pneumonia), sendo necessária a antibioticoterapia, e duas tiveram seu valor de FSH menor que 30, estando em desacordo com os critérios de inclusão, estabelecidos neste estudo.

Os dois grupos apresentaram-se homogêneos no, início do estudo, em relação as características físicas (FIGURA 11A), concentração plasmática de $\mathrm{FSH}$, estradiol e lipídeos (FIGURA 11B). Além disso, as mulheres se constituíram em grupos homogêneos no que se refere à idade da menarca, da sexarca, do número de parceiros e do número de anos desde o início da menopausa. Observou-se diferença significativa na paridade, maior no grupo placebo $(P=0,0005)$ (TABELA I e FIGURA 11C). 
TABELA I - Características das voluntárias.

\begin{tabular}{|c|c|c|c|}
\hline PARÂMETROS & $\begin{array}{l}\text { PLACEBO } \\
(n=23)\end{array}$ & $\begin{array}{l}\text { ISOFLAVONA } \\
(n=26)\end{array}$ & $\mathbf{P}$ \\
\hline Idade (anos) & $55,6 \pm 5,7$ & $55,4 \pm 4,6$ & 0,8 \\
\hline Altura (m) & $1,6 \pm 0,1$ & $1,6 \pm 0,1$ & 0,7 \\
\hline Peso (Kg) & $67,3 \pm 8,0$ & $63,7 \pm 10,5$ & 0,3 \\
\hline IMC $\left(\mathrm{Kg} / \mathrm{m}^{2}\right)$ & $27,3 \pm 3,1$ & $25,8 \pm 3,6$ & 0,1 \\
\hline Pressão Sistólica (mmHg) & $127,6 \pm 15,7$ & $125,0 \pm 14,0$ & 0,6 \\
\hline Pressão Diastólica (mmHg) & $81,1 \pm 8,5$ & $81,7 \pm 9,2$ & 0,9 \\
\hline $\mathrm{FSH}$ & $76,9 \pm 27,9$ & $82,6 \pm 29,7$ & 0,5 \\
\hline Estradiol & $25,1 \pm 3,1$ & $18,7 \pm 12,3$ & 0,1 \\
\hline Colesterol total & $223,3 \pm 57,3$ & $205,3 \pm 34,1$ & 0,1 \\
\hline HDL & $49,6 \pm 8,9$ & $50,5 \pm 11,2$ & 0,4 \\
\hline LDL & $148,7 \pm 52,7$ & $132,0 \pm 30,6$ & 0,1 \\
\hline VLDL & $25,4 \pm 13,0$ & $22,8 \pm 9,7$ & 0,4 \\
\hline Triglicerídeos & $224,7 \pm 65,3$ & $114,3 \pm 49,1$ & 0,5 \\
\hline Idade da Menarca & $13,5 \pm 1,8$ & $13,4 \pm 1,6$ & 0,8 \\
\hline Idade da Sexarca & $20,7 \pm 3,3$ & $21,7 \pm 6,7$ & 0,6 \\
\hline Número de parceiros & $1,5 \pm 1,0$ & $1,6 \pm 1,5$ & 0,7 \\
\hline Paridade & $3,9 \pm 2,2$ & $2,2 \pm 1,7$ & 0,0005 * \\
\hline Anos desde a menopausa & $7,9 \pm 5,6$ & $7,6 \pm 6,2$ & 0,8 \\
\hline
\end{tabular}

Os dados são apresentados como Média \pm Desvio Padrão e o valor de $\mathrm{P}$ foi obtido pelo Teste $t$ de Student pareado.

${ }^{*} P \leq 0.05$, comparando antes e após os tratamentos dentro de cada grupo. 

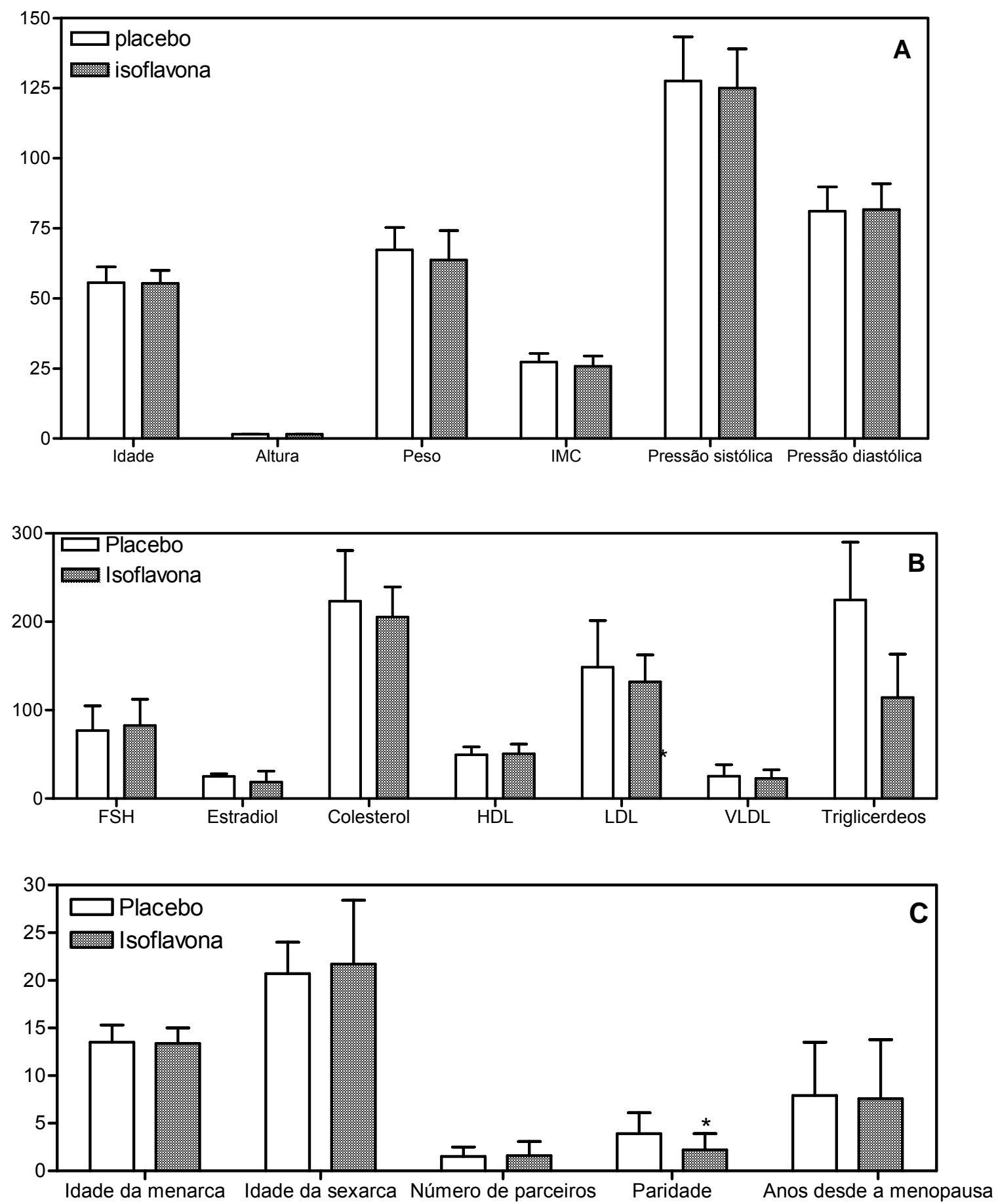

FIGURA 11 - Característica das voluntárias. (A) Características físicas das pacientes; (B) Concentração plasmática de FSH, estradiol e lipídeos; (C) Idade de menarca, sexarca, número de parceiros, paridade e anos desde a menopausa.

Os dados são apresentados como Média \pm Desvio Padrão e o valor de $P$ foi obtido pelo Teste $t$ de Student pareado.

${ }^{*} P \leq 0.05$, comparando antes e após os tratamentos dentro de cada grupo. 


\subsection{Maturação do epitélio vaginal}

\subsubsection{Colpocitograma - Índice de maturação}

Após as 24 semanas de tratamento com isoflavona, observou-se, no colpocitograma, diminuição significativa na porcentagem de células parabasais $(P=0,003)$, aumento, também significativo, das células superficiais cianofílicas $(P=0,006)$ e aumento, não significativo, da porcentagem das células intermediárias e das superficiais eosinofílicas ( $P=0,054$ e 0,18 , respectivamente). No entanto, nenhuma variação significativa foi observada na porcentagem destas células nas mulheres que receberam placebo (TABELA II e FIGURA 12)

TABELA II - Tipos celulares do I.M. com dados extraídos do colpocitograma das mulheres antes e após o tratamento com $40 \mathrm{mg} /$ dia de isoflavona e $40 \mathrm{mg} /$ dia de caseína, durante 24 semanas.

\begin{tabular}{|c|c|c|c|c|c|c|}
\hline TIPO DE & \multicolumn{3}{|c|}{ PLACEBO } & \multicolumn{3}{c|}{ ISOFLAVONA } \\
\cline { 2 - 7 } & Antes (\%) & Depois (\%) & P & Antes (\%) & Depois (\%) & P \\
\hline Parabasais & $29,9 \pm 33,9$ & $32,9 \pm 35,1$ & 0,094 & $25,6 \pm 22,5$ & $10,9 \pm 18,5$ & $0,003^{*}$ \\
\hline Intermediárias & $66,7 \pm 31,0$ & $61,7 \pm 31,6$ & 0,216 & $65,2 \pm 29,6$ & $75,1 \pm 16,8$ & 0,054 \\
\hline $\begin{array}{c}\text { Superficiais } \\
\text { Cianofilicas }\end{array}$ & $4,2 \pm 5,7$ & $4,3 \pm 4,1$ & 0,931 & $6,4 \pm 10,7$ & $10,0 \pm 7,6$ & $0,006^{*}$ \\
\hline $\begin{array}{c}\text { Superficiais } \\
\text { Eosinofilicas }\end{array}$ & $0,9 \pm 2,2$ & $1,0 \pm 2,4$ & 0,672 & $2,7 \pm 7,7$ & $4,0 \pm 5,7$ & 0,180 \\
\hline
\end{tabular}

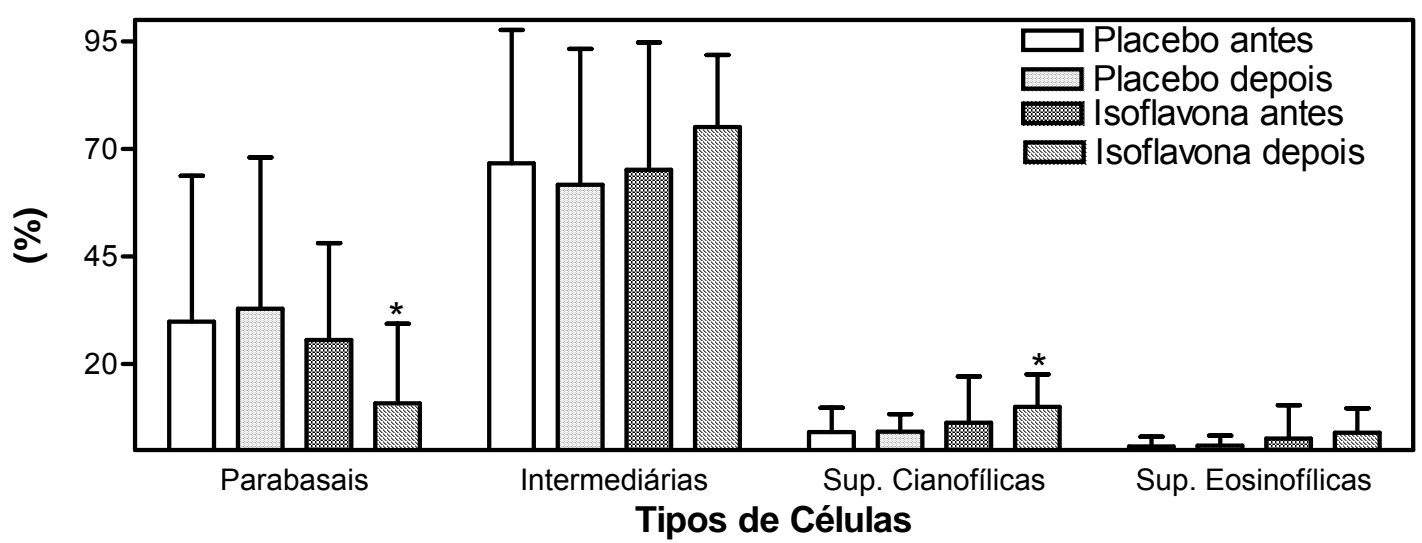

FIGURA 12 - Representação gráfica dos tipos celulares do I.M extraídos do colpocitograma de mulheres antes e após o tratamento com $40 \mathrm{mg} / \mathrm{dia}$ de isoflavona e $40 \mathrm{mg} / \mathrm{dia}$ de caseína, durante 24 semanas .

Os dados são apresentados como Média \pm Desvio Padrão e o valor de $\mathrm{P}$ foi obtido pelo Teste $t$ de Student pareado.

* $P \leq 0.05$, comparando antes e após os tratamentos dentro de cada grupo. 


\subsubsection{Colpocitograma - Índice de Picnose, Índice de Eosinofilia e Valor de Maturação}

Após as 24 semanas de tratamento com isoflavona, observou-se, no colpocitograma, aumento significativo no V.M. ( $P=0,007)$, nas mulheres tratadas com isoflavona. Nenhuma variação significativa foi observada nos I.P., I.E. e nem nos resultados das mulheres que receberam placebo (TABELA III e FIGURA 13).

TABELA III - Avaliação do I.P., I.E. e V.M. com dados extraídos do colpocitograma das mulheres antes e após o tratamento com $40 \mathrm{mg} / \mathrm{dia}$ de isoflavona e $40 \mathrm{mg} /$ dia de caseína, durante 24 semanas.

\begin{tabular}{|c|c|c|c|c|c|c|}
\hline \multirow{2}{*}{ ÍNDICES } & \multicolumn{3}{|c|}{ PLACEBO } & \multicolumn{3}{c|}{ ISOFLAVONA } \\
\cline { 2 - 7 } & Antes (\%) & Depois (\%) & P & Antes (\%) & Depois (\%) & P \\
\hline I.P. & $5,3 \pm 7,8$ & $5,3 \pm 5,8$ & 0,970 & $9,2 \pm 18,2$ & $14,1 \pm 11,8$ & 0,080 \\
\hline I.E. & $0,9 \pm 2,2$ & $1,0 \pm 2,4$ & 0,670 & $2,8 \pm 7,7$ & $4,0 \pm 5,7$ & 0,180 \\
\hline V.M. & $37,4 \pm 18,8$ & $36,2 \pm 18,5$ & 0,360 & $41,8 \pm 19,4$ & $50,5 \pm 13,7$ & $0,007^{*}$ \\
\hline
\end{tabular}

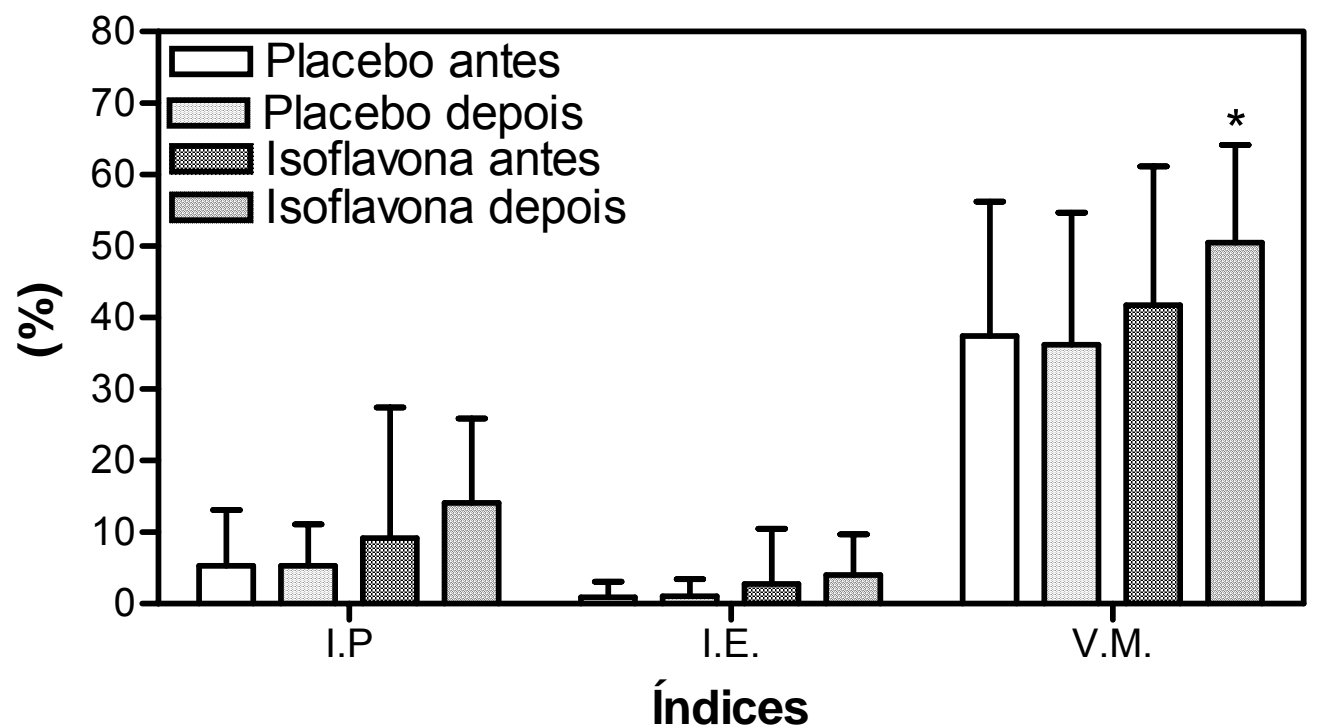

FIGURA 13 - Representação gráfica dos I.P., I.E. e Valor de V.M. extraídos do colpocitograma das mulheres antes e após o tratamento com $40 \mathrm{mg} / \mathrm{dia}$ de isoflavona e $40 \mathrm{mg} / \mathrm{dia}$ de caseína, durante 24 semanas.

Os dados são apresentados como Média \pm Desvio Padrão e o valor de $\mathrm{P}$ foi obtido pelo Teste $t$ de Student pareado.

* $P \leq 0.05$, comparando antes e após os tratamentos dentro de cada grupo. 


\subsubsection{Colpocitograma - Coleta úmida}

No colpocitograma (coleta úmida) houve diminuição significativa na porcentagem de células parabasais $(P=0,04)$ e aumento também significativo das células superficiais cianofílicas $(P=0,008)$. Houve aumento, não significativo, da porcentagem das células intermediárias e, diminuição não significativas, das células superficiais eosinofílicas nas pacientes tratadas com isoflavona. No entanto, nenhuma variação significativa foi observada na porcentagem nas células intermediárias das mulheres tratadas com isoflavona. Nas pacientes que receberam placebo não se observou nenhuma alteração significativa nestes parâmetros celulares no colpocitograma de células de coleta úmida (TABELA IV e FIGURA 14).

TABELA IV - Tipos celulares do I.M. com dados extraídos do colpocitograma obtido da secreção vaginal para exame direto a fresco (coleta úmida) das mulheres antes e após o tratamento com 40 $\mathrm{mg} / \mathrm{dia}$ de isoflavona e $40 \mathrm{mg} / \mathrm{dia}$ de caseína, durante 24 semanas.

\begin{tabular}{|c|c||c|c|c||c||c|}
\hline $\begin{array}{c}\text { TIPOS DE } \\
\text { CÉLULAS }\end{array}$ & \multicolumn{2}{|c|}{ PLACEBO } & \multicolumn{2}{c|}{ ISOFLAVONA } \\
\hline Parabasais & $29,9 \pm 33,3$ & $32,9 \pm 35,1$ & 0,09 & $26,0 \pm 28,9$ & $16,4 \pm 21,5$ & $0,04^{*}$ \\
\hline Intermediárias & $66,70 \pm 31,7$ & $62,7 \pm 34,2$ & 0,22 & $70,5 \pm 27,3$ & $76,9 \pm 19,4$ & 0,20 \\
\hline $\begin{array}{c}\text { Superficiais } \\
\text { Cianofílicas }\end{array}$ & $3,40 \pm 4,7$ & $4,6 \pm 14,8$ & 0,75 & $3,3 \pm 5,3$ & $6,7 \pm 8,6$ & 0,008 * \\
\hline $\begin{array}{c}\text { Superficiais } \\
\text { Eosinofílicas }\end{array}$ & $0,04 \pm 0,20$ & $0,00 \pm 0,00$ & 0,33 & $0,15 \pm 0,46$ & $0,04 \pm 0,20$ & 0,18 \\
\hline
\end{tabular}

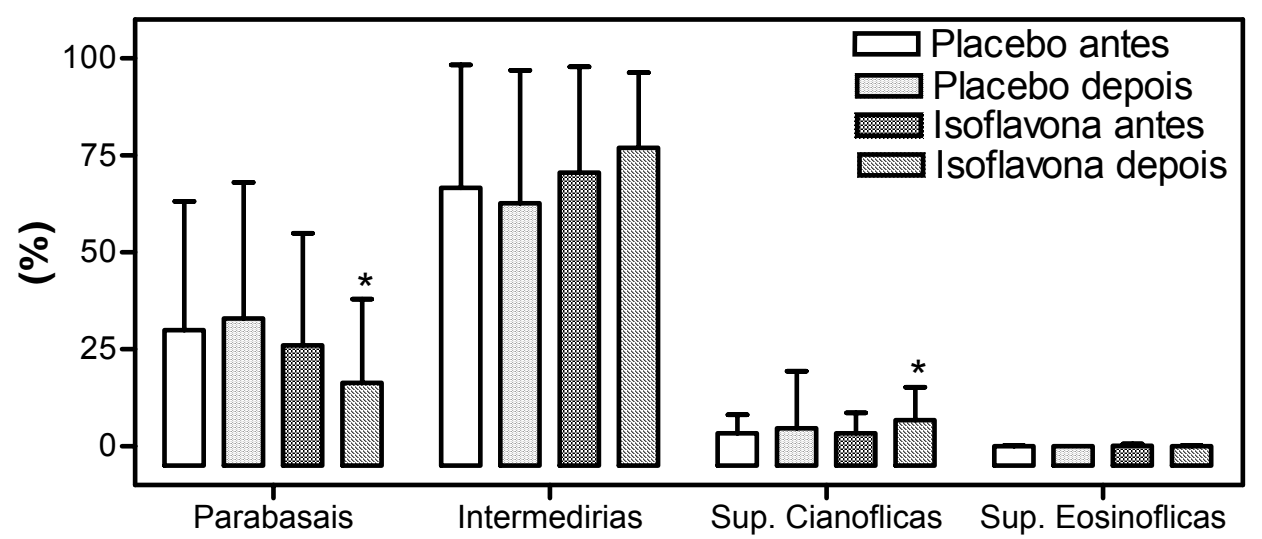

Tipos de células

FIGURA 14 - Representação gráfica dos tipos celulares do I.M extraídos do colpocitograma obtido da secreção vaginal para exame direto a fresco (coleta úmida) das mulheres antes e após o tratamento com $40 \mathrm{mg} / \mathrm{dia}$ de isoflavona e $40 \mathrm{mg} /$ dia de caseína, durante 24 semanas.

Os dados são apresentados como Média \pm Desvio Padrão e o valor de $\mathrm{P}$ foi obtido pelo Teste $t$ de Student pareado.

${ }^{*} \mathrm{P} \leq 0.05$, comparando antes e após os tratamentos dentro de cada grupo. 


\subsubsection{Colpocitograma - Coleta úmida - Índice de picnose, índice de eosinofilia e valor de maturação}

Após as 24 semanas de tratamento com isoflavona, observou-se, no colpocitograma (coleta úmida) aumento significativo no I.P. $(P=0,01)$ e no V.M. $(P=0,004)$, nenhuma variação significativa foi observada no I.E. ou nos resultados de mullheres que receberam placebo (TABELA $V$ e FIGURA 15).

TABELA V - Avaliação do I.P., I.E. e V.M. com dados extraídos do colpocitograma obtido da secreção vaginal para exame direto a fresco (coleta úmida) das mulheres antes e após o tratamento com 40 $\mathrm{mg} / \mathrm{dia}$ de isoflavona e $40 \mathrm{mg} / \mathrm{dia}$ de caseína, durante 24 semanas.

\begin{tabular}{|c|c||c||c|c||c||c|}
\hline \multirow{2}{*}{ ÍNDICES } & \multicolumn{3}{|c|}{ PLACEBO } & \multicolumn{2}{c|}{ ISOFLAVONA } \\
\cline { 2 - 7 } & Antes (\%) & Depois (\%) & P & Antes (\%) & Depois (\%) & P \\
\hline I.P. & $3,4 \pm 4,8$ & $4,5 \pm 14,5$ & 0,75 & $3,4 \pm 5,5$ & $6,8 \pm 6,7$ & 0,01 * \\
\hline I.E. & $0,04 \pm 0,21$ & $0,00 \pm 0,00$ & 0,33 & $0,15 \pm 0,46$ & $0,04 \pm 0,20$ & 0,18 \\
\hline V.M. & $36,7 \pm 18,3$ & $35,8 \pm 20,7$ & 0,65 & $38,7 \pm 15,7$ & $45,6 \pm 13,0$ & 0,004 * \\
\hline
\end{tabular}

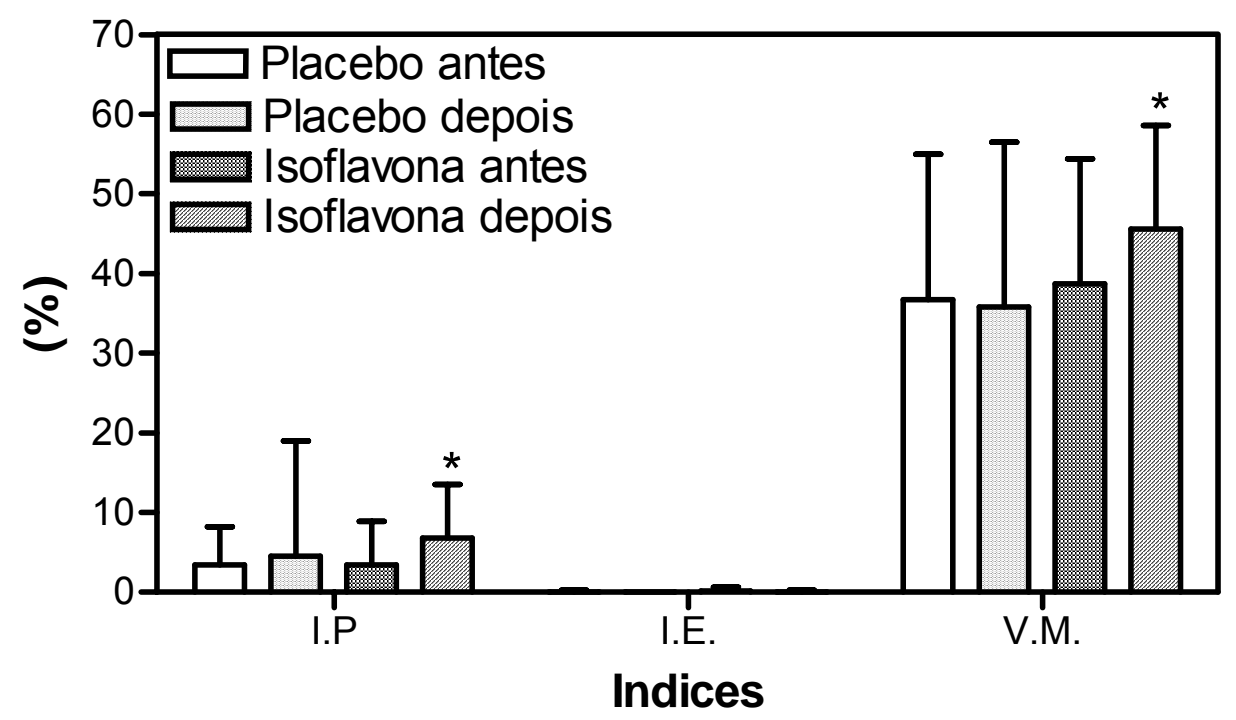

FIGURA 15 - Representação gráfica do I.P., I.E. e V.M. extraídos do colpocitograma obtido por coleta úmida das mulheres antes e após o tratamento com $40 \mathrm{mg} /$ dia de isoflavona e $40 \mathrm{mg} / \mathrm{dia}$ de caseína, durante 24 semanas.

Os dados são apresentados como Média \pm Desvio Padrão e o valor de $\mathrm{P}$ foi obtido pelo Teste $t$ de Student pareado.

${ }^{*} P \leq 0.05$, comparando antes e após os tratamentos dentro de cada grupo. 


\subsubsection{Urocitograma}

A citologia hormonal, através do urocitograma, foi realizada e os resultados obtidos foram semelhantes aos resultados do colpocitograma, com diminuição significativa na porcentagem de células parabasais $(P=0,008)$, aumento significativo das células superficiais cianofílicas $(P=0,013)$ e das células superficiais eosinofílicas $(P=0,002)$. Por outro lado, observou-se aumento, não significativo, na porcentagem das células intermediárias e nenhuma variação foi observada na porcentagem de todas estas células nas mulheres que receberam placebo (TABELA VI e FIGURA 16).

TABELA VI - Tipos celulares do I.M. com dados extraídos do urocitograma das mulheres antes e após o tratamento com $40 \mathrm{mg} /$ dia de isoflavona e $40 \mathrm{mg} /$ dia de caseína, durante 24 semanas.

\begin{tabular}{|c|l||l||l|l||l||l|}
\hline $\begin{array}{c}\text { TIPOS DE } \\
\text { CÉLULAS }\end{array}$ & Antes (\%) & Depois (\%) & P & Antes (\%) & Depois (\%) & P \\
\hline Parabasais & $22,0 \pm 19,4$ & $24,1 \pm 21,2$ & 0,133 & $21,1 \pm 20,0$ & $10,3 \pm 14,4$ & $0,008^{*}$ \\
\hline Intermediárias & $71,7 \pm 19,4$ & $71,5 \pm 19,6$ & 0,857 & $71,5 \pm 17,8$ & $71,0 \pm 22,5$ & 0,928 \\
\hline $\begin{array}{c}\text { Superficiais } \\
\text { Cianofílicas }\end{array}$ & $6,2 \pm 6,5$ & $4,7 \pm 5,5$ & 0,036 & $6,2 \pm 8,8$ & $12,1 \pm 14,1$ & $0.013^{*}$ \\
\hline $\begin{array}{c}\text { Superficiais } \\
\text { Eosinofílicas }\end{array}$ & $1,2 \pm 2,7$ & $6,4 \pm 0,94$ & 0,147 & $1,5 \pm 3,2$ & $2,6 \pm 3,8$ & $0.002^{*}$ \\
\hline
\end{tabular}

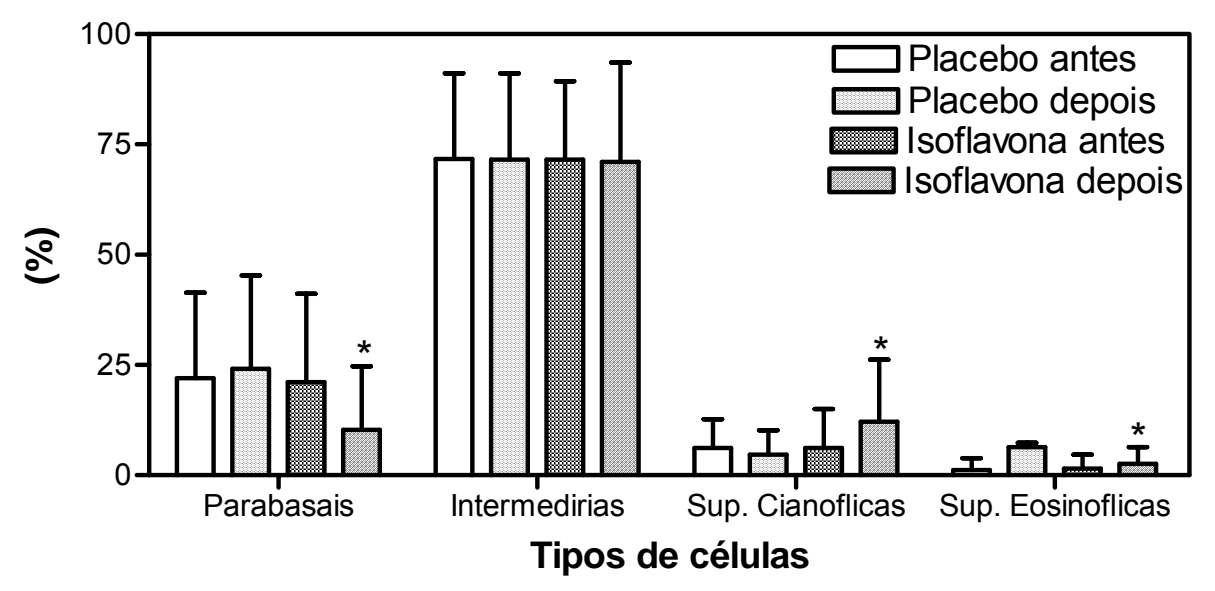

FIGURA 16 - Representação gráfica dos tipos celulares do I.M extraídos do Urocitograma das mulheres antes e após o tratamento com $40 \mathrm{mg} /$ dia de isoflavona e $40 \mathrm{mg} / \mathrm{dia}$ de caseína, durante 24 semanas.

Os dados são apresentados como Média \pm Desvio Padrão e o valor de $\mathrm{P}$ foi obtido pelo Teste $t$ de Student pareado.

${ }^{*} P \leq 0.05$, comparando antes e após os tratamentos dentro de cada grupo. 


\subsubsection{Urocitograma - Índice de Picnose, Índice de Eosinofilia e Valor de Maturação}

Após as 24 semanas de tratamento com isoflavona, observou-se, no urocitograma, aumento significativo no I.P. $(P=0,006)$, do I.E. $(P=0,002)$ e no V.M. $(P=0,0008)$, No grupo placebo observou-se uma diminuição significativa no I.P. $(P=0,02)$ e no V.M. $(P=0,002)$ (TABELA VII e FIGURA 17).

TABELA VII - Avaliação do I.P., I.E. e do V.M. com dados extraídos do urocitograma das mulheres antes e após o tratamento com $40 \mathrm{mg} /$ dia de isoflavona e $40 \mathrm{mg} /$ dia de caseína, durante 24 semanas.

\begin{tabular}{|c|c|c||c|c|c||c|}
\hline \multirow{2}{*}{ ÍNDICES } & \multicolumn{3}{|c|}{ PLACEBO } & \multicolumn{3}{c|}{ ISOFLAVONA } \\
\cline { 2 - 7 } & Antes (\%) & Depois (\%) & P & Antes (\%) & Depois (\%) & P \\
\hline I.P. & $7,4 \pm 8,4$ & $5,2 \pm 5,7$ & $0,02^{*}$ & $7,7 \pm 10,5$ & $14,8 \pm 17,2$ & $0,006^{*}$ \\
\hline I.E. & $1,2 \pm 2,7$ & $0,4 \pm 0,9$ & 0,12 & $1,5 \pm 3,2$ & $2,7 \pm 3,8$ & $0,002^{*}$ \\
\hline V.M. & $43,2 \pm 12,9$ & $39,8 \pm 11,5$ & $0,02^{*}$ & $43,3 \pm 14,1$ & $52,3 \pm 13,1$ & $0,0008^{*}$ \\
\hline
\end{tabular}

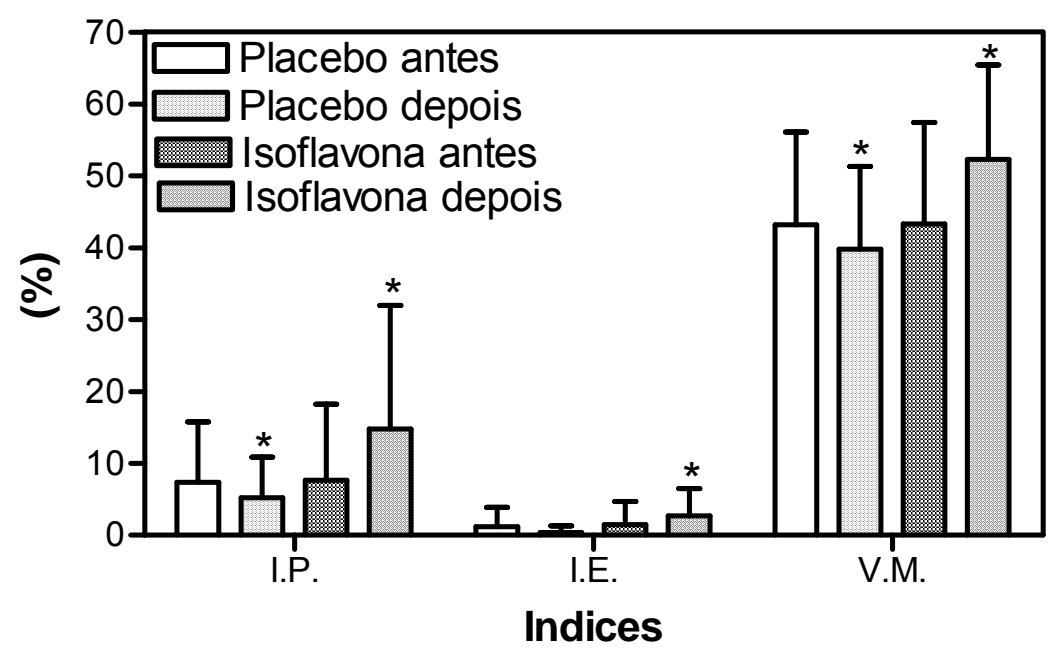

FIGURA 17 - Representação gráfica do I.P., I.E. e V.M. extraídos do extraídos do urocitograma das mulheres antes e após o tratamento com $40 \mathrm{mg} /$ dia de isoflavona e $40 \mathrm{mg} / \mathrm{dia}$ de caseína, durante 24 semanas.

Os dados são apresentados como Média \pm Desvio Padrão e o valor de $\mathrm{P}$ foi obtido pelo Teste $t$ de Student pareado.

${ }^{*} P \leq 0.05$, comparando antes e após os tratamentos dentro de cada grupo. 


\subsection{Microbiota Vaginal}

A porcentagem de células epiteliais, leucócitos e morfotipos bacterianos: Bacilos de Döederlein, outros bacilos Gram positivos, bacilos Gram negativos, cocos e cocobacilos, em lâminas colhidas durante as consultas ginecológicas, de mulheres antes e após 24 semanas de tratamento com $40 \mathrm{mg} / \mathrm{dia}$ de isoflavona e $40 \mathrm{mg} / \mathrm{dia}$ de caseína, coradas pelo Gram estão apresentado na Tabela VIII. Foi significativa a diminuição de células epiteliais $(P=0,005)$ e o aumento dos Bacilos de Döederlein $(P=0,005)$, não tendo sido significativa a variação na porcentagem dos leucócitos, nas mulheres tratadas com isoflavona. Não houveram alterações significativas na porcentagem das células das mulheres que receberam placebo (FIGURA 18).

TABELA VIII - Bacterioscopia da secreção vaginal das mulheres antes e após o tratamento com 40 $\mathrm{mg} / \mathrm{dia}$ de isoflavona e $40 \mathrm{mg} / \mathrm{dia}$ de caseína, durante 24 semanas.

\begin{tabular}{|c|c|c|c|c|c|c|}
\hline \multirow[b]{2}{*}{$\begin{array}{l}\text { TIPOS DE } \\
\text { CÉLULAS }\end{array}$} & \multicolumn{3}{|c|}{ PLACEBO } & \multicolumn{3}{|c|}{ ISOFLAVONA } \\
\hline & Antes (\%) & Depois (\%) & $\mathbf{P}$ & Antes (\%) & Depois (\%) & $\mathbf{P}$ \\
\hline Epiteliais & $17,8 \pm 18,9$ & $18,7 \pm 16,8$ & 0,799 & $16,2 \pm 22,0$ & $9,4 \pm 11,0$ & $0,005^{*}$ \\
\hline Leucócitos & $9,1 \pm 11,7$ & $8,6 \pm 10,7$ & 0,861 & $10,8 \pm 8,5$ & $18,7 \pm 16,8$ & 0,699 \\
\hline $\begin{array}{l}\text { Bacilos } \\
\text { Döederlein }\end{array}$ & $45,3 \pm 29,2$ & $42,3 \pm 29,0$ & 0,683 & $30,5 \pm 30,5$ & $52,2 \pm 33,6$ & $0.005^{*}$ \\
\hline
\end{tabular}

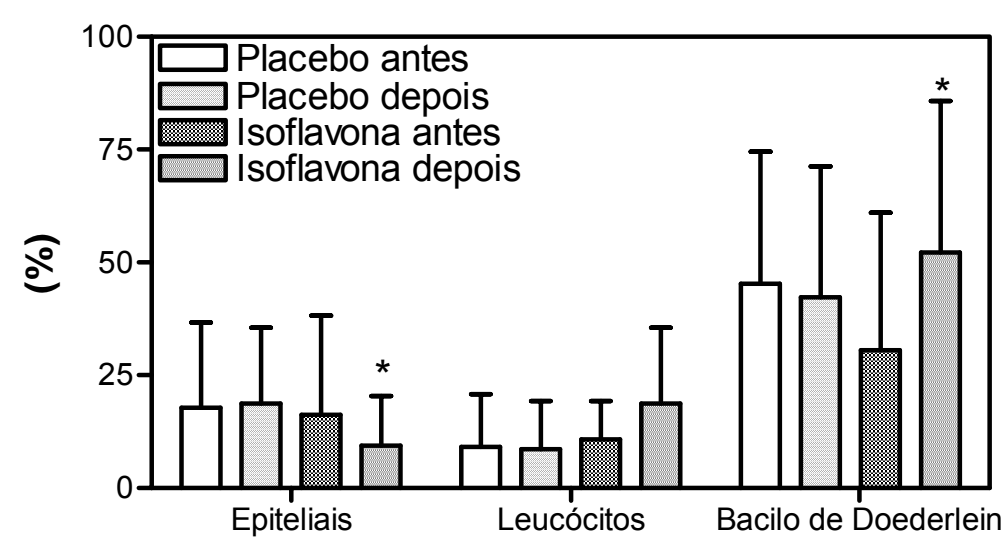

Tipos de células

FIGURA 18 - Representação gráfica da bacterioscopia da secreção vaginal das mulheres antes e após o tratamento com $40 \mathrm{mg} / \mathrm{dia}$ de isoflavona e $40 \mathrm{mg} /$ dia de caseína, durante 24 semanas.

Os dados são apresentados como Média \pm Desvio Padrão e o valor de $\mathrm{P}$ foi obtido pelo Teste $t$ de Student pareado.

${ }^{*} P \leq 0.05$, comparando antes e após os tratamentos dentro de cada grupo. 
A Tabela IX apresenta o número de mulheres nas quais foram encontrados os agentes microbiológicos. Os resultados foram extraídos das lâminas de Colpocitologia (coradas pelo Shorr) das mulheres antes e após tratamento com placebo e isoflavona. As maiores variações na freqüência dos agentes microbiológicos ocorreu no grupo tratado com isoflavona.

TABELA IX - Soma dos Agentes Microbiológicos das mulheres antes e após o tratamento com 40 $\mathrm{mg} / \mathrm{dia}$ de isoflavona e $40 \mathrm{mg} / \mathrm{dia}$ de caseína, durante 24 semanas.

\begin{tabular}{|l|c|c|c|c|}
\hline \multicolumn{1}{|c|}{ AGENTES MICROBIOLÓGICOS } & \multicolumn{2}{|c|}{$\begin{array}{c}\text { PLACEBO } \\
\text { (n=23) }\end{array}$} & $\begin{array}{c}\text { ISOFLAVONA } \\
\text { (n=26) }\end{array}$ \\
\cline { 2 - 6 } & Antes & Depois & Antes & Depois \\
\hline Bacilos de Döederlein & 19 & 15 & 23 & 25 \\
\hline Chlamydia trachomatis & 8 & 9 & 8 & 6 \\
\hline Cocobacilos & 13 & 11 & 15 & 9 \\
\hline Cocos & 13 & 15 & 15 & 8 \\
\hline Leveduras & 4 & 1 & 10 & 4 \\
\hline Fusobacterium & 1 & 0 & 1 & 1 \\
\hline Gardnerella vaginalis & 3 & 1 & 7 & 4 \\
\hline Herpes vírus & 0 & 0 & 1 & 1 \\
\hline HPV & 5 & 3 & 7 & 3 \\
\hline Leptotrix vaginalis & 1 & 0 & 1 & 1 \\
\hline Trichomonas vaginalis & 1 & 0 & 1 & 1 \\
\hline Torulopsis glabrata & 0 & 0 & 1 & 0 \\
\hline \multicolumn{1}{|c|}{ TOTAL } & $\mathbf{6 8}$ & $\mathbf{5 5}$ & $\mathbf{9 0}$ & $\mathbf{6 3}$ \\
\hline
\end{tabular}


A detecção da vaginose bacteriana, através do índice de Nugent, determinado em lâminas de bacterioscopia, coradas pelo Gram é apresentado na Tabela X. No grupo de mulheres que receberam isoflavona, houve diminuição na detecção de vaginose bacteriana (antes $=46,2$ e depois $=26,9 \%$ ).

TABELA X - Índice de Nugent das mulheres antes e após o tratamento com $40 \mathrm{mg} / \mathrm{dia}$ de isoflavona e $40 \mathrm{mg} / \mathrm{dia}$ de caseína, durante 24 semanas.

\begin{tabular}{|c|c|c||c|c|c|c||c|c|}
\hline \multirow{2}{*}{ ÍNDICE DE NUGENT } & \multicolumn{3}{|c|}{$\begin{array}{c}\text { PLACEBO } \\
\text { (n=23) }\end{array}$} & \multicolumn{3}{c|}{$\begin{array}{c}\text { ISOFLAVONA } \\
\text { (n=26) }\end{array}$} \\
\cline { 2 - 9 } & \multicolumn{2}{|c|}{ Antes } & \multicolumn{2}{|c|}{ Depois } & \multicolumn{2}{c|}{ Antes } & \multicolumn{2}{c|}{ Depois } \\
\cline { 2 - 9 } & $\mathbf{( \% )}$ & $\mathbf{n}$ & $\mathbf{( \% )}$ & $\mathbf{n}$ & $\mathbf{( \% )}$ & $\mathbf{n}$ & $\mathbf{( \% )}$ & $\mathbf{n}$ \\
\hline $\begin{array}{c}\mathbf{0}-\mathbf{3} \\
\text { Vagina normal }\end{array}$ & 56,6 & 13 & 43,5 & 10 & 34,6 & 9 & 50,0 & 13 \\
\hline $\mathbf{4 - 6}$ & 21,7 & 5 & 34,8 & 8 & 19,2 & 5 & 23,1 & 6 \\
Colonização intermediária & & & & & & & & \\
\hline $\mathbf{7 - 1 0}$ & 21,7 & 5 & 21,7 & 5 & 46,2 & 12 & 26,9 & 7 \\
Vaginose bacteriana & & & & & & & & \\
\hline
\end{tabular}




\subsection{Exame Colpocitológico}

Avaliando-se o colpocitograma das pacientes deste estudo, segundo critérios de Bethesda, apresentamos na Tabla XI as sugestões de malignidade, prémalignidade, esfregaços inflamatórios, células endocervicais e metaplásicas, HPV e os critérios de restrição à qualidade do esfregaço. Neste último enfocamos dessecamento, estiramento, espessura, celularidade e lâminas acidentadas.

TABELA XI - Achados celulares, segundo critérios de Behtesda, do colpocitograma das mulheres antes e após o tratamento com $40 \mathrm{mg} / \mathrm{dia}$ de isoflavona e $40 \mathrm{mg} / \mathrm{dia}$ de caseína, durante 24 semanas.

\begin{tabular}{|c|c|c|c|c|c|c|c|c|}
\hline \multirow{2}{*}{ CoLPOCITOLOGIA } & \multicolumn{3}{|c|}{$\begin{array}{c}\text { PLACEBO } \\
\text { (n=23) }\end{array}$} & \multicolumn{3}{c|}{$\begin{array}{c}\text { ISOFLAVONA } \\
\text { (n=26) }\end{array}$} \\
\cline { 2 - 9 } & \multicolumn{2}{|c|}{ Antes } & Depois & \multicolumn{2}{c|}{ Antes } & Depois \\
\cline { 2 - 9 } & $(\mathbf{\% )}$ & $\boldsymbol{n}$ & $\mathbf{( \% )}$ & $\boldsymbol{n}$ & $\mathbf{( \% )}$ & $\boldsymbol{n}$ & $\mathbf{( \% )}$ & $\boldsymbol{n}$ \\
\hline Esfregaço inflamatório & 91,3 & 21 & 95,7 & 22 & 100,0 & 26 & 96,2 & 25 \\
\hline AGUS (Bethesda) & 4,3 & 1 & 4,3 & 1 & 0,0 & 0 & 0,0 & 0 \\
\hline AGUSr (Betheda) & 0,0 & 0 & 0,0 & 0 & 0,0 & 0 & 3,8 & 1 \\
\hline HSIL & 4,3 & 1 & 4,3 & 1 & 0,0 & 0 & 0,0 & 0 \\
\hline Células endocervicais & 34,8 & 8 & 21,7 & 5 & 19,2 & 5 & 23,1 & 6 \\
\hline Metaplasia & 39,1 & 9 & 17,4 & 4 & 38,5 & 10 & 26,9 & 7 \\
\hline HPV & 21,7 & 5 & 13,0 & 3 & 26,9 & 7 & 11,5 & 3 \\
\hline Esfregaço dessecado & 73,9 & 17 & 43,5 & 10 & 80,8 & 21 & 30,8 & 8 \\
\hline Esfregaço distendido & 4,3 & 1 & 8,7 & 2 & 15,4 & 4 & 7,7 & 2 \\
\hline Esfregaço espesso & 17,4 & 4 & 26,1 & 6 & 15,4 & 4 & 7,7 & 2 \\
\hline Esfregaço paucicelular & 4,3 & 1 & 4,3 & 1 & 0,0 & 0 & 0,0 & 0 \\
\hline Lâminas quebradas & 4,3 & 1 & 8,7 & 2 & 11,5 & 3 & 11,5 & 3 \\
\hline
\end{tabular}

Legenda:

AGUS - Células glandulares atípicas de significado indeterminado

AGUSr - Células glandulares atípicas de significado indeterminado (provavelmente reacional)

HSIL - Lesão intra-epitelial pavimentosa de alto grau.

HPV - Papiloma Vírus Humano. 


\subsection{Sinais e sintomas da menopausa}

\subsubsection{Queixas Clínicas}

Da aplicação de um questionário, com 28 itens, antes de iniciar o tratamento, até o término do estudo, mensalmente, num período de 24 semanas, compilamos as informações no grupo tratado com isoflavona (26 mulheres) e no grupo placebo (23 mulheres). Estes dados foram agrupados em sinais e sintomas vasomotores, somáticos, psicossomáticos e urogenitais.

A análise da Tabela XII possibilita uma avaliação do efeito da isoflavona e do placebo em diferentes tipos de queixas clínicas. Com relação aos sintomas vasomotores, não houve grande diferença na porcentagem de melhora quando comparado o grupo controle e o tratado. Por outro lado, quando analisados os sintomas somáticos, observa-se maior porcentagem de melhora na maioria dos sintomas nas mulheres que receberam isoflavona, no entanto, em relação à mialgia e formigamento a melhora foi maior nas pacientes que receberam placebo. Os outros sintomas avaliados são agrupados em sintomas psicossomáticos, no qual se observou diminuição marcante das queixas nas mulheres que receberam isoflavona para todos os sintomas avaliados, exceto para fadiga mental, no qual a porcentagem de melhora foi semelhante entre os dois grupos. Por último, avaliaram-se as queixas urogenitais e a melhora das queixas foi maior no grupo tratado com isoflavona (TABELA XII e FIGURA 19). 
TABELA XII - Soma das queixas clínicas antes e após o tratamento com isoflavona e uso de placebo ( $40 \mathrm{mg} / \mathrm{dia}$ ), no período de 24 semanas. Os dados foram apresentados como média \pm desvio padrão e o valor de $\mathrm{P} \leq 0,05$ (teste $t$ de student)

\begin{tabular}{|c|c|c|c|c|}
\hline \multirow[t]{2}{*}{ QUEIXAS CLÍNICAS } & \multicolumn{2}{|c|}{$\begin{array}{l}\text { PLACEBO } \\
(\mathrm{n}=23)\end{array}$} & \multicolumn{2}{|c|}{$\begin{array}{l}\text { ISOFLAVONA } \\
(n=26)\end{array}$} \\
\hline & Antes & Depois & Antes & Depois \\
\hline \multicolumn{5}{|c|}{ SINTOMAS VASOMOTORES } \\
\hline Ondas de calor & 36,5 & 13,5 & 47,5 & 24,0 \\
\hline Sudorese & 22,5 & 7,0 & 47,0 & 20,5 \\
\hline Palpitação & 15,0 & 6,0 & 18,0 & 4,0 \\
\hline SOMA & 74,0 & 26,5 & 112,5 & 48,5 \\
\hline MÉDIA \pm DESVIO PADRÃO & $24,7 \pm 10,9$ & $8,8 \pm 4,1$ & $37,5 \pm 16,9$ & $16,2 \pm 10,7$ \\
\hline $\boldsymbol{P}$ (comparando antes e após no mesmo grupo) & \multicolumn{2}{|c|}{0,06} & \multicolumn{2}{|c|}{0,03 * } \\
\hline \multicolumn{5}{|c|}{$\mathbf{P}=\mathbf{0 , 1 8}$ comparando grupo placebo e grupo tratado com isoflavona antes do início do tratamento } \\
\hline \multicolumn{5}{|c|}{ SINTOMAS SOMÁTICOS } \\
\hline Zumbido & 14,0 & 8,0 & 17,0 & 2,0 \\
\hline Tonturas & 11,0 & 4,5 & 16,0 & 6,0 \\
\hline Mialgia & 26,0 & 14,5 & 22,0 & 17,0 \\
\hline Artralgia & 43,0 & 27,0 & 31,0 & 19,5 \\
\hline Neuralgia & 12,0 & 11,0 & 22,0 & 13,5 \\
\hline Dor lombar & 27,0 & 14,5 & 24,0 & 16,0 \\
\hline Dor baixo ventre & 14,0 & 5,0 & 13,5 & 6,5 \\
\hline Flacidez & 7,0 & 9,0 & 20,0 & 12,5 \\
\hline Pele do Corpo & 32,0 & 26,5 & 39,0 & 23,0 \\
\hline Formigamento & 6,0 & 3,5 & 13,0 & 10,0 \\
\hline SOMA & 192,0 & 123,5 & 217,5 & 126,0 \\
\hline MÉDIA \pm DESVIO PADRÃO & $19,2 \pm 12,2$ & $12,4 \pm 8,5$ & $21,8 \pm 8,1$ & $12,6 \pm 6,6$ \\
\hline $\boldsymbol{P}$ (comparando antes e após no mesmo grupo) & \multicolumn{2}{|c|}{$0,004^{*}$} & \\
\hline \multicolumn{5}{|c|}{$\mathbf{P}=\mathbf{0 , 3 1}$ comparando grupo placebo e grupo tratado com isoflavona antes do início do tratamento } \\
\hline \multicolumn{5}{|c|}{ SINTOMAS PSICOSSOMÁTICOS } \\
\hline Irritabilidade & 36,0 & 27,6 & 42,0 & 16,0 \\
\hline Ansiedade & 43,0 & 27,0 & 42,0 & 15,5 \\
\hline Depressão & 25,0 & 10,5 & 32,0 & 6,0 \\
\hline Amnésia & 38,0 & 29,5 & 36,0 & 22,5 \\
\hline Diminuição da libido & 40,0 & 39,0 & 45,0 & 29,0 \\
\hline Cefaléia & 21,0 & 15,5 & 31,0 & 10,0 \\
\hline Fadiga mental & 29,0 & 13,0 & 29,0 & 14,5 \\
\hline Insônia & 31,0 & 19,0 & 34,0 & 9,5 \\
\hline Melancolia & 31,0 & 15,5 & 27,0 & 5,0 \\
\hline SOMA & 294,0 & 196,6 & 318,0 & 128,0 \\
\hline MÉDIA \pm DESVIO PADRÃO & $32,7 \pm 7,2$ & $21,8 \pm 9,4$ & $35,3 \pm 6,4$ & $14,2 \pm 7,8$ \\
\hline $\boldsymbol{P}$ (comparando antes e após no mesmo grupo) & \multicolumn{2}{|c|}{$0,0003^{*}$} & \multicolumn{2}{|c|}{$\begin{array}{c}\leq 0,0001^{*} \\
\text { inicio do tratamento }\end{array}$} \\
\hline \multicolumn{5}{|c|}{$\mathbf{P}=\mathbf{0 , 1 3}$ comparando grupo placebo e grupo tratado com isoflavona antes do início do tratamento } \\
\hline \multicolumn{5}{|c|}{ UROGENITAIS } \\
\hline Incontinência urinária & 18,0 & 10,5 & 12,0 & 5,0 \\
\hline Dor miccional & 8,0 & 0,0 & 5,0 & 0,5 \\
\hline Ressecamento Vaginal & 25,0 & 18,5 & 44,0 & 32,5 \\
\hline Dispaurenia & 8,0 & 7,0 & 34,0 & 20,5 \\
\hline Sinusorragia & 0,5 & 0,0 & 0,0 & 0,5 \\
\hline SOMA & 59,5 & 36,0 & 95,0 & 59,0 \\
\hline MÉDIA \pm DESVIO PADRÃO & $11,9 \pm 9,6$ & $7,2 \pm 7,8$ & $19,0 \pm 19,1$ & $11,8 \pm 14,2$ \\
\hline $\boldsymbol{P}$ (comparando antes e após no mesmo grupo) & \multicolumn{2}{|c|}{$0,05^{*}$} & \multirow{2}{*}{\multicolumn{2}{|c|}{$\frac{0,04^{*}}{\text { início do tratamento }}$}} \\
\hline$P=0,33$ comparando grupo placebo e grup & atado com isof & avona antes & & \\
\hline
\end{tabular}




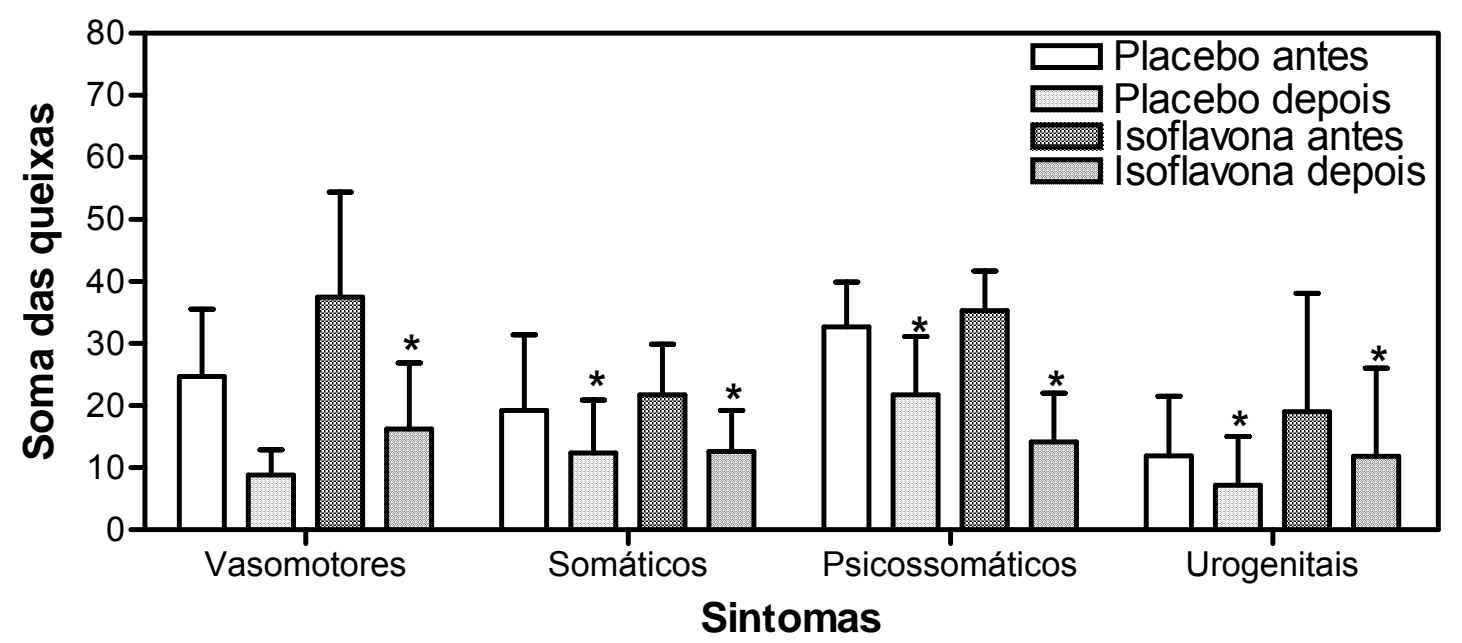

FIGURA 19 - Representação gráfica das queixas clínicas das mulheres antes e após o tratamento com $40 \mathrm{mg} /$ dia de isoflavona e $40 \mathrm{mg} /$ dia de caseína, durante 24 semanas.

Os dados são apresentados como Média \pm Desvio Padrão e o valor de $\mathrm{P}$ foi obtido pelo Teste $t$ de Student pareado.

${ }^{*} p \leq 0.05$, comparando antes e após os tratamentos dentro de cada grupo.

Com o objetivo de verificar as dez principais queixas das mulheres antes de iniciar o estudo e comparar se estas queixas são semelhantes nos dois grupos, colocou-se, em ordem decrescente, as queixas mais citadas. Das dez principais queixas, observou-se que sete estavam presentes nos dois grupos, demonstrando, que às mulheres na pós-menopausa apresentam homogeneidade em relação às queixas clínicas (TABELA XIII). As queixas que estão coloridas são aquelas que apareceram como uma das dez mais citadas nos dois grupos.

TABELA XIII - Dez maiores queixas nas mulheres entrevistadas, antes do início do tratamento, nos grupos usando placebo e no grupo medicado com isoflavona, em ordem decrescente e a soma das mesmas.

\begin{tabular}{|c|c|c|c||c|}
\hline \multirow{2}{*}{ ORDEM } & \multicolumn{2}{|c|}{ PLACEBO } & \multicolumn{2}{c|}{ ISOFLAVONA } \\
\cline { 2 - 5 } & QUEIXA & SOMA & QUEIXA & SOMA \\
\hline $\mathbf{1}^{\mathbf{a}}$ & Artralgia & 43 & Ondas de calor & $\mathbf{4 7 , 5}$ \\
\hline $\mathbf{2}^{\mathbf{a}}$ & Ansiedade & $\mathbf{4 3}$ & Sudorese & 47 \\
\hline $\mathbf{3}^{\mathbf{a}}$ & Diminuição da libido & $\mathbf{4 0}$ & Diminuição da libido & $\mathbf{4 5}$ \\
\hline $\mathbf{4}^{\mathbf{a}}$ & Amnésia & $\mathbf{3 8}$ & Ressecamento Vaginal & 44 \\
\hline $\mathbf{5}^{\mathbf{a}}$ & Ondas de calor & $\mathbf{3 6 , 5}$ & Ansiedade & 42 \\
\hline $\mathbf{6}^{\mathbf{a}}$ & Irritabilidade & $\mathbf{3 6}$ & Irritabilidade & $\mathbf{4 2}$ \\
\hline $\mathbf{7}^{\mathbf{a}}$ & Pele do Corpo & $\mathbf{3 2}$ & Pele do Corpo & $\mathbf{3 9}$ \\
\hline $\mathbf{8}^{\mathbf{a}}$ & Melancolia & 31 & Amnésia & 36 \\
\hline $\mathbf{9}^{\mathbf{a}}$ & Insônia & $\mathbf{3 1}$ & Insônia & 34 \\
\hline $\mathbf{1 0}^{\mathbf{a}}$ & Fadiga mental & 29 & Dispaurenia & 34 \\
\hline
\end{tabular}


Além disso, é importante verificar se a porcentagem de melhora das queixas acima citadas foi semelhante nos dois grupos. Para tal, foi organizada a Tabela XIV, que apresenta, também em ordem decrescente, as queixas que tiveram maior porcentagem de melhora após os tratamentos com placebo ou isoflavona.

TABELA XIV - Porcentagens de melhoras com isoflavona e placebo, quando comparada à soma das queixas antes e após o tratamento de 24 semanas.

\begin{tabular}{|c|c||c|c||c|}
\hline \multirow{2}{*}{ ORDEM } & \multicolumn{2}{|c|}{ PLACEBO } & \multicolumn{2}{c|}{ ISOFLAVONA } \\
\cline { 2 - 5 } & QUEIXA & $\mathbf{\%}$ & QUEIXA & $\mathbf{\%}$ \\
\hline $\mathbf{1}^{\mathbf{a}}$ & Dor miccional & $\mathbf{1 0 0 , 0}$ & Dor miccional & $\mathbf{9 0 , 0}$ \\
\hline $\mathbf{2}^{\mathbf{a}}$ & Sinosorragia & 100,0 & Zumbido & 88,2 \\
\hline $\mathbf{3}^{\mathbf{a}}$ & Sudorese & 68,8 & Melancolia & $\mathbf{8 1 , 5}$ \\
\hline $\mathbf{4}^{\mathbf{a}}$ & Dor baixo ventre & 64,3 & Depressão & $\mathbf{8 1 , 3}$ \\
\hline $\mathbf{5}^{\mathbf{a}}$ & Ondas de calor & 63,0 & Palpitação & $\mathbf{7 7 , 7}$ \\
\hline $\mathbf{6}^{\mathbf{a}}$ & Palpitação & $\mathbf{6 0 , 0}$ & Insônia & 72,1 \\
\hline $\mathbf{7}^{\mathbf{a}}$ & Tonturas & $\mathbf{5 9 , 1}$ & Cefaléia & 67,7 \\
\hline $\mathbf{8}^{\mathbf{a}}$ & Depressão & $\mathbf{5 8 , 0}$ & Ansiedade & 63,1 \\
\hline $\mathbf{9}^{\mathbf{a}}$ & Fadiga mental & 55,2 & Tonturas & $\mathbf{6 2 , 5}$ \\
\hline $\mathbf{1 0}^{\mathbf{a}}$ & Melancolia & $\mathbf{5 0 , 0}$ & Irritabilidade & 61,9 \\
\hline
\end{tabular}

Conforme pode ser observado na tabela acima, em relação à porcentagem de melhora, houve apenas cinco queixas, das dez com maior porcentagem de melhora em cada grupo, comum aos dois grupos, sendo a porcentagem de melhora nitidamente maior, para a maioria das queixas clínicas, no grupo tratado com isoflavona. É interessante observar também, que as queixas mais citadas antes do início do tratamento, não necessariamente, apresentaram maior porcentagem de melhora ao final deste.

\subsection{2 Índice de Kuppermann}

A aplicação de um questionário com 28 itens, antes de iniciar o tratamento, mensalmente, até o término do estudo (24 semanas), permitiu a obtenção do índice de Kupperman que representa as queixas antes e após o tratamento com isoflavona e placebo. A Tabela XV apresenta os valores das somas das queixas de cada mulher no índice de Kupperman, a soma das queixas de todas as mulheres de cada grupo, a média \pm desvio padrão e o valor de $\mathrm{P}$ para antes e após o tratamento. 
TABELA XV - Determinação do índice de Kuppermann antes e após o tratamento com isoflavona ou uso de placebo (40mg/dia), no período de 24 semanas.

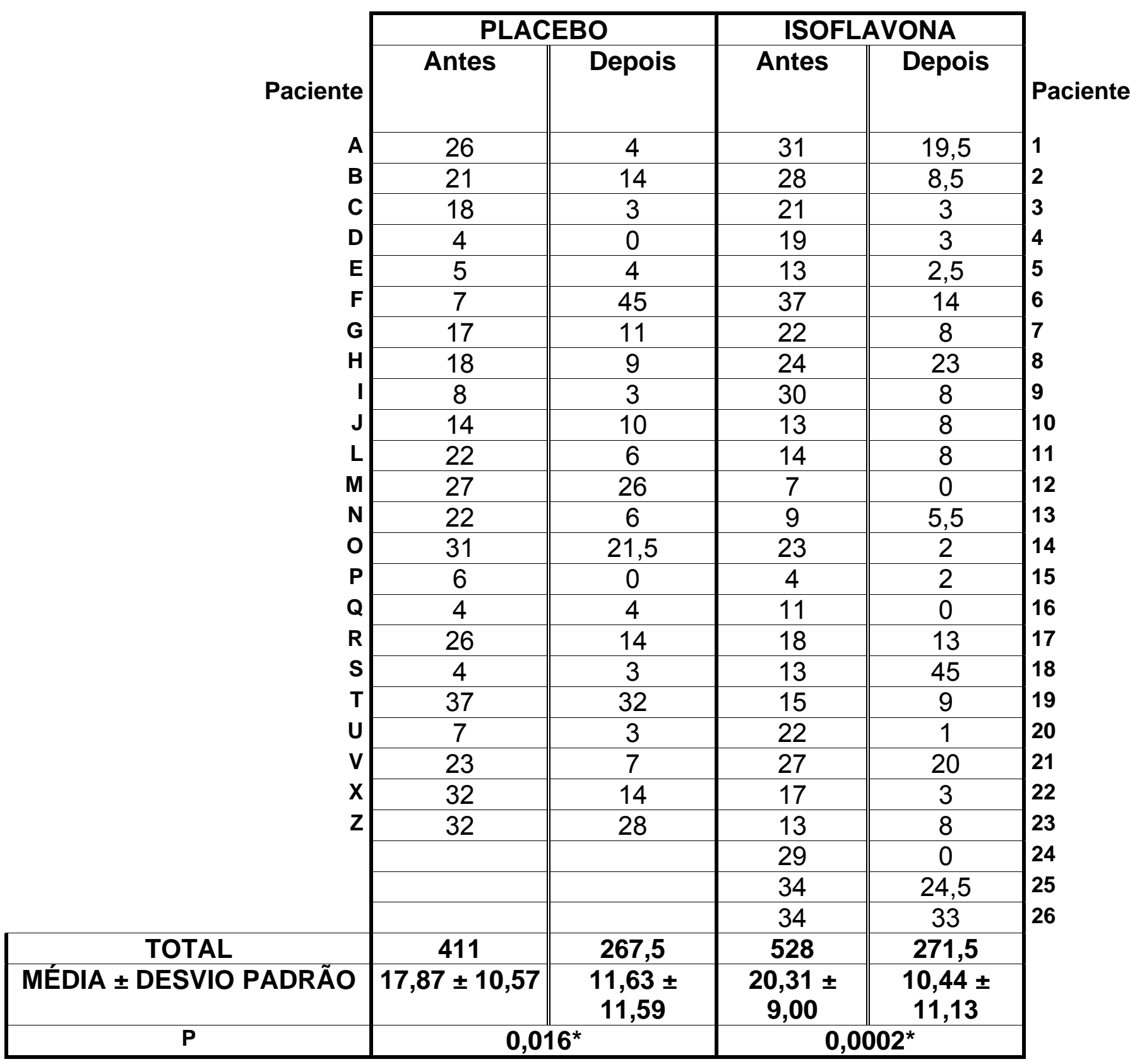

Os dados são apresentados como Média \pm Desvio Padrão e o valor de $\mathrm{P}$ foi obtido pelo Teste $t$ de Student pareado.

${ }^{*} P \leq 0.05$, comparando antes e após os tratamentos dentro de cada grupo.

Conforme pode ser observado pela determinação do índice de Kuppermann, houve diminuição no índice, após o tratamento tanto de placebo como no grupo tratado com isoflavona. No entanto, a diminuição do índice foi mais significativa no grupo que recebeu a isoflavona. Esses dados são importantes, uma vez que mostram que mesmo havendo melhora com o uso apenas do placebo, a isoflavona, melhorou de forma marcante a queixa dos sintomas avaliados pelo questionário. 


\subsection{Metabólitos da isoflavona}

Num estudo paralelo, utilizando a urina das mesmas mulheres avaliadas neste projeto, determinou-se os níveis urinários da daidzeína e genisteína, metabólitos da soja, que nos permitiu avaliar a adesão das pacientes ao tratamento como também se a fonte exógena de soja, pela alimentação, pudesse estar interferindo nos nossos resultados.

Os metabólitos da isoflavona representados pela determinação dos níveis urinários da daidzeína e genisteína, antes e após 24 semanas de tratamento com 40 mg de caseína e isoflavona, em 22 pacientes do grupo placebo e 25 pacientes do grupo tratado, respectivamente, estão apresentados na Tabela XVI.

Tabela XVI - Metabólitos urinários da isoflavona antes e após 24 semanas de tratamento nos grupos placebo e tratado.

\begin{tabular}{|c|c|c|c|c|}
\hline Parâmetro & \multicolumn{2}{|c|}{ PLACEBO } & \multicolumn{2}{c|}{ TRATADO } \\
\cline { 2 - 5 } & ANTES & DEPOIS & ANTES & DEPOIS \\
\hline Daidzeína $(\mu \mathbf{g} / \mathbf{m L})$ & $1,11 \pm 1,13$ & $1,27 \pm 1,09$ & $2,57 \pm 2,75$ & $12,12 \pm 13,52$ \\
\hline $\mathbf{P}$ & \multicolumn{2}{|c|}{0,7273} & \multicolumn{2}{c|}{$0,0193^{*}$} \\
\hline Genisteína $(\boldsymbol{\mu} \mathbf{g} / \mathbf{m l})$ & $0,35 \pm 0,35$ & $0,47 \pm 0,57$ & $0,58 \pm 0,67$ & $5,91 \pm 9,77$ \\
\hline $\mathbf{P}$ & \multicolumn{2}{|c|}{0,4842} & \multicolumn{2}{c|}{$0,0483^{*}$} \\
\hline
\end{tabular}

Os dados são apresentados como Média \pm Desvio Padrão.

${ }^{*} p \leq 0,05$, comparado com $T$ (Teste $t$ de Student pareado). 


\section{DISCUSSÃO}

A busca de terapias para melhorar os sintomas e prevenir doenças relacionadas com a deficiência de estrogênios na peri e pós-menopausa, sem a ocorrência dos efeitos indesejáveis associados com a reposição hormonal estroprogestiva, levou a descoberta da ação estrogênica de alguns compostos de origem vegetal, os chamados fitoestrógenos. A isoflavona é um fitoestrógeno presente em grande quantidade na soja e tem sido amplamente estudada atualmente. Estes compostos são comercializados livremente na forma de alimentos dietéticos ou extratos de soja, purificados por métodos que nem sempre excluem outras proteínas, que também podem ter efeitos farmacológicos (NAFTOLIN \& STANBURY, 2002).

Dessa forma, vários estudos tem sido conduzidos na tentativa de caracterizar os efeitos da isoflavona, principalmente em mulheres menopausadas com contraindicação de reposição hormonal estroprogestiva. A grande dificuldade encontrada na comparação dos resultados de estudos usando isoflavona é a diferença existente nos modos de administração da mesma, bem como a presença deste composto em vários alimentos usados no dia-a-dia. Dependendo da quantidade de tais alimentos ingeridos pelas mulheres que fazem parte dos estudos com isoflavona, a concentração plasmática deste composto e seus metabólitos podem variar de forma drástica, interferindo nos resultados.

O uso de cápsulas, com concentrações conhecidas de isoflavona, facilita a condução e análise dos estudos, uma vez que doses uniformes e menores variações na absorção, proporcionam concentrações plasmáticas semelhantes entre as usuárias. Dessa forma, para o presente estudo, optou-se pelo uso de cápsulas contendo isoflavona e não de suplemento alimentar. A dose escolhida para administração foi de $40 \mathrm{mg} /$ dia de isoflavona, essa dose é relativamente baixa quando comparada com outros estudos, que usam doses maiores como de 60 mg/dia (NAHAS et al., 2004), 120 mg/dia (KAARI et al., 2006) e até 150 mg/dia (UNFER et al., 2004). No entanto, como ainda não estão estabelecidas as doses eficazes para tratar os principais sinais e sintomas da menopausa e nem a faixa terapêutica da isoflavona, optou-se neste estudo, pelo uso da dose de $40 \mathrm{mg} / \mathrm{dia}$ de 
isoflavona, já que essa dose parece ser suficiente para causar os efeitos benéficos, sem o risco de efeitos adversos (ANVISA, 2002).

Para o presente estudo, foram entrevistadas 354 mulheres menopausadas sobre 0 interesse no uso de isoflavona para aliviar os sinais e sintomas da menopausa e a disponibilidade em participar do estudo. Os critérios mais freqüentes de exclusão foram 30,5\% por uso de medicamento para distúrbios neurovegetativos e mentais, 11,3\% por diabetes, 9,4\% por serem fumantes, 9,4\% por já usarem $\mathrm{TRH}, 7,5 \%$ por dislipidemias, 7,5\% por IMC alto, 5,6\% por osteoporose, 5,6\% por gastrite, 3,8\% por pouco tempo do início da menopausa e 3,8\% não se interessaram em participar. Curiosamente, $1,88 \%$ das entrevistadas não iam ao médico há mais de cinco anos. Das entrevistadas foram selecionadas 52 mulheres, das quais 23 constituíram o grupo controle, recebendo caseína como placebo e 26 receberam isoflavona, constituindo o grupo tratado. Nos dois casos, as doses usadas foram iguais. Os grupos participantes se mostraram homogêneos com relação às características físicas e idades de menarca, sexarca, anos após o início da menopausa e número de parceiros, sendo diferentes apenas em relação à paridade.

Analisando o Anexo III observamos que no grupo controle e no grupo tratado com isoflavona 39 mulheres fizeram uso anterior de TRH e os motivos mais freqüentes de desistência foram preferência por fitoterápicos, sangramentos, problemas mamários, suspensão do uso por parte do médico, retenção hídrica, medo de câncer de mama, aumento do útero, cirurgia vascular anterior, ocorrência de efeitos adversos (náusea, prurido, ganho de peso, dor no ventre, dificuldade em encontrar o medicamento prescrito e recusa do uso de terapia estroprogestiva). Outras, no entanto, alegaram falta de dinheiro para comprar os medicamentos ou, simplesmente, abandonaram o tratamento. Esses dados mostram que as mulheres participantes do estudo estavam interessadas na obtenção de métodos alternativos para aliviar os sinais e sintomas desagradáveis da menopausa.

Os resultados obtidos mostraram que a isoflavona exerceu efeitos benéficos sobre a maturação epitelial vaginal, visto que houve diminuição significativa das células parabasais e aumento significativo das células superficiais cianofílicas nos colpocitogramas (convencional e coleta úmida) e no urocitograma. Foi observado, 
ainda, aumento significativo das células superficiais eosinofílicas no urocitograma. Não houve alteração significativa das células intermediárias em nenhum dos métodos de análise. Ocorreu, também, aumento significativo do valor de maturação nos três tipos de material; aumento do índice de picnose na colpocitologia (coleta úmida) e no urocitograma e o índice de eosinofilia apenas no urocitograma. Além disso, observaram-se alterações benéficas na microbiota vaginal, com aumento da colonização por bacilos de Döederlein e diminuição da vaginose bacteriana. Com relação aos sinais e sintomas desagradáveis da menopausa, a isoflavona proporcionou diminuição do número de queixas.

\subsection{Maturação do epitélio vaginal}

$\mathrm{Na}$ colpocitologia, o uso da isoflavona diminuiu a porcentagem de células parabasais $(P=0,003)$, aumentou a porcentagem das células superficiais cianofílicas $(P=0,006)$, aumentou de forma não significativa a porcentagem das células intermediárias $(P=0,054)$ e superficiais eosinofílicas $(P=0,18)$. Com o uso do placebo não houve alterações significativas em nenhum dos tipos celulares avaliados, no entanto, ocorreu um pequeno aumento no número de células parabasais $(P=0,094)$. Na menopausa, observam-se esfregaços vaginais hipotróficos ou até acentuadamente atróficos. O esfregaço atrófico se caracteriza pela ausência de células superficiais eosinofílicas e por porcentagem variável de células profundas. O grau de atrofia é tanto maior quanto maior a quantidade de células profundas encontradas no esfregaço. Na pós-menopausa o Índice de Maturação sofre desvio, com predomínio de células parabasais, situação que pode ser mudada com a administração de estrógeno (LUSTOSA et al., 2002). No presente estudo, observou-se diminuição significativa das células parabasais, aumento das células superficiais cianofílicas e superficiais eosinofílicas. Esses dados nos reportam que a isoflavona exerceu seu efeito estrogênico sobre o epitélio vaginal.

Esses resultados são, em parte, semelhantes àqueles obtidos por Uesugi et al. (2003), que avaliaram o efeito de $60 \mathrm{mg} / \mathrm{dia}$ de isoflavona em 22 mulheres menopausadas. Houve diminuição das células parabasais $(P=0,026)$ e aumento das células intermediárias $(P=0,006)$ após o tratamento com isoflavona. Por outro lado, 
esses autores observaram diminuição não significativa das células superficiais após o tratamento e não houve alteração no grupo placebo. O aumento de células superficiais é o melhor indicativo da estimulação estrogênica, no entanto, não é observado em todas as mulheres tratadas com isoflavona (BAIRD et al., 1995). Neste último estudo, foi pesquisado o efeito de uma dieta contendo $165 \mathrm{mg} / \mathrm{dia}$ de isoflavona sobre as células superficiais, observando um aumento das mesmas após a dieta, porém com grande variação entre as mulheres.

Manonai et al. (2006) avaliaram o efeito de uma dieta contendo $25 \mathrm{~g}$ de produtos obtidos da soja, equivalendo ao consumo diário de $50 \mathrm{mg}$ de isoflavona, durante três meses em 36 mulheres tailandesas em peri e pós-menopausa. Como controle, usou um grupo placebo que consumiu dieta isocalórica, mas sem a adição de soja. Após os três meses de estudo não foi observado diferenças nas porcentagens de células parabasais, células intermediárias e células superficiais. Dados estes, que contradizem os resultados obtidos no presente estudo.

É fácil perceber que existem controvérsias quanto aos efeitos estrogênicos das isoflavonas. Alguns autores demonstram que isoflavona não confere importante efeito estrogênico sobre a maturação do epitélio vaginal. No entanto, Chiechi et al. (2003), corroborando com nossos resultados, concluíram que dieta com fitoestrógenos previne os efeitos da menopausa e a atrofia vaginal.

Em nosso estudo, além da citologia hormonal em lâminas colhidas durante a consulta ginecológica, foi feita a citologia hormonal nas lâminas obtidas em meio úmido, (com material colhido para o exame direto a fresco). O uso desta metodologia foi para fugir dos esfregaços insatisfatórios que muitas vezes ocorrem devido a pouca descamação epitelial que algumas pacientes pós-menopausadas apresentam. Os I.M.s não foram diferentes dos obtidos anteriormente, mas o dessecamento nas lâminas em meio úmido foi menor, o que permitiu uma melhor análise do parâmetro hormonal das nossas pacientes. Neste tipo de coleta, houve diminuição no número das células parabasais $(P=0,04)$ e aumento das células superficiais cianofílicas $(P=0,008)$, sem alterações significativas nas células intermediárias e superficiais eosinofílicas das pacientes tratadas com isoflavona. Nas mulheres que receberam placebo, não encontramos alterações celulares 
significativas.

A citologia hormonal é um ramo da morfologia citológica pouco usada atualmente, apesar de ser um método de baixo custo e resolutividade satisfatória para avaliar os efeitos de substâncias potencialmente estrogênicas no epitélio vaginal. Além do colpocitograma, a citologia hormonal pode ser feita, também, através do urocitograma que é processado a partir da coleta da urina da paciente. Devido à facilidade na obtenção do material, este método de coleta não é invasivo e representa uma alternativa interessante para as mulheres menopausadas, uma vez que a maioria delas apresenta atrofia, estenose vaginal e relatam desconforto durante a coleta dos exames colpocitológicos convencionais.

No presente estudo, a citologia hormonal feita pelo urocitograma apresentou resultados semelhantes aos anteriores, já apresentados, porém com maior sensibilidade. Houve diminuição das células parabasais $(P=0,008)$, aumento das células superficiais eosinofílicas $(P=0,002)$ e cianofílicas $(P=0,013)$, sem alterações significativas das células intermediárias nas mulheres tratadas com isoflavona. As mulheres que receberam placebo não sofreram estas alterações celulares não foram significativas. Este resultado é interessante, uma vez que comprova que o urocitograma pode substituir o colpocitograma, pois é um método menos incômodo, de fácil obtenção do material e com sensibilidade igual ou superior a coleta anteriormente citada, visto nos dois casos estarmos avaliando o mesmo epitélio hormônio-dependente, o pluriestratificado pavimentoso não-ceratinizado.

A determinação dos índices de picnose, eosinofilia e valor de maturação foram determinados no colpocitograma, colpocitograma (coleta úmida) e urocitograma com o objetivo de confirmar o efeito da isoflavona sobre o epitélio vaginal. O Índice de picnose representa a porcentagem de células superficiais cianofílicas somadas às células superficiais eosinofílicas (células com núcleos picnóticos). Uma vez que foi observado, no índice de maturação, aumento na porcentagem destes tipos celulares após o uso de isoflavona, espera-se que o mesmo seja observado no índice de picnose. De fato, houve aumento no índice de picnose no colpocitograma (coleta úmida) $(P=0,01)$, no urocitograma $(P=0,006)$ e aumento não significativa no colpocitograma convencional $(P=0,08)$ após o uso da isoflavona e nenhuma 
alteração após o uso do placebo. O outro índice avaliado, índice de eosinofilia, que por sua vez expressam a maturação máxima do epitélio vaginal, através da porcentagem de células superficiais eosinofílicas, obteve-se aumento significativo neste índice apenas no urocitograma, semelhante ao que foi observado no índice de maturação, no qual a porcentagem de células superficiais eosinofílicas foi significativamente maior somente neste método.

Houve diminuição, não significativa após o uso de isoflavona, das células superficiais eosinofílicas no índice de maturação apenas na colpocitologia avaliada pela coleta úmida. Essa diminuição se refletiu no baixo índice de eosinofilia avaliado neste método. Não houve alteração significativa nos outros métodos nem nas mulheres que receberam placebo.

Como o valor de maturação, representa a proporção de células intermediárias e superficiais, este método foi utilizado para comparar a maturação celular no epitélio escamoso pluriestratificado não ceratinizado. De uma forma geral, foi observado no nosso estudo através do Índice de Maturação, aumento da porcentagem das células superficiais e das células intermediárias, após o uso da isoflavona. Estes valores foram observados também no valor de maturação no colpocitograma convencional $(P=0,007)$, no colpocitograma coleta úmida $(P=0,004)$ e no urocitograma $(p=0,0008)$, atestando desta forma a importância das isoflavonas como tratamento para menopausa, visto seu efeito estimulador no crescimento epitelial vaginal.

No grupo placebo não houve variação significativa em nenhum índice avaliados através dos métodos de colpocitograma convencional ou colpocitograma através de coleta úmida; mas no urocitograma observou-se diminuição significativa no índice de picnose e no valor de maturação. Essa observação, juntamente com a comparação dos outros valores obtidos e já apresentados, confirma a idéia de que o urocitograma é um método útil e sensível para análise da maturação epitelial vaginal, embora pouco empregado na rotina de ginecologia.

Comparando nossos achados com os apresentados pela literatura apontamos um estudo de Nikander et al., (2005), no qual mulheres com história prévia de câncer de mama receberam $114 \mathrm{mg}$ de isoflavona/dia, em duas doses. Neste estudo foram 
avaliados exames pélvicos, ultrasonografia transvaginal, coleta de sangue, esfregaço cervical e vaginal, biopsia endometrial e também aplicação de questionário para se avaliar sintomas da menopausa. Quatro mulheres foram excluídas por apresentarem sangramento vaginal, usando placebo. O uso da isoflavona não foi eficiente no ressecamento vaginal e nem na maturação, porém o número de células parabasais aumentou nas mulheres usando placebo. Os receptores para estrogênio, progesterona e expressão de Ki-67 foram determinados em cortes histológicos pela técnica de imunohistoquímica. O Ki-67, antígeno nuclear ligado à proliferação celular, que reflete a ação estrogênica sobre o endométrio apareceu em 3 das 24 mulheres tratadas e em nenhuma paciente do grupo placebo, o que reflete a ação estrogênica da isoflavona nesse estudo sobre o endométrio

Corroborando com os resultados do presente estudo, o estudo conduzido com um grupo de 187 mulheres pós-menopausadas divididas em 03 grupos. Cinqüenta e oito mulheres fizeram parte do primeiro grupo que consumiram dieta rica em soja (20 $30 \mathrm{mg} / \mathrm{dia}$ de isoflavona), quantidade semelhante àquela consumida, usualmente, pelas mulheres orientais que apresentam baixo índice de cânceres estrógenodependentes, como o de mama e o de endométrio. Estas pacientes, apresentam também, poucas queixas clínicas relacionadas à deficiência de estrogênio, típicas da menopausa. O segundo grupo contou com a participação de 53 mulheres usando $\mathrm{TRH}$, no qual 30\% delas ovariectomizadas receberam $50 \mu \mathrm{g}$ de estradiol pela via transdérmica e 56\% receberam $50 \mu \mathrm{g}$ de estradiol por via transdérmica associado com nomegestrol 2,5 mg/dia. O terceiro grupo com 14\% das mulheres, receberam terapia seqüencial cíclica de estradiol $50 \mu \mathrm{g}$ pela via transdérmica e $5 \mathrm{mg}$ de nomegestrol 12 dias/mês e, por último, um grupo placebo. Acompanhou-se a citologia hormonal das pacientes no início do tratamento e seis meses depois, tendo obtido um aumento do V.M. de $39,1 \%$ no grupo tratado com reposição hormonal; $12,6 \%$ no grupo da dieta rica em soja e $3 \%$ no grupo placebo. O I.P. aumentou $34,3 \%$ no grupo de reposição estroprogestiva; $15,5 \%$ no grupo da dieta rica em isoflavona e 0,7\% no grupo placebo (CHIECHI et al., 2003).

Wilcox et al. (1990) estudaram 25 mulheres pós-menopausadas durante 16 semanas. Nas duas primeiras quinzenas as mulheres utilizaram suas dietas usuais e durante o período experimental a dieta foi suplementada por $45 \mathrm{~g}$ de farinha de soja, 
$10 \mathrm{~g}$ de red clover ou $25 \mathrm{~g}$ de semente de linhaça, por dia. Para determinação do LH e FSH no sangue, bem como para o valor de maturação, foram colhidos o sangue e a secreção vaginal, durante o experimento (quinzenalmente), bem como 2 e 8 semanas após o término do tratamento. Foi calculado o V.M. o qual apresentou um aumento significativo de 30,8 antes para 43,6, duas semanas após o tratamento, nas mulheres que consumiram dieta rica em isoflavona. Os melhores resultados de V.M. foram obtidos nos grupos que consumiram e farinha de soja $(P<0,05)$ e semente de linhaça $(P<0,02)$, mas com red clover $(P=0,11)$. Apesar dos achados desta pesquisa serem promissores no tocante à aplicação da soja para melhoria da citologia vaginal a literatura ainda aponta controvérsias sobre os benefícios dos fitoestrógenos sobre a citologia vaginal.

Um outro estudo conduzido por seis meses e tendo a participação de 50 mulheres menopausadas com intolerância ou contra indicação para reposição estroprogestiva investigou-se o efeito do tratamento com $60 \mathrm{mg} / \mathrm{dia}$ de isoflavona de soja em cápsulas, tomadas 2 vezes ao dia em 25 mulheres, avaliando-se o perfil hormonal destas pacientes pela colpocitologia. Para comparação, outro grupo de 25 mulheres recebeu a mesma dose e o mesmo número de cápsulas diárias, contendo caseína do leite, como grupo placebo. Calculou-se o valor de maturação de Meisels a partir de citologia vaginal e não houve mudanças em relação a este parâmetro nas mulheres que receberam isoflavona, no entanto, o grupo placebo apresentou redução significativa no valor de maturação quando comparado com os valores basais. Esses dados sugerem que com o uso da isoflavona ocorre manutenção do epitélio vaginal enquanto no grupo placebo, verifica-se redução significativa no valor de maturação. Em adição, foi determinado o índice de Kuppermann aplicando questionário antes, durante e após o tratamento. Houve um decréscimo dos sintomas da menopausa, especialmente nas ondas de calor, $44 \%$ das mulheres que usaram isoflavona não relataram mais este sintoma, fato que ocorreu em apenas $10 \%$ das mulheres do grupo placebo (NAHAS et al., 2004).

Em geral, as lâminas de colpocitologia, são contadas 200 a 400 campos por lâmina, por um único colpocitologista em todo estudo e uma divergência na contagem é esperado, seja pela caracterização do limite entre células superficiais, intermediárias, parabasais, seja pelos critérios de restrição, tais como esfregaços 
dessecados, espessos, distendidios e paucicelulares. Foram encontrados, no presente estudo, 22 critérios de restrição em lâminas do grupo placebo antes do início do tratamento e 19 após o mesmo. De forma semelhante, foram detectadas 30 lâminas com critérios de restrição antes e 11 após o tratamento com isoflavona. Propôs-se, então, com o objetivo de diminuir a divergências nos resultados, a revisão das lâminas por escrutinadores, especialmente, porque a leitura de lâminas obtidas de mulheres na menopausa é de difícil análise por suas características de atrofia do epitélio, do "ressecamento" natural da vagina, da friabilidade com conseqüente facilidade de sangramento, da ausência fisiológica da lubrificação natural e da presença freqüente de muco espesso.

Apesar da qualidade dos esfregaços não ter sido totalmente satisfatória e das possíveis divergências encontradas, no presente estudo, ficou claro que o uso de isoflavona por 24 semanas, diminui a porcentagem de células parabasais e aumenta a porcentagem de células superficiais, sem alterar as células intermediárias, o que indica superficialização do epitélio pluriestratificado não ceratinizado da vagina, indicando efeito estrogênico da isoflavona neste epitélio. Além disso, esses dados foram confirmados através da análise do Índice de Picnose, de Eosinofilia e Valor de maturação. Houve pequena variação entre os três métodos de coleta, sem, no entanto, alterar a interpretação dos resultados, sendo o urocitograma o método de coleta mais sensível.

\subsection{Microbiota vaginal}

No presente estudo, encontrou-se diminuição significativa do número de células epiteliais $(P=0,005)$ e aumento significativo nos Bacilos de Döederlein $(P=0,005)$. Estes resultados não foram observados no grupo placebo. Esta avaliação foi feita com base nos estudos de Nugent et al. (1991) e Anukam et al. (2006) para a contagem dos elementos celulares e dos morfotipos bacterianos em lâminas coradas pelo método de Gram modificado.

Os agentes bacterianos foram detectados pelas lâminas de colpocitologia e bacterioscopia, pelo exame direto a fresco, das secreções vaginais. O grande 
número de agentes microbiológicos encontrados nas mulheres do presente estudo antes do tratamento podem ter dificultado a observação do efeito da isoflavona sobre o epitélio vaginal, visto que o estudo foi feito num tempo relativamente curto (24 semanas). Neste aspecto, é importante enfocar que se as pacientes, uma vez detectada a inflamação fossem primeiramente tratadas para posterior inclusão no estudo poderíamos ter tido melhores parâmetros para avaliação. A medida do pH vaginal de todas as mulheres, também teria sido útil para confirmar os casos de vaginose bacteriana e facilitar a análise dos resultados.

O índice de Nugent, obtido pela contagem dos morfotipos bacterianos em imersão, fornece números que permite a classificação em relação à vaginose bacteriana. Antes do início do tratamento com isoflavona 46,2\% das mulheres apresentavam vaginose, $19,2 \%$ colonização intermediária e 34,6\% vagina normal, essas porcentagens foram alterados no término do tratamento, no qual houve aumento das mulheres com vagina normal para 50,0\% e diminuição de vaginose bacteriana para 26,9\%, sem grandes alterações na porcentagem de mulheres com colonização intermediária. Nenhuma alteração significativa ocorreu na microbiota das pacientes que receberam tratamento com placebo. Se fosse refeito o desenho do presente estudo, uma atenção seria dada às questões preventivas de DST, como uso de preservativos femininos e masculinos (inclusão dos lubrificantes íntimos, devido ao ressecamento vaginal), confiança nos parceiros sexuais, conforme estudo de Rodrigues (1998).

Burton; Reid (2002) refere um grande número de casos de vaginose bacteriana em mulheres assintomáticas na pós-menopausa como conseqüência do empobrecimento da flora de Bacilos de Döederlein, devido ao hipoestrogenismo. Os resultados obtidos neste trabalho corroboram com a indicação terapêutica do uso de isoflavona para a melhoria na microbiota vaginal, visto as alterações observadas no índice de Nugent. Uma vez que o efeito estrogênico das isoflavonas favoreram o aumento dos Bacilos de Döederlein, fato realmente observado, que culminou com a diminuição do número de mulheres com vaginose.

Neste estudo foi detectada candidíase no grupo placebo antes do tratamento em 11 mulheres no exame direto a fresco, em 4 mulheres na colpocitologia, em 4 mulheres 
no sedimento urinário e em 1 mulher na bacterioscopia; depois do tratamento foi encontrada em 6 mulheres no exame direto a fresco e em 2 mulheres no sedimento urinário. No grupo tratado com isoflavona, antes do tratamento encontrou-se leveduras em 12 mulheres no exame direto a fresco, 10 mulheres na colpocitologia, 3 no sedimento urinário e 2 na bacterioscoscopia; após o tratamento encontrou-se levedura em 5 mulheres no exame direto a fresco, 5 na colpocitologia, 1 no sedimento urinário e 1 na bacterioscopia. O melhor teste para encontro de leveduras foi o exame direto a fresco, seguido pela colpocitologia, especialmente porque durante a citologia hormonal examinou-se as lâminas coradas pelo Shorrr, com lentes de imersão. Sugere-se, então, a prática de examinar pelo menos 20 campos no maior aumento, com imersão, após percorrer toda lâmina de colpocitologia no aumento preconizado. Os dados obtidos revelaram-se insuficientes para avaliar o efeito da isoflavona sobre a flora oportunista.

No estudo realizado no Pará com 1047 mulheres, 27\% delas com mais de 50 anos, apresentaram apenas flora bacilar, 42\% apresentaram 1 agente inflamatório, 26\% apresentaram 2\% de agentes inflamatórios, 4\% apresentaram 3 agentes e 1\% apresentou 4 agentes (RODRIGUES, 2001).

Nas mulheres do presente estudo, antes do uso da isoflavona, 16\% apresentaram flora bacilar inflamatórios, 4\% apresentaram 1 agente inflamatório, 34\% apresentaram 2 agentes inflamatórios, 27\% apresentaram 3 agentes inflamatórios e 19,5\% apresentaram 4 agentes inflamatórios. Após o uso da isoflavona $30 \%$ das mulheres apresentaram apenas flora bacilar, 15\% apresentaram 1 agente inflamatório, 23\% apresentaram 2 agentes inflamatórios, 27\% apresentaram 3 agentes inflamatórios e $4 \%$ apresentaram 4 agentes inflamatórios. Os dados encontrados nas mulheres do grupo placebo foram semelhantes aos encontrados no grupo tratado, demonstrando que a isoflavona não exerce, por si, efeito sobre a microbiota vaginal.

\subsection{Exame colpocitológico}

Os resultados da citologia oncótica são preliminares e não foi feita a releitura das 
lâminas colpocitológicas por outros escrutinadores no presente estudo. Observou-se o predomínio de esfregaços inflamatórios antes e após o tratamento com isoflavona ou placebo. Encontrou-se um caso de HSIL confirmado pelo resultado da citologia constante do prontuário medico do Posto de Saúde, da referida paciente, e um caso de AGUS no grupo placebo antes e após o tratamento. No grupo tratado com isoflavona, encontrou-se um caso de AGUSr que só foi observado após o tratamento.

Esfregaços atróficos de mulheres menopausadas podem apresentar problemas de interpretação e, freqüentemente, são dessecados e inflamados. Células atípicas parabasais mimetizam células de HSIL, ou células isoladas, atípicas coradas em laranja, podem simular malignidade e grupamentos de células parabasais podem parecer células endometriais. Se os esfregaços são coletados após tratamento com aplicação tópica de creme vaginal contendo estrógeno, após vários dias, resultará em esfregaço (limpo) com numerosas células características da atividade estrogênica. Se houver realmente lesões de baixo ou alto grau, as alterações não desaparecerão com o uso local do estrógeno (ATKINSON, 1992).

Além disso, ocorrem modificações celulares nos processos infecciosos, com aumento da esfoliação de células de camadas mais profundas. A leitura dos esfregaços de mulheres menopausadas merecem cuidados especiais para evitar falsos negativos ou falsos positivos, uma vez que é comum encontrar células parabasais com sinais de degeneração celular. Picnose, halos perinucleares, cariorrexis, cariopicnose, núcleos volumosos, núcleos opacos, marginalização/adensamento da cromatina e reparo celular (metaplasia) nem sempre relacionados a processos infecciosos são encontrados e o epitélio de reparo pode apresentar macronucléolos, cromatina grosseira e aumento da relação núcleo/citoplasma (GUPTA, 1991).

Thomas et al. (2003) citam que a citomorfologia cervical pode auxiliar o clínico no acompanhamento das pacientes na pós-menopausa, monitorando a reposição hormonal, através das modificações que as células sofrem com o hormônio, além da investigação para pré-malignidade/malignidade e agentes patogênicos. A coleta, o preparo e a fixação dos esfregaços citológicos das mulheres menopausadas 
necessita de atenção especial para não levar a erros nos resultados (RUBA et al., 2004).

Um fator de risco para o câncer de colo de útero é o início de atividade sexual precoce. No norte do Brasil, numa comunidade, 58 a $62 \%$ das mulheres com 17 anos já haviam iniciado atividade sexual sendo também precoce a paridade, pois $33 \%$ das crianças da comunidade estudada anteriormente nascem de mães com menos de 18 anos (RODRIGUES, 1999; RODRIGUES, 2000). Nas mulheres do presente estudo, apenas 10\% iniciaram atividade sexual antes dos 17 anos.

O encontro de alterações citopáticas sugestivas de HPV merece atenção especial visto que não se sabe o sorotipo do HPV, oncogênicoi, ou não, por isso há necessidade de esclarecimento por técnicas de biologia molecular para o diagnóstico . De um total de 4500 lâminas, o uso de critérios presuntivos para a sugestão da presença do HPV, anfofilia, binucleação, núcleos rugosos, disceratose, placas de células disceratóticas e coilocitose, levou ao encontro de 120 casos de coilocitose e 27 casos de critérios presuntivos de HPV na colpocitologia tendo sido, todos eles, por laudo histológico (DELBIN et al., 1993; RODRIGUES \& ASSUNÇÂO, 1995). No presente estudo foi sugerido a presença do HPV em $21,1 \%$ das mulheres do grupo placebo antes e $13 \%$ das mulheres do grupo placebo após o tratamento. Nas mulheres do grupo tratado por isoflavona antes do tratamento encontrou-se alterações citopáticas sugestivas de HPV em 27\% e 11,1\% após o tratamento.

Como a transformação intraepitelial é progressiva e pode evoluir num período de 1020 anos para chegar a uma lesão cancerosa invasiva, o pico de ocorrência dessas lesões acontece dos 40 aos 60 anos (MANUAL TÉCNICO DE PREVENÇÃO DO CÃNCER DO COLO DO ÚTERO, MS-2002). Este período coincide com o início da menopausa e, conforme citado acima, nesta época da vida da mulher, várias alterações do epitélio vaginal podem dificultar a coleta de material para exame, bem como levar a falsos diagnósticos. A própria condição da paciente sem reposição hormonal no início da pesquisa já traz complicações quanto à obtenção de uma lâmina de acordo com os critérios estabelecidos por Bethesda. 
Entretanto, após o tratamento com isoflavona ou com placebo observou-se melhor aspecto destes esfregaços. Os critérios de qualidade avaliados foram esfregaços dessecados, distendidos, espessos e paucicelulares. A melhora da qualidade foi maior no grupo tratado com isoflavona, no qual houve $58,6 \%$ de redução dos critérios de restrição da qualidade, enquanto no grupo placebo a melhora dos esfregaços foi de apenas $17,4 \%$.

As campanhas de prevenção de DST/AIDS não se mostram efetivas, uma vez que, até nas pessoas que possuem informação sobre o assunto, não se observa nenhum impacto sobre o comportamento. No presente estudo não foi realizado nenhum trabalho educacional quanto à questão das DST, no entanto, fica a sugestão de campanhas específicas para as mulheres menopausadas, não só porque várias delas deveriam ser testadas para HIV (conforme Ministério da Saúde, todas as mulheres que apresentem mais que 3 agentes inflamatórios devem ser fazer este exame).

Num estudo que envolveu prevenção de DST/AIDS e PCCU (Programa do Câncer do Colo do Útero), em Parauapebas, Carajás, no Pará, em 1997, 20\% das mulheres responderam que quando o parceiro sexual queria usar preservativo, elas não aceitavam, apenas $11 \%$ delas responderam que o casal usava preservativo, 15\% responderam que o casal nunca havia conversado sobre o assunto e $31 \%$ delas respondeu que nenhum dos dois aceitava o preservativo. Dois anos depois, em 1999, apenas 3,4\% das mulheres não aceitavam o preservativo quando o parceiro queria usar, 26,8\% das mulheres revelou que o casal concordava com o uso do preservativo, apenas $3 \%$ dos casais nunca tinham falado sobre o assunto e $22,8 \%$ dos casais nenhum dos dois aceitava o preservativo. Apesar da diferença encontrada nos relatos das mulheres após os dois anos, não deve ter diminuído o número de práticas de risco, já que não houve diminuição na freqüência das DST nos exames (RODRIGUES, 1999). Até comunidades indígenas, aparentemente isoladas, como os Parakanã, no Pará têm resultados assustadores como encontraram Brito et al. (1996), no qual 63,4\% das mulheres apresentaram Gardnerella e $23,2 \%$ de alterações citopatológicas compatíveis com a presença de HPV. 
No presente estudo, apesar de não ter sido dado a merecida atenção à prevenção de DSTs, afloram alguns dados interessantes. Das mulheres que faziam parte do grupo placebo, 39\% das mulheres fizeram cauterização; 4,3\% referem exames histopatológicos anteriores, como por exemplo, o relato de diagnóstico de HPV há 38 anos pela mulher que apresentou diagnóstico de HSIL no colpocitológico. No grupo tratado com isoflavona, $34,6 \%$ das pacientes relataram ter feito cauterização e $19,2 \%$ referem exames histopatológicos anteriores dos quais desconhecemos os resultados. A média de parceiros das mulheres no grupo placebo foi de 1,48 e no grupo tratado com isoflavona foi 1,57 parceiros. Com relação ao uso de anticoncepção oral no grupo placebo foi de $43,47 \%$ e no grupo tratado por isoflavona foi 46,155 das mulheres.

\subsection{Sinais e sintomas da menopausa}

A terapia combinada de estrogênio com progesterona sintéticos é muito usada para controlar os sinais e sintomas de atrofia vaginal (MARX et al., 2004). Tan et al. (2005) avaliaram o efeito de estrogênio/progesterona nos sintomas vasomotores e na atrofia vaginal, em mulheres de diferentes etnias, tendo sido observada uma melhoria dos sintomas. No entanto, apesar de conhecidos os efeitos benéficos da reposição hormonal estroprogestiva reduzindo os sintomas vasomotores, tratando a atrofia vaginal e prevenindo a osteoporose, cerca de 70\% das mulheres desistem do tratamento devido a sangramentos, mastalgia, náuseas, enxaqueca, ganho de peso, retenção hídrica e do medo de aumentar a probabilidade de adquirir câncer de mama, sendo estas pacientes aquelas necessitam de uma teraía alternativa, podendo optar pelo tratamento com fitoestrógenos (ALBERTAZZI, 1998).

No presente estudo, avaliou-se o efeito da isoflavona sobre as queixas clínicas das pacientes, divididas em sintomas agrupados e comparou-se com o grupo placebo. Os sinais e sintomas antes do tratamento com placebo ou isoflavona foram semelhantes, não havendo variação no início do estudo. Eles foram agrupados em sintomas vasomotores $(P=0,18)$, somáticos $(P=0,31)$, psicossomáticos $(P=0,13)$ e urogenitais $(P=0,33)$. 
Os sintomas vasomotores (ondas de calor, sudorese e palpitação) diminuíram significativamente apenas no grupo tratado com isoflavona $(P=0,03)$. Em relação às sintomas somáticos (zumbido, tonturas, mialgia, artralgia, neuralgia, dor lombar, dor no baixo ventre, flacidez, pele do corpo e formigamento) houve diminuição no grupo placebo $(P=0,004)$ e também do grupo tratado $(P<0,0001)$, resposta semelhante foi observada nos sintomas psicossomáticos (irritabilidade, ansiedade, depressão, amnésia, diminuição da libido, cefaléia, fadiga mental, insônia e melancolia) no qual houve diminuição das queixas no grupo placebo $(0,0003)$ e no grupo tratado com isoflavona $(P<0,0001)$. Embora a diminuição das queixas tenham sido significativas tanto no grupo placebo como no grupo tratado com isoflavona, para os sintomas somáticos e psicossomáticos, está claro que a diminuição foi maior nas mulheres que receberam isoflavona. As queixas urogenitais (dispareunia, incontinência urinária, dor miccional, ressecamento vaginal e sinusorragia) também foram analisadas e observou-se diminuição estatisticamente significativa no grupo placebo $(P=0,05)$ e no grupo tratado $(P=0,04)$.

O índice de Kuppermann é um dos instrumentos mais usados para avaliação clínica dos sintomas da menopausa (KUPPERMANN, 1953). No presente estudo, observou-se diminuição significativa deste índice tanto no grupo placebo $(P=0,016)$ como no grupo que recebeu isoflavona $(P=0,0002)$. De forma semelhante aos resultados anteriores, no qual houve diminuição dos sintomas nos dois grupos, a diferença foi mais expressiva nas mulheres tratadas com isoflavona.

Comparando mulheres tratadas com isoflavona e placebo, usando o índice de Kuppermann, Nahas et al. (2004) encontraram diminuição nas ondas de calor no grupo tratado com isoflavona. Kaari et al. (2006) comparando estrógeno conjugado com altas doses de isoflavona, conseguiram diminuir os sintomas de ondas de calor em ambos os grupos.

Alder (1988) critica alguns pontos do índice de Kupperman, uma vez que nos anos 50 a estatística e a psicologia ainda não eram aplicadas como nos dias de hoje e, também, a relação médico x paciente não era satisfatória e os sintomas pesquisados através deste índice não levava em conta a sexualidade, o contexto social e as diferenças das queixas da menopausa nos diferentes grupos étnicos. O peso maior 
conferido, no índice de Kuppermann, aos sintomas vasomotores, nervosismo, insônia e parestesia não correspondem aos sintomas valorizados pelas mulheres atualmente. As diferenças entre a época de criação do índice de Kuppermann para os dias atuais, principalmente em relação à valorização dos sintomas e o modo de encarar a menopausa, levam a um questionamento sobre o real peso dado aos sintomas neste índice. Apesar disso, a aplicação dos questionários de queixas clínicas para a obtenção do índice de Kuppermann possibilita que a mulher tenha maior atenção sobre suas próprias queixas, sua condição feminina e a possibilidade de melhoria na sua qualidade de vida.

Em relação aos sinais e sintomas, claramente houve diminuição das queixas clínicas nas mulheres tratadas com isoflavona, mas mulheres que receberam placebo também apresentaram melhora neste parâmetro. Este resultado apresentado no grupo placebo também foi observado nos trabalhos apresentado a literatura (NAHAS, et al., 2004). O efeito placebo está ligado ao efeito psicológico da crença de estar tomando um medicamento (estudo duplo cego). Da mesma forma que mulheres do grupo isoflavona acreditavam estar recebendo placebo e embora não tivéssemos esta medida, elas realmente melhoraram menos do que as mulheres que confiavam nos efeitos benéficos da isoflavona. Para investigar o motivo da melhora neste grupo de mulheres, seria necessário realizar um estudo mais detalhado sobre sinais e sintomas que contasse com a participação de uma equipe multiprofissional.

A menopausa é uma fase complicada da vida da mulher, na qual muitas questões emocionais e afetivas estão envolvidas, os sintomas são subjetivos e dependem do relato da paciente, que nem sempre consegue expressar de forma clara suas angústias, medos, inseguranças ou mesmo aquelas alterações que são questionadas diretamente.

Com base em todas as alterações observadas na pré e pós-menopausa e, principalmente, o envelhecimento da população, sendo cada vez maior o número de mulheres que atravessam este período, é importante a condução de estudos que busquem alternativas de tratamento, uma vez que os atualmente existentes são questionados quanto à segurança. Além disso, é importante estudar a menopausa 
não como uma doença, uma vez que é um processo fisiológico inevitável a partir de certa idade, mas sim, como um período da vida da mulher no qual esta necessita de acompanhamento adequado e de tratamentos para aliviar os sinais e sintomas, sem causar risco a sua saúde. O presente estudo demonstrou de forma clara, que a isoflavona causa benefícios nas mulheres menopausadas, no entanto, é necessário a condução de vários estudos investigando melhor seus efeitos e principalmente sua segurança.

Relatamos também aqui um outro estudo, do nosso grupo de pesquisa do qual participaram as mesmas pacientes, enfocando os efeitos das isoflavonas sobre o sistema de coagulação - fibrinólise e perfil lipídico de mulheres em pós-menopausa, antes e após o tratamento com $40 \mathrm{mg} / \mathrm{dia}$ de isoflavona e $40 \mathrm{mg} / \mathrm{dia}$ de caseína, durante 24 semanas. Os resultados apontaram que não houve ativação da coagulação sanguínea, após o uso de isoflavona, devido à ausência de alteração significativa da atividade dos fatores VII e X e pela ausência de alteração significativa dos níveis de fibrinogênio. Não se observou, ainda, alteração estatisticamente significativa no perfil lipídico destas pacientes, mas houve um aumento significativo nos níveis de HDL, que não apresentou diferença significativa no grupo placebo para este parâmetro. De forma semelhante, o tratamento com isoflavona não alterou os níveis de estradiol e os níveis de FSH.

A determinação dos níveis urinários da daidzeína e genisteína, metabólitos da soja, feito anteriormente usando a urina das mesmas mulheres avaliadas neste projeto, nos permitiu avaliar a adesão das pacientes ao tratamento como também se a fonte exógena de soja, pela alimentação, pode estar interferindo nos nossos resultados. Houve aumento da eliminação urinária de daidzeína $(P=0,0193)$ e genisteína $(P=0,0483)$ nas mulheres que receberam isoflavona e o mesmo não foi observado nas mulheres do grupo placebo. Esses dados mostram que houve adesão ao tratamento e que o consumo de soja na dieta diária não interferiu na concentração urinária destes metabólitos. 


\section{CONCLUSÃO}

Os resultados obtidos no presente estudo permitem concluir que:

O tratamento com isoflavona:

- Exerce efeito estrogênico sobre o epitélio vaginal;

- Melhora a biocenose vaginal, aumentando o número de latobacilos;

- Apresenta efeito protetor sobre o epitélio vaginal, fazendo-o menos susceptível aos agentes inflamatórios;

- Melhoras significativamente os sintomas psicossomáticos, somáticos, vasomotor e urogenitais da menopausa.

No grupo placebo:

- Não exerce efeito estrogênico sobre o epitélio;

- Não houve melhora da biocenose;

- Não apresentou efeito protetor sobre o epitélio vaginal;

- Não houve melhora dos sintomas vasomotores da menopausa, porém melhorou os sintomas somáticos, psicossomáticos e urogenitais, porém de forma menos significativa que no grupo tratado com isoflavona. 


\section{REFERÊNCIAS BIBLIOGRÁFICAS}

AGÊNCIA NACIONAL DE VIGILÂNCIA SANITÁRIA (ANVISA). Isoflavona. Disponível em: http://www.anvisa.gov.br/farmacovigilancia/informes/2002/informe_5.htm. Acesso em dez. 2006.

AL-AZAAWI, F. The menopause and its treatment in perspective. Postgrad. Med. J., London, v. 77, n. 907, p. 292 - 304, may. 2001.

ALBERT, A.; ALTABRE, C.; BARÓ, F.; BUENDÍA, E.; CABERO, A.; CANCELO, M.J.; CASTELO-BRANCO, C.; CHANTRE, P.; DURAN, M.; HAYA, J.; IMBERT, P.; JULIÁ, D.; LANCHARES, J.L.; LLANEZA, P.; MANUBENS, M.; MINÃNO, A.; QUEREDA, F.; RIBES, C.; VÁSQUEZ, F. Efficacy and safety of a phytoestrogen preparation derived from Glycine $\max (\mathrm{L}$.) Merr in climacteric symptomatology: a multicentric, open, prospective and non-randomized trial. Phytomedicine, Stuttgart, v. 9, n. 2, p. $85-92$, mar. 2002.

ALBERTAZZI, P.A.; FRANCESCO, P.; BONACCORSI, G.; ZANOTTI, L; FORINI, E.; ALOYSIO, D. The effect of dietary soy supplementation on hot flushes. Obstet. Gynecol., New York, v. 91, n. 1, p. 6 - 10, jan. 1998.

ALDER, E. The Blatt-Kupperman menopausal index: a critique. Maturitas, Amsterdam, v. 29, n. 1, p. 19 - 24, may 1998.

ALDRIGHI, J.M.; ALDRIGHI, C.M.S.; ALDRIGHI, A.P.S. Alterações sistêmicas do climatério. Rev. Bras. Méd., v. 59, 2002.

ALVES, D.L.; da SILVA, C.R. Fitohormônios - abordagem natural da terapia hormonal. São Paulo: Editora Atheneu, 2003.

ANUKAM, K.C.; OSAZUWA, E.O.; AHONKHAI, I.; REID, G. Lactobacillus vaginal microbiota of women attending a reproductive health care service in Benin City, Nigéria. Sex. Transm. Dis., Philadelphia, v. 33, n. 1, p. 59 - 62, jan. 2006.

ATKINSON, B.F. Atlas of diagnostic cytopathology. 1 ed. Phliladelphia: Saunders, 1992.

AVIS, N.E.; STELLATO, R.; CRAWFORD, S.; BROMBERGER, J.; GANZ, P.; CAIN, V.; KAGAWA-SINGER, M. Is there a menopausal syndrome? Menopausal status and symptoms across racial/ethnic groups. Soc. Sci. Med., Oxford, v. 52, n. 3, p. $345-$ 356, feb. 2001.

AYALA, M.J.; WILAPLANA, E.V.; ORTIZ, F.G.; FERNÁNDEZ, F.M.; Citopatologia Ginecológica. 2 ed. Barcelona: Editorial científico-médica, p. 151 - 178, 1985.

BAIRD, D.D.; UMBACH, D.M.; LANSDELL, L.; HUGHES, C.L.; SETCHELL, K.D.; WEINBERG, C.R.; HANEY, A.F.; WILCOX, A.J.; McLACHLAN, J.A. Dietary intervention study to assess estrogenicity of dietary soy among postmenopausal 
women. J. Clin. Endocrinol. Metab., Springfield, v. 80, n. 5, p. 1685 - 1690, may 1995.

BARNABEI, V.M.; GRADY, D.; STOVALL, D.W.; CAULEY, J.A.; LIN, F.; STUENKEL, C.A.; STEFANICK, M.L.; PICKAR, J.H. Menopausal symptoms in older women and the effect of treatment with hormone therapy. Obstet. Gynecol., New York, v. 100, n. 6, p. $1209-1218$, dec. 2002.

BARNES, B. Soy isoflavones - Phytoestrogens and what else? J. Nutr., Philadelphia, v. 134, n. 5, p. 1225S - 1228S, may. 2004.

BECK, V.; ROHR, U.; JUNGBAUER, A. Phytoestrogens derived from red clover: an alternative to estrogen replacement therapy? J. Steroid. Biochem. Mol. Biol., Oxford, v. 94, n. 5, p. $499-518$, apr. 2005.

BELINSON, J.L.; OIAO, Y.L.; PRETORIUS, R.G.; ZHANG, W.H.; RONG, S.D.; HUANG, M.N.; ZHAO, F.H.; WU, L.Y.; REN, S.D.; HUANG, R.D.; WASHINGTON, M.F.; PAN, Q.J., LI, J. FIFE, D. Shanxi Province cervical cancer screening study II: self-sampling for high-risk human papillomavirus compared to direct sampling for human papillomavirus and liquid based cervical cytology. Int. J. Gynecol. Cancer, Cambridge, v. 13, n. 6, p. 819-826, nov. dec. 2003.

BERRY, M.; METZGER, D.; CHAMBON, P. Role of the two activating domains of the oestrogen receptor in the cell-type and promoter-context dependent agonistic activity of the anti-oestrogen 4-hydroxytamoxifen. EMBO J., Eynsham v. 9, n. 9, p. 2811 2818, sep. 1990.

BEZERRA, H.L.; RIZZO, L.V.; YU, M.C.Z.; de FREITAS, D. Utilização da albumina na citologia esfoliativa em pacientes com conjuntivite alérgica. Arq. Bras. Oftalmol., São Paulo, v. 66, n. 6, p. 854 - 858, dez. 2003.

BOSCHANN, H.W. In which especial cases is it essential to express the cytologic report in indices? In: Symposium on Hormonal Cytology. Acta Cytologica, Chicago, v. 12, n. 2, p. $87-127,1968$.

BOSSEMEYER, A. Aspectos Gerais do Climatério. In: Fernandes, C.E.; Melo, N.R.; Wehba, S. Climatério Feminino: fisiopatologia, diagnóstico e tratamento. São Paulo: Lemos Editorial, 1999.

BLATT, M.H.G.; WIESBADER, H.; KUPPERMAN, H.S. Vitamin E and climacteric syndrome. AMA Arch. Intern. Med., Chicago, v. 91, n. 6, p. 792 - 799, jun. 1953.

BRITISH HEART FOUNDATION. European cardiovascular disease statistics . 2000 ed.

BRITO, E.B.; MENEZES, R.C.; MARTINS, S.J.; BASTOS, M.G.; SOUZA, A. Preliminary study on low-trait infection and cervical epithelial displasia in women from the Parakanã tribe South America. Rev. Assoc. Med. Bras., São Paulo, v. 42, n. 01, p. 11 - 15, jan. - mar. 1996. 
BURK, R.D. Human papillomavirus and the risk of cervical cancer. Hosp. Pract. (Minneap.), Minneapolis, v. 34, n. 12, p. 103 - 111, nov. 1999.

BURTON, J.P.; REID, G. Evaluation of the bacterial vaginal flora of 20 postmenopausal women by direct (Nugent score) and molecular (polymerase chain reaction and denaturing gradient gel electrophoresis) techniques. J. Infect. Dis., Chicago, v. 186, n. 12, p. 1770 - 1780, dec, 2002.

CARVALHO, G. Citologia do Trato Genital Feminino. 3 ed. São Paulo: Atheneu, 1993.

CHIECHI, L.M.; PUTIGNANO, G. ; GUERRA, V. ; SCHIAVELLI, M.P. ; CISTERNINO, A.M. ; CARRIERO, C. The effect of a soy rich diet on the vaginal epithelium in postmenopause: a randomized double blind trial. Maturitas, Amsterdam, v. 45, n. 4, p. 241 - 246, aug. 2003.

CHRISTIANSEN, C. Hormone replacement therapy for the postmenopausal woman. Maturitas, Amsterdam, v. 38, suppl. 1, s. 1 -2, jun. 2001.

CLARKSON, T.B.; ANTHONY, M.S.; MORGAN, T.M. Inhibition of postmenopausal atherosclerosis progression: a comparison of the effects of conjugated equine estrogens and soy phytoestrogens. J. Clin. Endocrinol. Metab., Springfield, v. 86, n. 1 , p. $41-47$, jan. 2001.

CLINE, J.M.; PASCHOLD, J.C.; ANTHONY, M.S.; OBASANJO, I.O.; ADAMS, D.V.M. Effects of hormonal therapies and dietary soy phytoestrogens on vaginal cytology in surgically postmenopausal macaques. Fertil. Steril., New York, v. 65, n. 5, p. 1031 1035, may 1996.

CODECIDO, E.F. Consideraciones sobre la tecnica del urocitograma. Rev.Obstet. Ginecol. Venez., Caracas, v. 21, p. 69 - 78, 1961.

CORDEIRO, M.R.A.; COSTA, H.L.F.F.; ANDRADE, R.P.; BRANDÃO, V.R.A.; SANTANA, R. Inspeção visual do colo uterino após aplicação de ácido acético no rastreamento das neoplasias intraepiteliais e lesões induzidas por HPV. Rev. Bras. Ginecol. Obstet., Rio de Janeiro, v. 27, n. 2, p. 51 - 57, fev. 2005.

CURRAN, D.R.; STIGLEMAN, S. Should we discontinue Pap smear screening in women aged > 65 years? J. Fam. Pract., New York, v. 53, n. 4, p. 308 - 310, apr. 2004.

DELBIN, A.L.; NOMURA, Y.M.; RODRIGUES, E.T. Prevenção do câncer ginecológico - busca ativa de DST. In: Anais do $45^{\circ}$ CONGRESSO BRASILEIRO DE GINECOLOGIA E OBSTETRÍCIA, 1993, Salvador.

De LORENZI, D.R.S. ; DANELON, C. ; SACILOTO, B. ; PADILHA Jr., I. Fatores indicadores da sintomatologia climatérica. Rev. Bras. Ginecol. Obstet., Rio de Janeiro, v. 27, n. 1, p. 12 - 19, jan. 2005. 
DONDERS, G.G.G.; VEREECKEN, A.; DEKEERSMAECKER, A.; BULCK, B.V.; SPITZ, B. Wet mount microscopy reflects functional vaginal lactobacillary flora better than Gram staim. J. Clin. Pathol., London, v. 53, n. 4, p. 308 - 313, apr. 2000.

DUNCAN, A.M.; UNDERHILL, K.E.W.; XU, X.; LAVALLEUR, J.; PHIPPS, W.R.; KURZER, M.S. Modest hormonal effects of soy isoflavones in postmenopausal women. J. Clin. Endocrinol. Metab., Springfield, v. 84, n. 10, p. 3479 - 3484, oct. 1999.

EWERTZ, M.; MELLEMKJAER, L.; POULSEN, A.H.; FRIIS, S.; SORENSEN, H.T.; PEDERSEN, L.; MCLAUGHLIN, J.K.; OLSEN, J.H. Hormone use for menopausal symptoms and risk of breast cancer. A Danish cohort study. Br. J. Cancer , London, v. 92, n. 7, p. 1293 - 1297, apr. 2005.

FERIM, J. Does Finding indentical indices in two women indicate that similar endocrinologic conditions exist? In: Symposium on Hormonal Cytology. Acta Cytologica, Chicago, v. 12, n. 2, p. $87-127,1968$.

FERNANDES, A.M.S.; LEME, L.C.P.; YAMADA, E.M.; SOLLERO, C.A. Avaliação do índice de massa corpórea em mulheres atendidas em ambulatório geral de ginecologia. Rev. Bras. Ginecol. Obstet., Rio de Janeiro, v. 27, n. 2, p. $69-74$, fev. 2005.

FRANKOVICH, R.J.; LEBRUN, C.M. Menstrual cycle, contraception, and performance. Clin. Sports Med., Philadelphia, v. 19, n. 2, p. 251-271, apr. 2000.

GALLO, D.; CANTELMO, F.; DISTEFANO, M.; FERLINI, C.; ZANNONI, G.F.; RIVA, A.; MORAZZONI, P.; BOMBARDELLI, E.; MANCUSO, S.; SCAMBIA, G. Reproductive effects of dietary soy in female wistar rats. Food. Chem. Toxicol., Oxford, v. 37, n. 5, p. 493-502, may 1999.

GENAZZANI, A.R.; GAMBACCIANI, M.; INTERNATIONAL MENOPAUSE SOCIETY. Controversial issues in climacteric medicine I. Cardiovascular disease and hormone replacement therapy. International Menopause Society Expert Workshop. 13-16 October 2000, royal society of medicine, London, UK. Climacteric., New York, v. 3, n. 4 , p. $233-240$, dec. 2000.

GENAZZANI, A.R.; GAMBACCIANI, M. HRT in the thrid millenium. Maturitas, Amsterdam, v 38, suppl. 1, s. 49 -55, jun. 2001.

GIACOBINI, E. Aging, Alzheimer's disease, and estrogen therapy. Exp. Gerontol., Oxford, v. 33, n. 7 - 8, p. 865 869, nov-dec. 1998.

GUPTA, P.K. Microbiology, inflammation and viral infections. In: BIBBO, M. Hormonal Cytology. Comprehensive cytopathology. 1 ed., Philadelphia: W. B. Saunders Company, p. 85 - 114, 1991.

GUYTON, A.C.; HALL, J.E. Fundamentos de Guyton - Tratado de Fisiologia Médica. 10 ed. Rio de Janeiro: Guanabara Koogan, 2002, cap. 81. 
HAN, K.K.; SOARES Jr, J.M.; HAIDAR, M.A.; de LIMA, G.R.; BARACAT, E.C. Benefits of soy isoflavone therapeutic regimen on menopausal symptoms. Obstet. Gynecol., New York, v. 99, n. 3, p. 389 - 394, mar. 2002.

HERRINGTON, D.M.; REBOUSSIN, D.M.; BROSNIHAN, K.B.; SHARP, P.C.; SHUMAKER, S.A.; SNYDER, T.E.; FURBERG, C.D.; KOWALCHUK, G.J.; STUCKEY, T.D.; ROGERS, W.J.; GIVENS, D.H.; WATERS, D. Effects of estrogen replacement on the progression of coronary-artery atherosclerosis. N. Engl. J. Med., Boston, v. 343, n. 8, p. 522 - 529, aug. 2000.

HILLIER, S.L.; LAU, R.J. Vaginal microflora in postmenopausal women who have not received estrogen replacement therapy. Clin. Infect. Dis., Chicago, Suppl. 2:S123126, sep. 1997.

HPV - Diagnóstico e manejo clínico da infecção pelo Papilomavírus humano - MS CN - DST e AIDS, 2003.

HULLEY, S.; GRADY, D.; BUSH, T.; FURBERG, C.; HERRINGTON, D.; RIGGS, B.; VITTINGHOFF, E. Randomized trial of estrogen plus progestin for secondary prevention of coronary heart disease in postmenopausal women. Heart and Estrogen/progestin Replacement Study (HERS) Research Group. JAMA, Chicago, v. 280, n. 7, p. 605 - 613, aug. 1998.

HUSAIN, O.A.N.; BUTLER, E.B. Atlas Colorido de Citologia Ginecológica. São Paulo: Artes Médicas, 1992.

HUSTIN, J.; Van Den EYNDE, J.P. Cytologic evaluation of the effect of various estrogens given in postmenopause. Acta. Cytol., Chicago, v. 21, n. 2, p. $225-228$, mar-apr. 1977.

KAARI, C.; HAIDAR, M.A.; JUNIOR, J.M.; NUNES, M.G.; QUADROS, L.G.; KEMP, C.; STAVALE, J.N.; BARACAT, E.C. Randomized clinical trial comparing conjugated equine estrogens and isoflavone in postmenopausal women: a pilot study. Maturitas, Amsterdam, v. 53, n. 1, p. 49 - 58, jan. 2006.

KUIPER, G.G.; LEMMEN, J.G.; CARLSSON, B.; CORTON, J.C.; SAFE, S.H. van der SAAG, P.T. van der BURG, B.; GUSTAFSSON, J.A. Interaction of estrogenic chemical and phytoestrogens with estrogen receptor $\beta$. Endocrinology, Springfield, v. 139, n. 10, p. 4252 - 4263, oct, 1998.

KUPPERMANN, H.S.; BLATT, M.H.; WIESBADER, H.; FILLER, W. Comparative clinical evaluation of estrogenic preparations by the menopausal and amenorrheal indices. J. Clin. Endocrinol. Metab., Springfield, v. 13, n. 6, p. 688 - 703, jun. 1953.

LAHTI, E.; VUOPALA, S.; KAUPPILA, A.; BLANCO, G.; RUOKONEN, A.; LAATIKAINEN, T. Maturation of vaginal and endometrial epithelium in postmenopausal breast cancer patients receiving long-term tamoxifen. Gynecol. Oncol., New York, v. 55, n. 3, Pt. 1, p. 410 - 414, dec. 1994. 
LAWSON, H.W.; LEE, N.C.; HENSON, R.; MILLER, D.S. Cervical cancer screening among low-income women: results of a national screening program, 1991-1995. Obstet. Gynecol., New York, v. 92, n. 5, p. 745 - 752, nov. 1998.

LENCIONE, L.J.; GARCIA, C.G.; ALONSO, C.A. Efecto del estriol sobre el urocitograma, colpocitograma y cristalizacion del moco cervical. La Prensa Médica Argentina, Buenos Aires, v. 50, n. 3, p. 215 - 219, 1963.

LUSTOSA, A.B.; GIRÃO, M.J.B.C.; SARTORI, M.G.F.; BARACAT, E.C.; de LIMA, G.R. Citologia hormonal do trato urinário baixo e da vagina de mulheres na pósmenopausa, antes e durante estrogenioterapia oral e transdérmica. Rev. Bras. Ginecol. Obstet., Rio de Janeiro v. 24, n. 9, out. 2002.

MACHADO, L.V. Quão estrogênicos são os fitoestrogênios? Femina, Rio de Janeiro, v. 31, n. 9, p. $775-780$, out. 2003.

MANONAI, J.; CHITTACHOROESN, A.; THEPPISAI, U. Effect of estradiol valerate and levonogestrel on vaginal health. Eur. J. Obstet. Gynecol. Reprod. Biol., Amsterdam, v. 115, n. 2, p. 190 - 193, aug. 2004.

MANONAI, J.; SONGCHITSOMBOON, S.; CHANDA, K.; HONG, J.H.; KOMINDR, S. The effect of a soy-rich diet on urogenital atrophy: a randomized, cross-over trial. Maturitas, Amsterdam, v. 54, n. 2, p. 135 - 140, may. 2006.

MANUAL DE CONTROLE DAS DOENÇAS SEXUALMENTE TRANSMISSÍVEIS Ministério da Saúde, p. 80 - 112, 1999.

MANUAL TÉCNICO DE PREVENÇÃO DO CÂNCER DO COLO DO ÚTERO Ministério da Saúde, p. 7, 2002.

MARX, P.; SHADE, G.; WILBOURN, S.; BLANK, S.; MOYER, D.L.; NETT, R. Lowdose $(0.3 \mathrm{mg})$ synthetic conjugated estrogens $A$ is effective for managing atrophic vaginitis. Maturitas, Amsterdam, v. 47, n. 1, p. 47 - 54, jan. 2004.

MCMILLAN, T.L.; MARK, S. Complementary and alternative medicine and physical activity for menopausal symptoms. J. Am. Med. Womens Assoc., Nashville, v. 59, n. 4, p. $270-277,2004$.

McKEE, G. Citopatologia. 1 ed. São Paulo: Artes Médicas, 1997.

MEISELS, A. The maturation value. Acta Cytol., Chicago, v. 11, n. 4, p. 249, jul aug. 1967.

MILDE-LANGOSCH, K.; RIETHODORF, S.; LÔNING, T. Association of human papillomavirus infection with carcinoma of the cervix uteri and its precursor: theoretical and practical implications. Virchows Arch., Berlin, v. 437, n. 3, p. $227-$ 233, sep. 2000.

MOSCA, L.; COLLINS, P.; HERRINGTON, D.M.; MENDELSOHN, M.E.; PASTERNAK, R.C.; ROBERTSON, R.M.; SCHENCK-GUSTAFSSON, K.; SMITH Jr, 
S.C.; TAUBERT, K.A.; WENGER, N.K.; AMERICAN HEART ASSOCIATION. Hormone replacement therapy and cardiovascular disease: a statement for healthcare professionals from the American Heart Association. Circulation, Dallas, v. 104, n. 4, p. 499 - 503, jul. 2001.

MURPHY, P.A.; SONG, T.; BUSEMAN, G.; BARUA, K.; BEECHER, G.R.; TRAINER, D.; HOLDEN, J. Isoflavones in retail and institutional soy foods. J. Agric. Food Chem., Washington, v. 47, n. 7, p. 2697 - 2704, jul. 1999.

NAFTOLIN, F.; STANBURRY, M.G. Phytoestrogens: are they really estrogen mimics? Fertil.Steril., New York, V. 77, n. 1, p. 15 -17, jan. 2002.

NAHAS, E.P.; NETO, J.N.; De LUCA, L.; TRAIMAN, P.; PONTES, A.; DALBEN, I. Benefits of soy germ isoflavones in postmenopausal women with contraindication for conventional hormone replacement therapy. Maturitas, Amsterdam, v. 48, n. 4, p. $372-380$, aug. 2004.

NORTH AMERICAM MENOPAUSE SOCIETY (NAMS). Treatment of Menopause associated vasomotor symptoms: position statement of the North Americam Menopause Society. Menopause, New York, v. 11, n. 1, p. 11-33, 2004.

NATHORST-BÖÖS, J.; HAMMAR, M. Effect on sexual life - a comparison between tibolone and continous estradiol-norethisterone acetate regimen. Maturitas, Amsterdam, v. 26, p. 15 - 20, 1997.

NATIONAL CANCER INSTITUTE (NCI). Cancer Facts: Human Papillomavirus and cancer. Disponível em: http://www.cancer.gov/cancertopics/factsheet/Risk/HPV. Acesso em dez. 2006.

NEUGARTEN, B.L.; KRAINES, R.J. "Menopausal Symptoms" in women of various ages. Psychosom. Med., Baltimore, v. 27, p. 266 - 273, may-jun, 1965.

NIKANDER, E.; RUTANEN, E.M.; NIEMINEN, P.; WAHLSTROM, T.; YLIKORKALA, O.; TIITINEN, A. Lack of effect of isoflavonoids on the vagina and endometrium in postmenopausal women. Ferti. Steril., New York, v. 83, n. 1, p. 137 - 142, jan. 2005.

NILSSON, K.; RISBERG, B.; HEIMER, G. The vaginal epithelium in postmenopause - cytology, histology and $\mathrm{pH}$ as methods of assessment. Maturitas, Amsterdam, v. 21, n. 1, p. $51-56$, jan. 1995.

NUGENT, R.P.; KROHN, M.A.; HILLIER, S. Reliability of diagnosing bacterial vaginosis is improved by a standardized method of gram stain interpretation. J. Clin. Microbiol., Washington, v. 29, n. 2, p. 297 - 301, feb. 1991.

OLOFSSON, A.S.; COLLINS, A. Psychosocial factors, attitude to menopause and symptoms in Swedish perimenopausal women. Climacteric. New York, v. 3, n. 1, p. $33-42$, mar. 2000.

OSOSKI, A.L.; KENNELLY, E.J. Phytoestrogens: a review of the present state of research. Phytother. Res., London, v. 17, n. 8, p. 845 - 869, sep. 2003. 
PAGE, C.; CURTIS, M.; SUTTER, M.; WALKER, M. ; HOFFMAN, B. Farmacologia integrada. 2 ed. Barueri: Manole, 2004.

PAPANICOLAOU, G.M.; TRANT, H.F. The diagnostic value of vaginal smears in carcinoma of the uterius. Am. J. Obstet. Gynecol., New York, v. 42, p. $193-206$, 1941.

PINHO, A.A.; de MATTOS, M.C.F.I. Validade da citologia cervicovaginal na detecção de lesões pré-neoplásicas e neoplásicas de colo de útero. J. Bras. Patol. Méd. Lab., Rio de Janeiro, v. 38, n. 3, jul. 2002.

PUNDEL, J.P.; MOITZHEIM, P.; BECKIUS, C. The basal membrane of the squamous epithelium of the vagina and uterine cervix. Comparative histologic and histo chemical study. Gynecol. Obstet. (Paris), Paris, v. 66, n. 2, p. 125 - 143, apr may, 1967.

RASSI, C.M.; LIEBERHERR, M.; CHAUMAZ, G.; POINTILLART, A.; COURNOT, G. Down-regulation of osteoclast differentiation by daidzein via caspase 3. J. Bone Miner. Res., New York, v. 17, n. 4, p. 630 - 638, apr. 2002.

RODRIGUES, E.T.; ASSUNÇÃO, M.C.G.A. DST diagnosticadas em exames citológicos. In: Anais do XXII CONGRESSO BRASILEIRO DE ANÁLISES CLÍNICAS, 1995, Recife.

RODRIGUES, E.T. DST-Estudo casado de citologia oncótica, exame direto a fresco, bacterioscopia. In: XI CONGRESSO BRASILEIRO DE PATOLOGIA DO TRATO GENITAL INFERIOR E COLPOSCOPIA. 1998, Brasília.

RODRIGUES, E.T. DST/Câncer Ginecológico/Comportamentos de risco e prevenção em 1997/1998/1999. In: Anais do XII CONGRESSO LATINO-AMERICANO DE DOENÇAS SEXUALMENTE TRANSMISSÍVEIS e IV CONFERÊNCIA PANAMERICANA DE AIDS. 1999, Salvador.

RODRIGUES, E.T. DST/Câncer Ginecológico/Comportamento de risco em Parauapebas-PA. In: Fórum 2000, I FÓRUM e II CONFERÊNCIA DE COOPERAÇÃO TÉCNICA HORIZONTAL DA AMÉRICA LATINA e do CARIBE EM HIVIAIDS e DST. 2000, Rio de Janeiro.

RODRIGUES, E.T. STD/CANCER/RISK BEHAVIOR/ Prevention in parauperabasPará-Brasil. In: Anais do XIX INTERNATIONAL PAPILLOMAVÍRUS CONFERENCE. 2001, Florianópolis.

ROSEN, C.J.; KESSENICH, C.R. The pathophysiology and treatment of postmenopausal osteoporosis. An evidence-based approach to estrogen replacement therapy. Endocrinol. Metab. Clin. North. Am., Philadelphia, v. 26, v. 2, p. 295 - 311, jun. 1997.

RUBA, S.; SCHOOLLAND, M.; ALLPRESS, S.; STERRETT, G. Adenocarcinoma in situ of the uterine cervix: screening and diagnostic errors in Papanicolaou smears. Cancer, New York, v. 102, n. 5, p. 280 - 287, oct. 2004. 
SAMPAIO, H.A.C. Aspectos nutricionais relacionados ao ciclo ao ciclo menstrual. Rev. Nutr., Campinas, v. 15, n. 3, p. 309 - 317, set - dez. 2002.

SANKAR, A.; WESLEY, R.; THARA, S.; DHAKAD, N.; CHANDRALEKHA, B.; SEBASTIAN, P.; CHITHARATHARA, K.; PARKIN, D.M.; NAIR, M.K. Test characteristics of visual inspection with $4 \%$ acetic acid (VIA) and Lugol's iodine (VILI) in cervical cancer screening in Kerala, India. Int. J. Cancer, Genève, v. 106, n. 3, p. $404-408$, sep. 2003.

SANTELL, R.C.; CHANG, Y.C.; NAIR, M.G.; HELFERICH, W.G. Dietary genistein exerts estrogenic effects upon the uterus, mammary gland and the hypothalamic/pituitary axis in rats. J. Nutr., Philadelphia, v. 127, n. 2, p. $263-269$, feb. 1997.

SCHINDLER, A.E. Differential effects of progestins on hemostasis. Maturitas, Amsterdam, v. 46, suppl. 1, s. 31 - 37, dec. 2003.

SETCHELL, K.D.; BROWN, N.M.; LYDEKING-OLSEN, E. The clinical importance of the metabolite equal-a clue to the effectiveness of soy and its isoflavones. J. Nutr., Philadelphia, v. 132, n. 12, p. 3577 - 3584, dec. 2002.

SIMON, J.A.; LIN, F.; VITTINGHOFF, E.; BITTNER, V.; FOR THE HEART AND ESTROGEN-PROGESTIN REPLACEMENT STUDY (HERS) RESEARCH GROUP. The relation of postmenopausal hormone therapy to serum uric acid and the risk of coronary heart disease events: the Heart and Estrogen-Progestin Replacement Study (HERS). Ann. Epidemiol., New York, v. 16, n. 2, p. 138 - 145, jul. 2005.

SOLERTE, S.B.; FIORAVANTI, M.; RACCHI, M.; TRABUCCHI, M.; ZANETTI, O. ; GOVONI, S. Menopause and estrogen deficiency as a risk factor in dementing illness: hypothesis on the biological basis. Maturitas, Amsterdam, v. 31, n. 2, p. 95 101, jan. 1999.

SPEROFF, L. Efficacy and tolerability of a novel estradiol vaginal ring for relief of menopausal symptoms. Obstet. Gynecol., New York, v. 102, n. 4, p. 823 - 834, oct. 2003.

STUART, G.; TAYLOR, G.; BANCEJ, C.M.; BEAULAC, J.; COLGAN, T.; FRANCO, E.L.; KROPP, R.Y.; LOTOCKI, R.; MAI, V.; MCLACHLIN, C.M.; ONYSKO, J.; MARTIN, R.E.; ELIT, L.; GUIJON, F.; MANN, J.; OGILVIE, G.; ROMANOWSKI, B.; TROMP, M. SOCIETY OF GYNECOLOGIC ONCOLOGISTS OF CANADA; CERVICAL CANCER PREVENTION NETWORK OF CANADA; CANADIAN COORDINATING OFFICE FOR HEALTH TECHNOLOGY ASSESSMENT. Report of the 2003 pan-Canadian forum on cervical cancer prevention and control. J. Obstet. Gynaecol. Can., Toronto, v. 26, n. 11, p. 1004 - 1028, nov. 2004.

TAKAHASHI, M. Color atlas of cancer cytology. 3 ed. Igaku-Shoin Medical Publishers, 2000.

TAMIMI, R.M.; HANKINSON, S.E.; CHEN, W.Y.; ROSNER, B.; COLDITZ, G.A. Combined estrogen and testosterone use and risk of breast cancer in 
postmenopausal women. Arch. Intern. Med., Chicago, v. 166, n. 14, p. $1483-1489$, jul. 2006.

TAN, D.; HAINES, C.J.; LIMPAPHAYOM, K.K.; HOLINKA, C.F.; AUSMANAS, M.K. Relief of vasomotor symptoms and vaginal atrophy with three doses of conjugated estrogens and medroxyprogesterone acetate in postmenopausal Asian women from 11 countries: The Pan-Asia menopause (PAM) study. Maturitas, Amsterdam, v, 52, n. 1, p. $35-51$, sep. 2005.

TANSEY, G.; HUGHES Jr., C.L.; CLINE, M.; KRÜMMER, A.; WALMER, D.K.; SCHMOLTZER, S. Effects of dietary soybean estrogens on the reproductive tract in female rats. Proc. Soc. Exp. Biol. Med., Malden, v. 217, n. 3, p. 340 - 344, mar. 1998.

THAM, D.M.; GARDNER, C.D.; HASKELL, W.L. Potential health benefits of dietary phytoestrogens: a review of the clinical, epidemiological, and mechanistic evidence. $J$ Clin Endocrinol Metab., Springfield, v. 83, n. 7, p. 2223 - 2235, jul. 1998.

THE BETHESDA SYSTEM FOR REPORTING CERVICAL VAGINAL CYTOLOGIC DIAGNOSES. Acta Cytol., Chicago, v. 37, n. 2, p. 115 - 124, 1993.

THOMPSON, P.D.; BUCHNER, D.; PINA, I.L.; BALADY, G.J.; WILLIAMS, M.A.; MARCUS, B.H.; BERRA, K.; BLAIR, S.N.; COSTA, F.; FRANKLIN, B.; FLETCHER, G.F.; GORDON, N.F.; PATE, R.R.; RODRIGUEZ, B.L.; YANCEY, A.K.; WENGER, N.K. Exercise and physical activity in the prevention and treatment of atherosclerotic cardiovascular disease: a statement from the Council on Clinical Cardiology (Subcommittee on Exercise, Rehabilitation, and Prevention) and the Council on Nutrition, Physical Activity, and Metabolism (Subcommittee on Physical Activity). Circulation, Dallas, v. 107, n. 24, p. 3109 - 3116, jun. 2003.

THOMAS, A.; CORREA, M.M.; KUMAR, K.R. Clinical profile and cervical cytomorphology in symptomatic postmenopausal women. Indian J. Pathol. Microbiol., Chandigarh, v. 46, n. 2, p. $176-179$, apr. 2003.

TORTORA, G.J.; GRABOWSKI, S.R. Corpo Humano: Fundamentos de anatomia e fisiologia. 6 ed. Porto Alegre: Artmed, 2006.

TRIOLA, M.F. Introdução à estatística. 9 ed. Rio de Janeiro: LTC, 2005.

UESUGI, T.; TODA, T.; OKUHIRA, T.; CHEN, T. Evidence of estrogenic effect by the Three-month-intervention of isoflavone on vaginal maturation and bone metabolism in early postmenopausal women. Endocr. J., Tokyo, v. 50, n. 5, p. 613 - 619, oct. 2003.

UNFER, V.; CASINI, M.L.; COSTABILE, L.; MIGNOSA, M. ; GERLI, S. ; Di RENZO, G.C. Endometrial effects of long-term treatment with phytoestrogens: a randomized, double-blind, placebo-controlled study. Fertil. Steril., New York, v. 82, n. 1, p. 145 148, jul. 2004. 
Van Der LAAK, J.A; de BIE, L.M.; de LEEUW, H.; de WILDE, P.C. ; HANSELAAR, A.G. The effect of Replens on vaginal cytology in the treatment of postmenopausal atrophy: cytomorphology versus computerised cytometry. J. Clin. Pathol., London, v. 55, n. 6, p. $446-451$, jun. 2002.

WANG, W.; TANAKA, Y.; HAN, Z.; HIGUCHI, C.M. Proliferative response of mammary glandular tissue to formononetin. Nutr. Cancer, Philadelphia, v. 23, n. 2, p. 131 - 140, 1995.

WARREN, M.P.; SHORTLE, B.; DOMINGUES, J.E. Use of alternative therapies in menopause. Best. Pract. Res. Clin. Obstet. Gynaecol., London, v. 16, n. 3, p. 411 448, jun. 2002.

WIED, L.G.; BIBBO, M. Hormonal Cytology. In: Comprehensive Cutopathology. W.B. Saunders Company, p. 85 - 114, 1991.

WILCOX, G.; WAHLQVIST, M.L.; BURGER, H.G.; MEDLEY, G. Oestrogenic effects of plant foods in postmenopausal women. BMJ., London, v. 301, n. 6757, p. $905-$ 906, oct. 1990.

WONG, C.K.; KEUNG, W.M. Bovine adrenal 3beta-hydroxysteroid dehydrogenase (E.C. 1.1.1. 145)/5-ene-4-ene isomerase (E.C. 5.3.3.1): characterization and its inhibition by isoflavones. J. Steroid. Biochem. Mol. Biol., Oxford, v. 71, n. 5 - 6, p. 191 - 202, dez. 1999.

WOOD, C.E.; KAPLAN, J.R.; STUTE, P.; CLINE, J.M. Effects of soy on the mammary glands of premenopausal female monkeys. Fertil. Steril., New York, v. 85, suppl. 1, p. 1179 - 1186, apr. 2006.

WRITING GROUP FOR THE WOMEN'S HEALTH INITIATIVE INVESTIGATORS. RISKS AND BENEFITS OF ESTROGEN PLUS IN HEALTHY POSTMENOPAUSAL WOMEN. JAMA, Chicago, v. 288, p. 366 - 368, 2002.

XU, X.; DUNCAN, A.M.; WANGEN, K.E.; KURZER, M.S. Soy consumption alters endogenous estrogen metabolism in postmenopausal women. Cancer Epidemiol. Biomarkers Prev., Philadelphia, v. 9, n. 8, p. 781 - 786, aug. 2000.

YILDIRIM, B.; KALELI, B.; DÜZCAN, E.; TOPUZ, O. The effects os postmenopausal vitamin D treatment on vaginal atrophy. Maturitas, Amsterdam, v. 49, n. 4, dec. 2004.

Zur HAUSEN, H. Papillomaviruses causing cancer: evasion from host-cell control in early events in carcinogenesis. J. Natl. Cancer Inst., Bethesda, v. 92, n. 9, p. $690-$ 698, may. 2000. 


\section{ANEXOS}

\section{Anexo I - Parecer do Comitê de Ética em Pesquisa do Centro de Saúde Escola de Medicina de Ribeirão Preto da Universidade de São Paulo.}

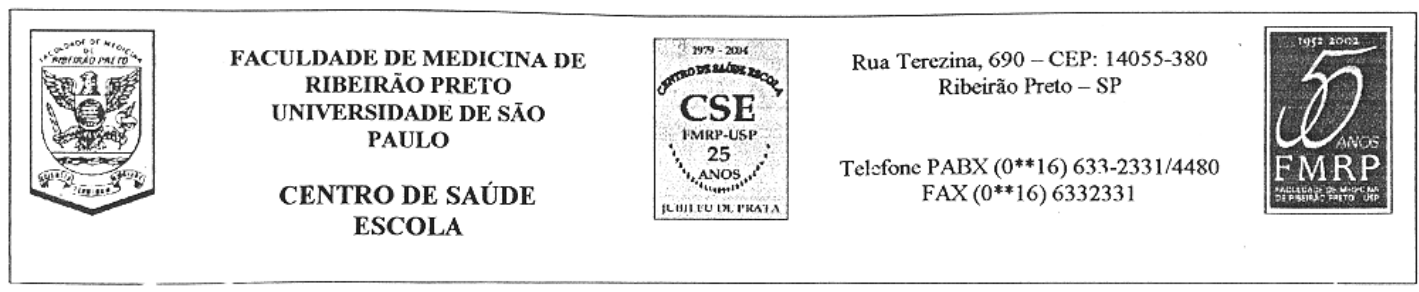

Comitê de Ética em Pesquisa do Centro de Saúde Escola da Faculdade de Medicina de Ribeirão Preto da Universidade de São Paulo

OF. $N^{o} .222 / 05 / C O O R D . C E P / C S E-F M R P-U ̈ S P .20 / 4 / 2005$.

Senhora Professora,

Vimos na presente oportunidade comunicar que o Comitê de Ética em Pesquisa do Centro de Saúde Escola da Faculdade de Medicina de Ribeirão Préto da Universidade de São Paulo, em sua $38^{\mathrm{a}}$ reunião ordinária, realizada em 19 de abril de 2005, analisou e apreciou o parecer do Senhor Relator, referente ao Projeto de Pesquisa: "Avaliação do efeito estrogênico da isoflavona na maturação do epitélio vaginal de mulheres em peri e pós menopausa", protocolo:0149/CEP/CSE-FMRP-USP, que será coordenado por V.S , pelo Médico Ginecologista Dr. Silvio Antonio Franceschini e pela orientanda Edna Talarico Rodrigues, foi aprovacio. Porém, solicitamos que faça uma justificativa por que serão excluídas do estudo, as muiheres de origem asiática e as mulheres com hábito vegetariano.

Lembramos que em atendimento à Resolução 196/96, deverá ser encaminhado a este CEP o relatório final da pesquisa e a publicação de seus resultados.

Sendo o que tínhamos para o momento, despedimo-nos.

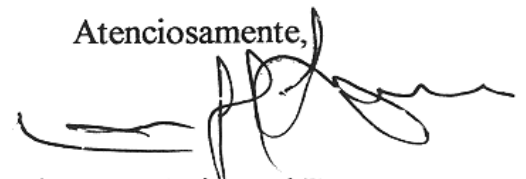

Prof ${ }^{\circ}$.Dr. Laércio Joel Franco

Coordenador do CEP/CSE-FMRP-USP

Ilma. Sra.

Prof ${ }^{a}$. Dra. Maria Regina Torqueti Toloi

Faculdade de Ciências Farmacêuticas de Ribeirão Preto-USP. 


\section{Anexo II - Documento apresentado ao CSE-Cuiabá da FMRP-USP para obtenção da aprovação do Comitê de Ética em Pesquisa}

Faculdade de Ciências Farmacêuticas de Ribeirão Preto - USP / SP

\section{TERMO DE CONSENTIMENTO LIVRE E ESCLARECIDO}

(Obrigatório para Pesquisa Clínica em Seres Humanos - Resolução nº 196 de

$$
\text { 10/10/1996 - CNS) }
$$

\section{DADOS DE IDENTIFICAÇÃO DO PACIENTE OU RESPONSÁVEL LEGAL}

NOME DA PACIENTE

DOCUMENTO DE IDENTIDADE No

DATA DE NASCIMENTO

ENDEREÇO

$\mathrm{N}^{\mathrm{O}}$.......

COMPLEMENTO.

CEP

CIDADE. ESTADO TELEFONE

\section{DADOS SOBRE O ESTUDO}

TÍTULO: "AVALIAÇÃO DO EFEITO ESTROGÊNICO DA ISOFLAVONA NA MATURAÇÃO DO EPITÉLIO VAGINAL DE MULHERES EM PERI E PÓS MENOPAUSA"

PESQUISADORES RESPONSÁVEIS PRINCIPAIS:

RESPONSÁVEIS CLÍNICOS: Dr. Sílvio Antonio Franceschini.

COORDENADOR DO PROJETO: Profa. Dra. Maria Regina Torqueti Toloi

Departamento de Análises Clínicas, Toxicológicas e Bromatológicas da FCFRP-USP

INÍCIO DO ESTUDO EM 01/2005

DURAÇÃO: 15 meses

\section{EXPLICAÇÕES DO PESQUISADOR AO PACIENTE OU SEU REPRESENTANTE LEGAL}

\section{PACIENTES DO GRUPO CONTROLE}

1. Esclarecimentos à paciente: Mulheres na idade de 45 a 50 anos começam a apresentar sintomas da diminuição dos hormônios produzidos pelos ovários através de alterações no ciclo menstrual caracterizado por mudanças no intervalo e fluxo menstrual. Este período é chamado climatério. Quando ocorre a parada definitiva da menstruação, tem-se o que chamamos de menopausa. Os sintomas mais comumente apresentados nestes períodos são: ondas de calor, falta de sono, 
irritabilidade, perda de memória, ressecamento da vagina e/ou perda do prazer na prática sexual, flacidez da pele, perda de urina e outros menos freqüentes. Estes sintomas podem ser combatidos pela reposição hormonal, ou seja, a paciente assistida pelo seu ginecologista, se estiver apta, poderá receber tratamento para combater os sintomas descritos da menopausa. Neste estudo selecionaremos 3 grupos de pacientes: 20 mulheres que tomarão a isoflavona na dose de $40 \mathrm{mg} / \mathrm{dia}$. Como controle desta pesquisa teremos mais dois grupos de pacientes, um deles chamado grupo placebo e outro grupo controle. No grupo placebo, 20 pacientes deverão ingerir $40 \mathrm{mg}$ de caseína, uma proteína do leite, que sabemos não ter efeito algum para combater os males da menopausa. Por outro lado, o grupo controle será constituído por 20 pacientes que mesmo conhecendo os sintomas da menopausa, optaram por não tomar nenhum medicamento. Este documento está sendo dirigido apenas às pacientes que farão parte do grupo controle. As pacientes deste grupo deverão colher citologia vaginal ou também como é conhecida, lâmina de Papanicolaou, pelo médico ginecologista. Este procedimento será repetido após 24 semanas de tratamento. Neste trabalho de pesquisa temos como objetivo investigar se o medicamento isoflavona, que é extraído da soja, protege a mulher dos sintomas que a menopausa traz.

2. Justificativa e Objetivo da Pesquisa: $O$ objetivo deste projeto é avaliar se o tratamento com isoflavona melhora a secura vaginal, trazendo com isto uma melhoria na prática sexual em mulheres na peri e pós menopausa e se a paciente refere melhora dos sintomas indesejáveis da menopausa, com o tratamento.

3. Procedimentos que serão utilizados e propósitos: Duas lâminas de citologia vaginal serão colhidas no momento do exame ginecológico. Uma delas será encaminhada segundo a rotina já estabelecida pelo Centro de Saúde Escola Cuiabá, a outra lâmina fará parte deste estudo e será encaminhada ao laboratório de Citologia Clínica da Faculdade de Ciências Farmacêuticas de Ribeirão Preto - USP. Caso a paciente apresente alguma feridinha no colo do útero, um fragmento será retirado durante uma micro cirurgia. Neste caso, a biópsia será encaminhada de acordo com a rotina já estabelecida pelo Centro de Saúde Escola Cuiabá, cujo resultado será afixado no prontuário médico da paciente em questão.

4. Complicações e riscos esperados: As pacientes devem estar cientes que ao optarem por não fazer uso de nenhum medicamento para reposição hormonal podem apresentar complicações, como aumento das gorduras do sangue e com isso aumento do risco de infarto, trombose e derrame cerebral; além de apresentarem os sintomas já citados da menopausa. Com relação à lâmina de Papanicolaou deste estudo não haverá prejuízo algum, pois este procedimento é utilizado em qualquer exame ginecológico; caso seja necessária a coleta de um fragmento do colo uterino, a mesma não constitui risco maior que o assumido no consentimento do ato cirúrgico, pois utilizaremos um fragmento pequeno da peça cirúrgica que em nada prejudica o diagnóstico nem o tratamento. Todas as informações fornecidas pela paciente ao estudo serão consideradas absolutamente confidenciais. O seu nome e os resultados dos exames obtidos com suas amostras são de interesse apenas nesta pesquisa.

Todas as informações que as pacientes desejarem saber serão fornecidas. Se a paciente resolver desistir de participar como voluntária deste trabalho ela poderá fazê-lo a qualquer momento sem constrangimento ou punição, ou deixar de ter a assistência médica que a mesma tem direito. Nós pesquisadores estamos nos comprometendo a manter o sigilo profissional dos resultados obtidos desta pesquisa, mesmo quando da publicação dos resultados, a identidade da paciente nunca será divulgada. As informações obtidas serão estritamente confidenciais.

5. Benefícios obtidos: A participação neste estudo trará como benefícios acompanhamento médico, realizações de exames, monitoramento durante todo o estudo. Não haverá necessidade de repasse de despesas com transporte e alimentação, visto que, a paciente, voluntária, estará sendo selecionada no momento de sua consulta médica de rotina ao ginecologista.

6. Compromisso: A equipe desta pesquisa se compromete em divulgar os resultados da mesma sejam eles positivos ou não.

\section{QUESTIONÁRIO. RESPONDA POR FAVOR:}


a) Fui esclarecida sobre a garantia de receber resposta a qualquer pergunta ou esclarecimento acerca dos procedimentos, riscos, benefícios e outros assuntos relacionados com a pesquisa e o tratamento do paciente?

SIM

\section{NÃO}

b) Fui esclarecida sobre a liberdade de retirar o meu consentimento a qualquer momento, sem que isso traga prejuízo quanto à continuidade do meu tratamento ou qualquer outro atendimento médico neste serviço?

SIM

NÃO

c) Fui esclarecida de que não haverá remuneração financeira para a minha inclusão no estudo? SIM

NÃO

d) Fui esclarecida de que não haverá indenização além das previstas pela lei, em reparação a dano imediato aos envolvidos no estudo?

SIM

NÃO

e) Fui esclarecida sobre a segurança de que minha identidade será preservada, mantendo-se todas as informações em caráter confidencial?

SIM

NÃO

f) Estou ciente de que os resultados desta pesquisa sejam eles favoráveis ou não serão tornados públicos, sujeitos a publicações científicas?

SIM

NÃO

g) Fui esclarecida quanto aos benefícios e riscos deste tratamento e neste momento estou dando meu consentimento para participar dele como voluntária.

SIM

NÃO

\section{CONSENTIMENTO PÓS-INFORMADO}

(Obrigatório para Pesquisa Clínica em Seres Humanos - Resolução no 196 de 10/10/1996 - CNS)

Declaro que, após ter sido devidamente esclarecida sobre o projeto de pesquisa acima e informada sobre os riscos e benefícios deste estudo, consinto em participar, na qualidade de paciente, deste Projeto de Pesquisa.

Ribeirão Preto, de de

Assinatura do paciente ou Responsável Legal
Assinatura do médico que obteve o consentimento (carimbo ou nome legível com CRM)

Tel contato: 633 2331, ramal 227 
Anexo III - Questionário referente ao projeto: "Avaliação do efeito estrogênico da isoflavona na maturação do epitélio vaginal de mulheres em peri e pós menopausa"

NOME:

ENDEREÇO: Rua/Av. №:

Complemento: Bairro:

Cidade: Estado: Telefone:

IDADE: ESTADO CIVIL: solteira casada viúva amigada

COR DA PELE: Branca Não Branca

\section{1) SINTOMAS GERAIS DA MENOPAUSA}

Assinale quais os sintomas da menopausa que você sente atualmente e sua intensidade/freqüência

a) Ondas de calor: ( )sim ( )não

Intensidade: ( ) leve ( ) moderada ( ) acentuada

Freqüência: ( ) raramente ( ) freqüentemente ( ) sempre

Quantidade de ocorrências por dia (em números):

b) Suores noturnos: ( ) sim （ )não

Intensidade: ( ) leve ( ) moderada ( ) acentuada

Freqüência: ( ) raramente ( ) freqüentemente ( ) sempre

c) Palpitação: ( )sim （ )não

Intensidade: ( ) leve ( ) moderada ( ) acentuada

Freqüência: ( ) raramente ( ) freqüentemente ( ) sempre

d) Dor de Cabeça: ( )sim ( )não

Intensidade: ( ) leve ( ) moderada ( ) acentuada

Freqüência: ( ) raramente ( ) freqüentemente ( ) sempre

e) Insônia: ( )sim （ )não

Intensidade: ( ) leve ( ) moderada ( ) acentuada

Freqüência: ( ) raramente ( ) freqüentemente ( ) sempre

f)Depressão / oscilação de humor (euforia/tristeza): ( )sim （ )não

Intensidade: ( ) leve ( ) moderada ( ) acentuada

Freqüência: ( ) raramente ( ) freqüentemente ( ) sempre 
g) Cansaço / fraqueza muscular: ( ) sim ( )não

Intensidade: ( ) leve ( ) moderada ( ) acentuada

Freqüência: ( ) raramente ( ) freqüentemente ( ) sempre

h) Perda de memória / distração / desconcentração: ( ) $\operatorname{sim}$ ( )não Intensidade: ( ) leve ( ) moderada ( ) acentuada

Freqüência: ( ) raramente ( ) freqüentemente ( ) sempre

i) Irritabilidade / Nervoso / Ansiedade: ( ) sim （ )não

Intensidade: ( ) leve ( ) moderada ( ) acentuada

Freqüência: ( ) raramente ( ) freqüentemente ( ) sempre

j) Incontinência urinária: ( ) sim ( )não

Intensidade: ( ) leve ( ) moderada ( ) acentuada

Freqüência: ( ) raramente ( ) freqüentemente ( ) sempre

k) Perda da Libido: ( ) sim ( )não

Intensidade: ( ) leve ( ) moderada ( ) acentuada

Freqüência: ( ) raramente ( ) freqüentemente ( ) sempre

l) Dispareunia: ( )sim ( )não

Intensidade: ( ) leve ( ) moderada ( ) acentuada

Freqüência: ( ) raramente ( ) freqüentemente ( ) sempre

m) Ressecamento vaginal: ( ) sim （ )não

Intensidade: ( ) leve ( ) moderada ( ) acentuada

Freqüência: ( ) raramente ( ) freqüentemente ( ) sempre

n) Pele do corpo flácida ou ressecada: ( ) $\operatorname{sim} \quad($ )não

Intensidade: ( ) leve ( ) moderada ( ) acentuada

Freqüência: ( ) raramente ( ) freqüentemente ( ) sempre

\section{2) REPOSIÇÃO HORMONAL}

Você já se submeteu a algum tipo de terapia de reposição hormonal anteriormente?

Qual?

Quando?

Por quanto tempo?

Você desistiu do tratamento?

Qual o motivo da desistência? 


\section{3) VIDA SEXUAL}

Qual a data da última menstruação e/ou Início da menopausa

Qual a idade da primeira menstruação

Com quantos anos teve sua primeira relação sexual com penetração vaginal?

Quantos parceiros teve ao longo de sua vida sexualmente ativa?

Quantos parceiros teve nos últimos 5 anos?

Quantos parceiros teve nos últimos 6 meses?

Qual o tipo de parceiro? ( ) fixo ( ) casual ( ) nenhum

Você já teve alguma doença sexualmente transmissível?

Qual (s)?

E seu parceiro?

Qual (s)?

Já fez ou faz algum tipo de tratamento para doença sexualmente transmissível?

Qual o medicamento utilizado?

A quanto tempo?

Já fez cauterização e/ou biópsia?

Qual o método anticoncepcional utilizado ao longo da vida reprodutiva?
( )Contraceptivos orais
( )Preservativos
( ) DIU
( ) Outros

Você utiliza ou utilizava preservativos?

Quais os medicamentos que você utiliza atualmete especifique? 


\section{Anexo IV - REQUISIÇÃO DE COLPOCITOLOGIA}

\begin{tabular}{|c|c|c|c|}
\hline NOME : & & & \\
\hline Idade: & Data nascimento & Sexo: & Cor: \\
\hline Estado Civil & Gestação & Parto : & Aborto \\
\hline última menst & Dia do cicl & & Ciclo: \\
\hline
\end{tabular}

MOTIVO DA CONSULTA:

\begin{tabular}{|c|c|c|c|}
\hline \multicolumn{3}{|l|}{ EXAMES ANTERIORES : } \\
\hline Biópsia & Citologia & Outros & Resultado: \\
\hline
\end{tabular}

\begin{tabular}{|l|l|l|l|}
\hline \multicolumn{5}{|l|}{ EM USO DE : } \\
\hline DIU & Anovulatório & Hormônio & Quimioterápico \\
\hline Outros & \multicolumn{2}{|l|}{ Fixar tipo, dose : } \\
\hline
\end{tabular}

\section{TRATAMENTOS REALIZADOS :}

\begin{tabular}{|l|l|l|l|l|}
\hline \multicolumn{4}{|l|}{ MATERIAL DE ORIGEM : } \\
\hline Vaginal & Cervical & Endocervical & Endometrial & Outros \\
\hline
\end{tabular}

\begin{tabular}{|c|c|}
\hline EXAME GINECOLÓGICO & Esquema do colo do útero: \\
\hline & \\
\hline IMPRESSÃO DIAGNÓSTICA & \\
\hline & \\
\hline & \\
\hline & \\
\hline
\end{tabular}

\section{LOCAL:}

TELEFONE:

MÉDICO (Assinatura / Carimbo ) :

COLHIDO DIA: 
COLPOCITOLOGIA - RESULTADO

\begin{tabular}{|l|l|l|}
\hline Resultado em: & Enviado em: & Exame $\mathbf{n}^{\circ}$ : \\
\hline
\end{tabular}

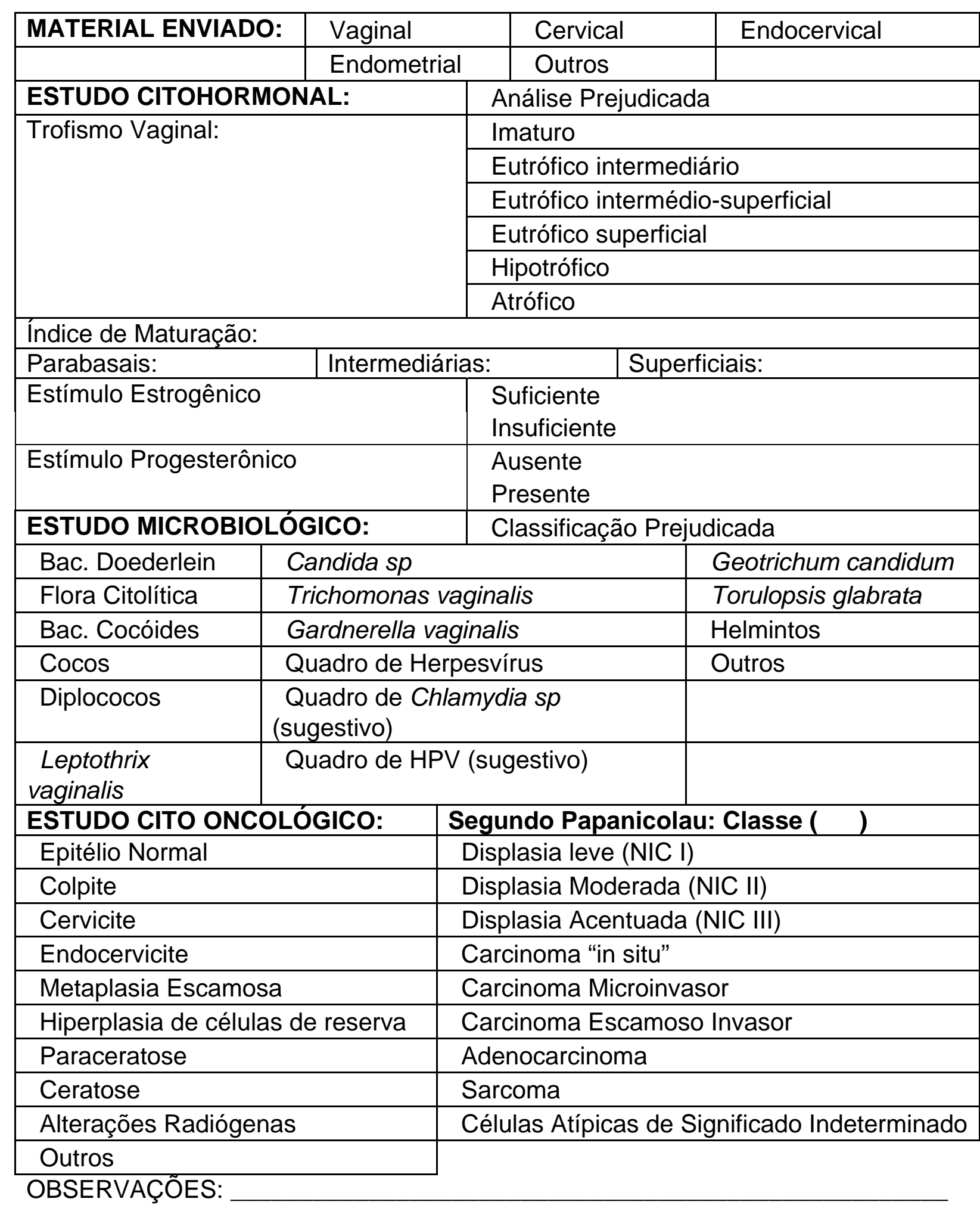

DATA:

Responsável 


\section{ANEXO V - INDICE DE KUPPERMANN}

\section{QUESTIONÁRIO SOBRE AS QUEIXAS CLÍNICAS}

Paciente $\mathbf{n}^{\circ}$

\begin{tabular}{|c|l|l|l|l|l|l|l|}
\hline $\begin{array}{c}\text { Queixas } \\
\text { clínicas }\end{array}$ & $\begin{array}{c}\text { Tempo } \\
\text { controle }\end{array}$ & $\mathbf{1}^{\mathbf{0}}$ mês & $\mathbf{2}^{\mathbf{0}}$ mês & $\mathbf{3}^{\mathbf{0}}$ mês & $\mathbf{4}^{\mathbf{0}}$ mês & $\mathbf{5}^{\mathbf{0}}$ mês & $\mathbf{6}^{\mathbf{0}}$ mês \\
\hline $\begin{array}{c}\text { Ondas de } \\
\text { calor }\end{array}$ & & & & & & & \\
\hline Sudorese & & & & & & & \\
\hline Palpitação & & & & & & & \\
\hline Melancolia & & & & & & & \\
\hline Tonturas & & & & & & & \\
\hline Zumbido & & & & & & & \\
\hline Iritabilidade & & & & & & & \\
\hline Ansiedade & & & & & & & \\
\hline Depressão & & & & & & & \\
\hline Insônia & & & & & & & \\
\hline $\begin{array}{c}\text { Diminuição } \\
\text { da libido }\end{array}$ & & & & & & & \\
\hline Amnésia & & & & & & \\
\hline $\begin{array}{c}\text { Fadiga } \\
\text { mental }\end{array}$ & & & & & & & \\
\hline Mialgia & & & & & & & \\
\hline Artralgia & & & & & & & \\
\hline Neuralgia & & & & & & & \\
\hline Dispaurenia & & & & & & & \\
\hline Sinusorragia & & & & & & & \\
\hline $\begin{array}{c}\text { Dor } \\
\text { miccional }\end{array}$ & & & & & & & \\
\hline $\begin{array}{c}\text { Incontinência } \\
\text { urinária }\end{array}$ & & & & & & & \\
\hline Dor lombar & & & & & & & \\
\hline $\begin{array}{c}\text { Dist. } \\
\text { menstrual }\end{array}$ & & & & & & & \\
\hline $\begin{array}{c}\text { Dor baixo } \\
\text { ventre }\end{array}$ & & & & & & & \\
\hline Cefaléia & & & & & & & \\
\hline $\begin{array}{c}\text { Total } \\
\text { Total }\end{array}$ & & & & & & \\
\hline
\end{tabular}

0 - ausente; 1 - leve; 2 - moderada; 3 - intensa

*Freqüências de ondas de calor/dia: $1 \rightarrow$ leve; 2 a $5 \rightarrow$ moderada; mais que $5 \rightarrow$ intensa. 